AVALIAÇÃO IN VITRO DA MICROINFILTRAÇÃO MARGINAL EM RESTAURAÇÕES CLASSE II, CONFECCIONADAS COM UM CIMENTO DE IONÔMERO DE VIDRO MODIFICADO POR RESINA, UMA RESINA COMPOSTA "SEMICONDENSÁVEL" E UMA RESINA COMPOSTA “CONDENSÁVEL"

MARIA FERNANDA BORRO BIJELLA

Dissertação apresentada à Faculdade de Odontologia de Bauru, da Universidade de São Paulo, como parte dos requisitos para obtenção do título de Mestre em Odontologia, área de Odontopediatria. 
AVALIAÇÃO IN VITRO DA MICROINFILTRAÇÃO MARGINAL EM RESTAURAÇÕES CLASSE II, CONFECCIONADAS COM UM CIMENTO DE IONÔMERO DE VIDRO MODIFICADO POR RESINA, UMA RESINA COMPOSTA “SEMICONDENSÁVEL" E UMA RESINA COMPOSTA “CONDENSÁVEL"

MARIA FERNANDA BORRO BIJELLA

Dissertação apresentada à Faculdade de Odontologia de Bauru, da Universidade de São Paulo, como parte dos requisitos para obtenção do título de Mestre em Odontologia, área de Odontopediatria.

(Edição Revisada)

Orientadora: Prof. $^{a}$ Dr. $^{\text {a }}$ Maria Francisca Thereza Borro Bijella

Bauru 


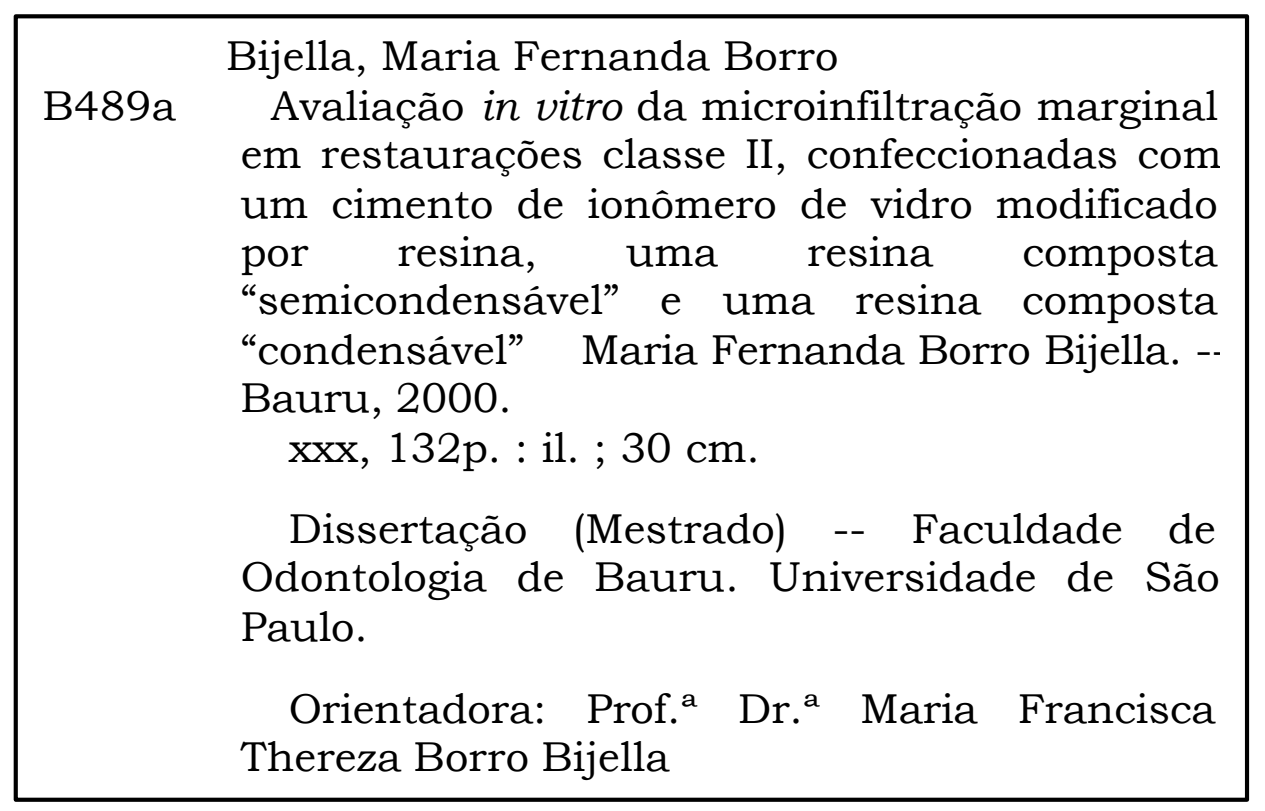

Autorizo, exclusivamente para fins acadêmicos e científicos, a reprodução total ou parcial desta dissertação, por processos fotocopiadores e ou meios eletrônicos.

Assinatura da autora:

Data: 


\section{Dados Pessoais}




\section{MARIA FERNANDA BORRO BIJELLA}

2 de outubro de 1975

Bauru - SP

Filiação

$1994-1997$

$1995-1996$

$1998-2000$

Associações
Nascimento

Vitoriano Truvijo Bijella

Maria Francisca Thereza Borro

Bijella

Curso de Graduação em Odontologia - Universidade do Sagrado Coração - Bauru.

Bolsista do PIBIC/CNPq.

Curso de Pós-Graduação em Odontologia ao nível de Mestrado, Área de Odontopediatria -

Faculdade de Odontologia de Bauru

- Universidade de São Paulo.

ABOPREV - Associação Brasileira de Odontologia de Promoção de Saúde. APCD - Associação Paulista de Cirurgiões Dentistas.

GRUPO - Grupo Brasileiro de Professores de Odontopediatria e Ortodontia.

IADR - International Association

Dental Research.

SBPqO - Sociedade Brasileira de Pesquisas Odontológicas. 
"Eupedi PFonca...

- Deus me deu dificuldades para me faren forte. Eu pedi Sabedonia...

e Deus me deu Problemas para vesolven.

Eu pedi Prosperidade...

- Deus me deu Céveloro e Músculos para trabathar. Eu pedi Cosagem...

e Deus me deu Pexigo para supenax.

Eu pedi eAlmox...

- Deus me deu pessoas com Problemas para ajudar.

Eu pedi OFavores...

e Deus me deu Opontunidades.

Eu não vecebi nada do que pedi...

ollas en recebi tudo de que precisana." 


\section{Dedicatória}




\section{Elgradeco Dedico este OTrabalho:}

Aos meus pais, Witoriano e Maxia OFrancisca, em reconhecimento de tantas renúncias a si mesmos em favor de minha educação.

Por mais belas e sinceras que sejam as palavras ditas, serão sempre insuficientes para traduzir meus sentimentos em relação a vocês.

Em especial à minha mãe PProf. $_{\text {. Dx. }}$ ' Mlaxia Francisca OThexera Bowso Byjella, minha ETERNA orientadora! Você é exemplo de honestidade, dedicação, força e humildade. Obrigada pela confiança em mim depositada e sobretudo pela maneira simples e paciente com que me apoiou nos momentos dificeis de minha escolha pela Odontopediatria. Minha admiração por suas atitudes e comportamentos torna-se referência de vida!

"Dề um peiaxe a um homem faminto e você o alimentaxá pox um dia. Ensine-o a pescax e você o estavá alimentando pelo vesto da vida."

Provérbio Chinês 
Agradecimentos 
A Deus, por estar ao meu lado nos bons momentos e me sustentar nos momentos dificeis, dando-me força e perseverança de continuar no bom caminho, mesmo quando os obstáculos parecem intransponiveis. 


\begin{abstract}
A meu irmão Ricando, pelo carinho, dedicação e por estar sempre presente nos momentos importantes de minha vida, valorizando minhas conquistas.
\end{abstract}

Ao Fábio por seu companheirismo, incentivo e até mesmo auxílio nos momentos difíceis. Agradeço por ter tido paciência e compreensão, ajudando-me a alcançar mais um objetivo...

\title{
eAma Yocế!
}

"O imico lugar no mundo onde o sucesso vem antes do trabaltho é no dicionáario"
Widal OPasson 


\section{OMeu OAgradecimento Especial:}

Aos meus $\mathscr{T}_{i o s}$ e Primos, em especial à OFia

Carmo, pelos laços que nos unem e por me

apoiarem mesmo que de longe.

Aos meus futuros sogros, Clavia Luicia e CVivaldo, e cunhados, pelo carinho com que me acolheram em sua família.

"OAs pessoas que vencem neste mundo são as que procurame as circunstancias de que precisame, quando não as encontram, as criam". Bornard OHaw 
À Cecilia, minha futura cunhada, por seu jeito meigo, sempre torcendo pelo meu sucesso.

À minha colega de Mestrado, Maxina, por entender e transmitir o exato significado da palavra amizade. Ajudando-me muitas vezes, como uma mãe.

À Patricia e Cadu, Paula e Éduardo, Livia e Slauber pela amizade e por todos os momentos agradáveis que passamos juntos.

Difluil querer definir amigo.

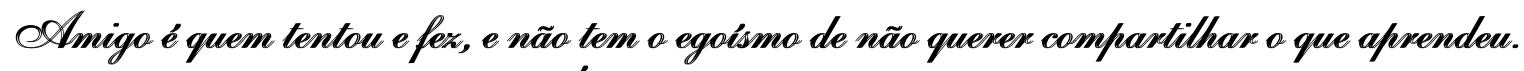
C̈́ aquele que entende seu desigo de vour, a sede pelo 'pror virr'.

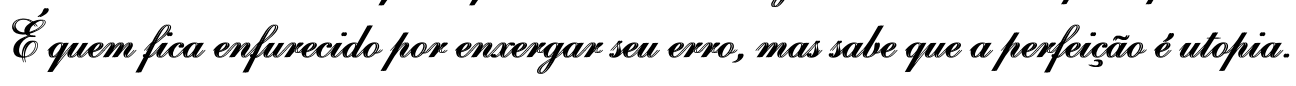
OAmigo épra sempire, mesmo que o sempire ñ̃o exista." Chnônimo 
EAgradega etinda:

Aos docentes da Disciplina de Odontopediatria da Faculdade de Odontologia de Bauru - USP, PProf.s $_{\text {Dx.s }}$ OAymax PPavaxini; Bennasdo Gonnáler Wono, Gosé Eduardo de Oliveina Lima,

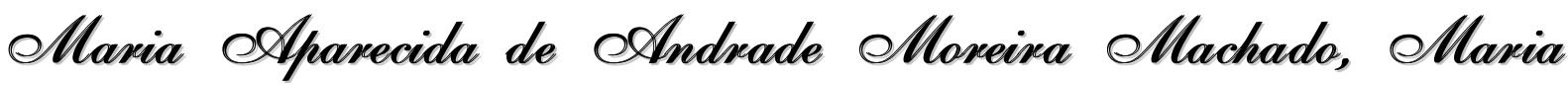
Francisca OThevera Borso Byjella, Ruy Cesax Camango OAbdo, Oalete Olloura Bonifácio da OPilva.

Aos colegas do curso de Mestrado OAdriano, OAna Carla, OAna Luisa, Cleide, Daniela, Livia, Ollavina, Paloma e Patricia, pelos bons momentos e inúmeros obstáculos superados na busca deste objetivo.

Aos funcionários da Disciplina de Odontopediatria "Doma" Lia, Wilma, Lilian, Estela, Fatima, OKelly e Paulo, pela amizade, carinho e colaboração em todos os momentos.

À Uliversidade do Pagrado Coxação, pela minha formação. 
À Fraculdade de Odontologia de $\mathscr{B}$ aumu da Olniversidade de Ôão Paulo, na pessoa de seu Diretor, $\mathscr{P}_{\text {rof. }} \mathscr{D}_{\boldsymbol{x}}$. OAymax $\mathscr{P}_{\text {avarini, }}$ pela recepção.

Ao $\mathscr{P}_{r o f .} \mathscr{D}_{x}$ Luis $\mathscr{F}_{\text {ernando }} \mathscr{P}_{\text {egonaro, }}$ Presidente da Comissão de Pós-Graduação, pelas oportunidades concedidas.

Ao Prof. Dx. Losé Robento Pexcira Lauris, pelos ensinamentos e colaboração na análise estatística dos resultados.

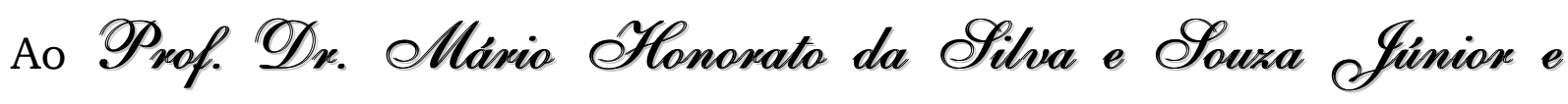
Prof. Dr. Ricardo Ollaxins de Cavvalho, pela cordialidade, ajuda e presteza com que me auxiliaram no desenvolvimento deste trabalho.

A Profa. Alna Pisginia, que carinhosamente realizou a correção gramatical desta dissertação.

Ao OMaxcelo (Biblioteca) pela ajuda na formatação deste trabalho.

Ao Daniel (Prefeitura do Campus) pela ajuda com o esquema da metodologia.

Aos Fruncionávios da $\mathscr{B}$ iblioteca pela atenção e constante orientação oferecida durante o desenvolvimento de minha dissertação. 
Aos funcionários ONelson (Dentística), Ovídio (Bioquímica) e Oaluadox pela atenção dispensada.

Às disciplinas de Dentistica e Bioquémica, pela cessão de suas dependências e equipamentos imprescindiveis para a realização deste trabalho.

A todos aqueles que, de alguma maneira, colaboraram e tornaram possivel a realização deste trabalho.

Mnito Obrigada! 
Sumário 


\section{SUMÁRIO}

LISTA DE FIGURAS ................................................

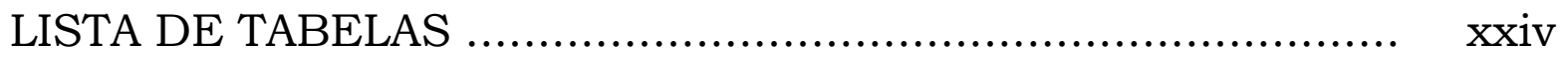

LISTA DE ABREVIATURAS E SÍMBOLOS.............................. xxvii

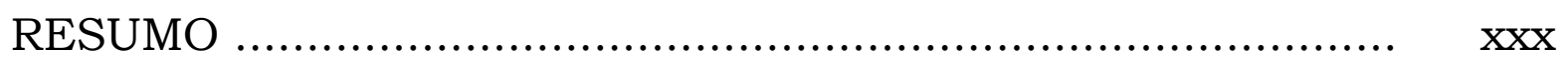

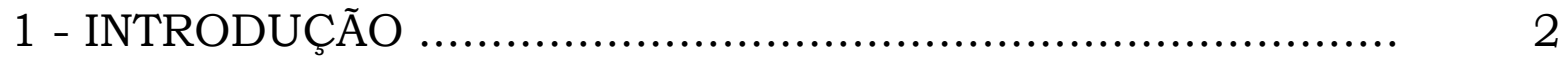

2 - REVISÃO DE LITERATURA .......................................... 9

3 - PROPOSIÇÃO ................................................... 64

4 - MATERIAL E MÉTODOS .............................................. 66

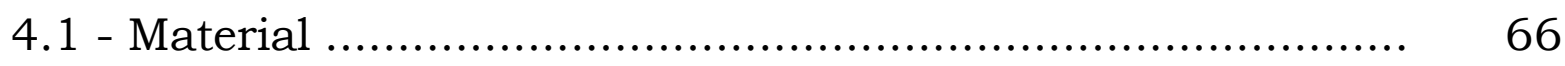

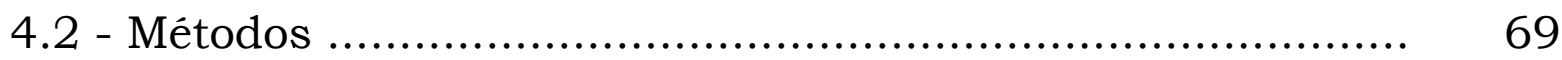

5 - RESULTADOS .......................................................... 83

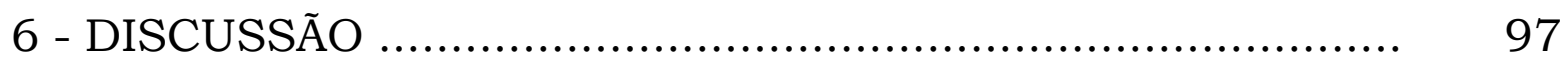

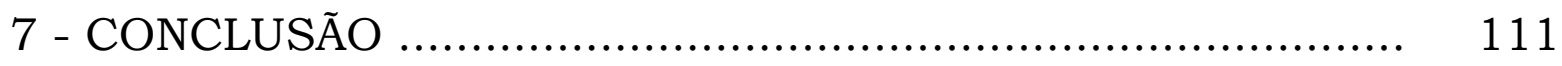

REFERÊNCIAS BIBLIOGRÁFICAS .................................. 114

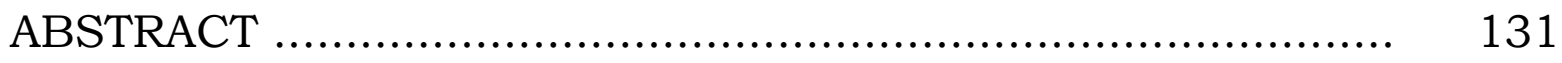




\section{Lista de Figuras}




\section{LISTA DE FIGURAS}

Figura 1: Cimento de ionômero de vidro modificado por resina VITREMER ${ }^{\mathrm{TM}}$. (GI) 67

Figura 2: Resina composta "semicondensável" ARISTON pHc. (GII) 67

Figura 3: Resina composta “condensável” Filtek ${ }^{\mathrm{TM}}$ P-60. (GIII) ..... 67

Figura 4: Quadro de relação de material utilizado, seguido de lote, fabricante e composição dos mesmos 68

Figura 5: Medidas utilizadas para a confecção das cavidades 70

Figura 6: Preparo terminado 71

Figura 7: Dentes incluídos em bloco de gesso, com matriz e cunhas posicionadas 72 
Figura 8: Máquina de corte com disco e dente posicionados para seccionamento 78

Figura 9: Esquema ilustrando aspecto das fatias obtidas dos espécimes 79

Figura 10: Exemplo da imagem capturada pelo scanner com paquímetro posicionado 80

Figura 11: Gráfico das médias das avaliações obtidas quando utilizados os máximos valores ou a média de valores dos três materiais testados nas condições de com ou sem ciclagem térmica 85

Figura 12: Aspecto do padrão da microinfiltração marginal da parede cervical apresentado pelo grupo I (Vitremer) com realização da termociclagem 90

Figura 13: Aspecto do padrão da microinfiltração marginal da parede cervical apresentado pelo grupo I (Vitremer) sem realização da termociclagem 
Figura 14: Aspecto do padrão da microinfiltração marginal da parede cervical apresentado pelo grupo III (P-60) com realização da termociclagem 92

Figura 15: Aspecto do padrão da microinfiltração marginal da parede cervical apresentado pelo grupo III (P-60) sem realização da termociclagem 93

Figura 16: Aspecto do padrão da microinfiltração marginal da parede cervical apresentado pelo grupo II (Ariston) com realização da termociclagem 94

Figura 17: Aspecto do padrão da microinfiltração marginal da parede cervical apresentado pelo grupo II (Ariston) sem realização da termociclagem ................................. 95 


\section{Lista de Tabelas}




\section{LISTA DE TABELAS}

Tabela 1: Número total de leituras realizadas nos 3 grupos de estudo, subdivididos em com e sem ciclagem térmica . 83

Tabela 2: Valores da média $(\bar{X})$ e desvio padrão (dp), da média das infiltrações ou máxima infiltração, obtidos dos três materiais testados, nas condições de com e sem ciclagem térmica, medidas em milímetros 84

Tabela 3: Parâmetros para o teste de Análise de variância a 2 critérios, utilizando-se a média dos valores de infiltração obtida para cada espécime 87

Tabela 4: Teste de Tukey, utilizando-se a média dos valores, para comparações múltiplas entre os materiais 87

Tabela 5: Parâmetros para o teste de Análise de variância a 2 critérios, utilizando-se o valor máximo de infiltração obtido para cada espécime 88 
Tabela 6: Teste de Tukey, utilizando-se o máximo valor, para comparações múltiplas entre os materiais 89 


\section{Lista de Abreviaturas e Simbolos}




\section{LISTA DE ABREVIATURAS E SÍMBOLOS}

Bis-EMA - Bisfeno A polietileno glicol dieter dimetacrilato

Bis-GMA - Bisfenil dimetacrilato

$\mathrm{Ca}^{++}-$íon cálcio

$\mathrm{cm}$ - centímetro

dp - desvio padrão

F - estatística F

$\mathrm{F}^{-}-$íon flúor

gl - graus de liberdade

$\mathrm{h}-$ horas

HEMA - hidróxietil metacrilato

$\mathrm{mm}$ - milímetro

MOD - mésio-ocluso-distal

$\mathrm{mW} / \mathrm{cm}^{2}-$ miliwatt por centímetro quadrado

$\mathrm{NaCl}$ - cloreto de sódio

$\mathrm{OH}^{-}$- ín hidroxila

p - probabilidade

$\mathrm{pH}$ - potencial hidrogeniônico

$\mathrm{pHc}-\mathrm{pH}$ controle

QM - quadrado médio

rpm - rotação por minuto 
s - segundos

TEGDMA - trietileno glicol dimetacrilato

UDMA - uretana dimetacrilato

${ }^{\circ} \mathrm{C}$ - graus Celsius

$\%$ - porcentagem

$\overline{\mathrm{X}}$ - média 


\section{RESUMO}

Avaliou-se in vitro a microinfiltração marginal em restaurações classe II, realizadas com o cimento de ionômero de vidro modificado por resina Vitremer, a resina composta "semicondensável" Ariston pHc e a resina composta "condensável" P-60, com o propósito de verificar a influência da ciclagem térmica para estes materiais, como também dois métodos de análise da penetração do corante. Para tanto, 60 prémolares, receberam cavidades classe II proximais, com a parede cervical localizada $1 \mathrm{~mm}$ abaixo da junção cemento-esmalte. Os espécimes foram divididos em 3 grupos de 20 dentes cada. O grupo I foi restaurado com Vitremer, o grupo II com Ariston pHc e o grupo III com P-60. Após a restauração, os espécimes foram acondicionados em recipientes plásticos com água deionizada por 24 horas a $37^{\circ} \mathrm{C}$. Decorrido esse período as restaurações receberam acabamento e polimento. Enquanto metade de cada grupo sofreu processo de termociclagem com 500 ciclos nas temperaturas de $5^{\circ} \mathrm{C}$ e $55^{\circ} \mathrm{C}$, em banhos de 15 segundos cada, a outra metade permaneceu acondicionada em recipientes plásticos com água deionizada a $37^{\circ} \mathrm{C}$. Após o período de teste, todos os espécimes foram imersos em solução de fucsina básica a $0,5 \%$ por 24 horas a $37^{\circ} \mathrm{C}$, sendo em seguida lavados abundantemente em água corrente durante 24 horas. Para 
análise da microinfiltração os dentes foram incluídos em resina plástica autopolimerizável e seccionados no sentido mesio-distal, sofrendo uma média de quatro cortes cada dente. Para cada corte, foram obtidas duas imagens para serem analisadas através de um software denominado Imagetools. Os resultados foram avaliados através do teste estatístico de Análise de Variância a dois critérios (2-way ANOVA) e o teste de Tukey para comparações múltiplas entre os materiais, em nível de significância de 5\%. Os resultados demonstraram que todos os grupos testados apresentaram microinfiltração marginal, sendo que o cimento de ionômero de vidro modificado por resina Vitremer apresentou resultados sempre melhores, vindo a seguir a resina composta "condensável" P-60 e por último a resina composta "semicondensável" Ariston pHc. Não houve diferença estatisticamente significante no uso ou não da termociclagem para estes materiais. Quando avaliou-se os métodos de análise de penetração do corante, o método através da máxima infiltração parece ser o melhor para detectar a extensão da microinfiltração. 


\section{1 - Introdução}




\section{1 - INTRODUÇÃO}

A história, desde o início dos tempos, tem mostrado a cárie dentária como um sério problema para o cirurgião dentista. Sabendose disto, uma das maiores preocupações na odontologia moderna é prevenir e preservar a estrutura dentária, mantendo a estética; entretanto, mesmo com os progressos das técnicas preventivas/restauradoras, a necessidade de se realizar restaurações ainda existe.

A odontologia restauradora estética tem alcançado um apelo muito grande nos últimos anos, o que determinou o aparecimento de inúmeros materiais restauradores com propriedades aprimoradas para dentes posteriores. Entretanto, para o sucesso de uma restauração, além da estética, o material deve apresentar propriedades físicomecânicas e biológicas satisfatórias; e também ser capaz de aderir diretamente à estrutura dentária, resistindo às mudanças de temperatura sem alterações volumétricas, para assim proporcionar um perfeito selamento marginal, resistente às diferenças no coeficiente de expansão térmica e módulo de elasticidade entre o dente e os materiais ${ }^{5,10}$. 
A técnica do condicionamento ácido do esmalte descoberta por BUONOCORE ${ }^{11}$ em 1955 serviu de ponto de partida para outros estudos, sendo introduzidos em 1980, por FUSAYAMA ${ }^{30}$, os sistemas adesivos de união das resinas compostas à dentina. Ainda hoje, apesar do uso dos sistemas adesivos, as principais preocupações com o desempenho de materiais restauradores dentários referem-se à durabilidade e integridade do selamento marginal ${ }^{38}$, pois não existe um vedamento total entre o material restaurador e a dentina, principalmente em cavidades estendidas à região de cemento onde os problemas clínicos se agravam ${ }^{44,50}$.

O vedamento marginal parcial possibilita a ocorrência da microinfiltração, que consiste na passagem não detectada clinicamente de bactérias, fluidos, moléculas ou íons entre a parede da cavidade e o material restaurador aplicado ${ }^{16,45,72}$, sendo considerada a principal causa de falha das restaurações.

Muitos trabalhos têm avaliado a microinfiltração dos diferentes materiais ${ }^{8,13,16,17,24,31,40,41,44,51,52,57,64,69,74}$, buscando, se não eliminá-la completamente, ao menos reduzi-la. Muitas modificações foram propostas aos materiais e técnicas restauradoras na tentativa de solucionar este problema e, assim, aumentar a longevidade das restaurações.

Nos trabalhos que avaliam a microinfiltração dos materiais dentários encontrados na literatura, a utilização do método de 
termociclagem associada ao uso de corantes foi um fator constante $13,16,17,19,22,25,26,38,43,57,61,64,74,77$. As temperaturas usadas para os testes in vitro variavam entre $0^{\circ} \mathrm{C}$ e $68^{\circ} \mathrm{C} 14,16,25,31,40,57,62,64$, baseadas em trabalhos realizados in vivo com sensores térmicos que mediam a temperatura sobre a superficie dos dentes durante a ingestão de líquidos - quentes e frios - e calculavam uma média clinicamente próxima à realidade para o procedimento laboratorial55. Porém, ROSSOMANDO; WENDT JUNIOR (1995)63 alertaram para o fato de que a necessidade da termociclagem dependia da extensão em que o material restaurador fosse termalmente condutivo em relação a sua massa e, que devido ao potencial de absorção de água pelas resinas compostas, os dentes restaurados necessitavam de pelo menos 24 horas de armazenamento em água para, primeiramente, ocorrer esta absorção.

Entre os materiais odontológicos mais utilizados na Odontopediatria estão os cimentos de ionômero de vidro, introduzido à profissão no início da década de 70 por WILSON; KENT78. O cimento de ionômero de vidro, devido a suas propriedades de adesão à estrutura dentária, liberação de flúor, biocompatibilidade e por possuir um coeficiente de expansão térmica linear semelhante ao da estrutura dentária 37,42,67 é colocado como um dos melhores materiais para prevenir a microinfiltração ${ }^{9,18,20}$ Haja vista que as diferenças de coeficientes de expansão térmica linear entre os materiais 
restauradores e as estruturas dentárias são, em grande parte, coadjuvantes no problema da microinfiltração56.

Uma nova geração de cimentos de ionômero de vidro restauradores, os cimentos de ionômero de vidro modificados por resina, foi desenvolvida e introduzida na odontologia na década de $80^{3}$. Estes sistemas foram denominados de híbridos e apresentaram melhorias nas suas propriedades; além de maior resistência, diminuição da sinérise e embebição, possibilitaram maior controle no tempo de trabalho, devido ao seu componente resinoso fotoativado $53,68,75$.

Todavia, ainda hoje, a baixa resistência à compressão e a tração dos cimentos de ionômero de vidro modificados por resina contraindicam sua aplicação em restaurações proximais de dentes posteriores $^{53}$, estimulando-se, assim, o mercado a pesquisar materiais que superem o ionômero de vidro, sem contudo perderem suas ótimas propriedades.

Pensando nisto, os fabricantes de resinas, alterando seus materiais na matriz ou na quantidade e tipo de carga $^{14}$, procuraram produzir um material restaurador estético com possibilidade de ser acomodado na cavidade dentária, quando se exerce certa pressão de condensação, indicado para restauração de classe I ou II, aos quais denominaram de resinas compostas "condensáveis"12. Recentemente, a 3M lançou no mercado uma evolução da resina Z-100, a qual 
denominou de Filtek P-60. Esta nova resina tem o TEGDMA substituído por uma mistura de duas resinas de maior peso molecular, Bis-EMA (Bisfeno A polietileno glicol dieter dimetacrilato) e UDMA (Uretana dimetacrilato), o que resultou em um perceptivel aumento de viscosidade. Com isso, acredita-se que haja uma matriz menos rígida, uma menor contração de polimerização e um envelhecimento reduzido, além da redução da afinidade por umidade, conseguida através dessa substituição de TEGDMA28,70.

Para a American Dental Association², uma restauração de resina composta ideal deve cumprir cinco requisitos: ter alta resistência ao desgaste, boa adaptação marginal, ser resistente à degradação pela água e outros solventes, ser radiopaca e de fácil protocolo²; todavia, a resina composta "condensável" ainda exige uma técnica muito sensivel e um longo tempo clínico, o que é bastante problemático quando se atende crianças.

Com o propósito de atingir também esta parte do mercado, a Vivadent, tentando associar as propriedades estéticas das resinas compostas com a liberação de flúor e biocompatibilidade dos cimentos ionoméricos e, também, com o protocolo clínico simplificado e rápido do amálgama, lança no mercado o Ariston $\mathrm{pHc}^{7,33,35,39}$. Uma resina modificada por poliácido e reforçada, disponível somente na cor branca que, segundo o fabricante, libera íons cálcio ${ }^{48}$, flúor e hidroxila ${ }^{34}$, proporcionalmente quando o $\mathrm{pH}$ da cavidade bucal aproxima-se do 
valor crítico, podendo inibir ou reduzir a incidência de cáries secundárias $29,46,65$, reduzir a formação de placa bacteriana e remineralizar a estrutura dentária através do cálcio e do flúor, além de neutralizar a ação dos ácidos com os íons hidroxilas $4,34,36,47,58,76,79$.

Baseando-se nestas informações e sendo o controle de microinfiltração, ainda, um desafio à prática clínica, torna-se válido analisar, in vitro, a microinfiltração marginal em restaurações com uma resina composta "condensável" (P-60), uma resina composta "semicondensável" com liberação de flúor (Ariston pHc) em comparação a um cimento de ionômero de vidro modificado por resina (Vitremer), além de testar a validade do método de termociclagem para esses materiais. 
2-Revisão de Literatura 


\section{2 - REVISÃO DE LITERATURA}

DARBYSHIRE; MESSER; DOUGLAS 21 , em 1988, estudaram o efeito da termociclagem e ciclagem de carga sobre a microinfiltração in vitro, de restaurações classe II confeccionadas com resina composta. Para isso, os autores utilizaram 80 pré-molares humanos hígidos extraídos, que foram preparados com broca 56 realizando-se cavidades classe II MOD com as paredes gengivais estendidas $1 \mathrm{~mm}$ abaixo da junção cemento-esmalte e instrumentos manuais para a confecção de ângulos cavo-superficiais de $90^{\circ}$. Os dentes foram divididos em 8 grupos de 10 dentes cada: Grupos 1 e 2 foram restaurados com resina composta P-30, sem nenhum material sob a mesma; Grupos 3 e 4, antecedendo a restauração com resina composta, receberam uma camada do adesivo dentinário Scotchbond; Grupos 5 e 6 receberam, previamente, uma base de cimento de ionômero de vidro Ketac-Bond para depois serem restaurados com resina composta; e os Grupos 7 e $\underline{8}$, depois de confeccionada uma base de cimento de ionômero de vidro e aplicada uma camada de adesivo dentinário, foram restaurados com resina 
composta. Os espécimes dos grupos $1,3,5$ e 7 foram submetidos à ciclagem de carga de 4,5N a $111,3 \mathrm{~N}$ durante 4.000 ciclos. Em seguida, todos os 80 espécimes sofreram termociclagem de 500 ciclos em temperaturas de $5^{\circ} \mathrm{C}$ e $55^{\circ} \mathrm{C}$, com duração de 30 s cada banho. Os dentes foram selados com esmalte de unha, respeitando-se $1 \mathrm{~mm}$ ao redor da restauração, para serem imersos em solução aquosa de nitrato de prata a $50 \%$ por 4 horas, imersos em solução foto-reveladora e expostos à luz fluorescente por 8 horas. Foram incluídos em resina acrílica, seccionados e cada corte foi avaliado em um microscópio com aumento de 8 vezes, sendo a leitura da microinfiltração feita através da medida linear em milímetros.

Os autores concluíram que as restaurações exibiram alguma extensão de microinfiltração, não sendo observada influência significante da ciclagem de carga; e demonstraram significante redução, mas não eliminação, de infiltração marginal quando o cimento de ionômero de vidro ou o adesivo dentinário foi usado anteriormente à restauração de resina composta, o que serviu de suporte para as recomendações de MCLEAN et al. (1985) que preconizavam o uso de cimento de ionômero de vidro como base de restaurações de resina composta.

Um estudo foi desenvolvido por HEMBREE JÜNIOR ${ }^{40}$, em 
1989, com o objetivo de comparar o grau de microinfiltração na margem cervical, em 48 molares humanos extraídos com cavidades classe II preparadas e, posteriormente, restauradas com resina composta (Herculite) e agente de união (Bondilite) ou resina composta (Herculite) e cimento de ionômero de vidro convencional (Ketacbond). Os espécimes foram submetidos à termociclagem em temperaturas de $4^{\circ} \mathrm{C}$ e $58^{\circ} \mathrm{C}$, com tempo de imersão de 1 minuto, durante 100 ciclos. O autor concluiu que as restaurações de resina composta com base de cimento de ionômero de vidro demonstraram significante redução da microinfiltração, em relação àquelas que não receberam este material.

PATRI56, nesse mesmo ano, realizou um estudo, in vitro, para avaliar a microinfiltração ao redor de cavidades classe II (MOD) restauradas com diferentes resinas compostas (Clearfil Photo Posterior, Heliomolar Radiopaque, Occlusin, P-30 e P-50) pela técnica convencional (adesivos: Gluma Bonde, Clearfil New Bond, Scotchbond 2 e Scotchbond DC) e mista (cimento de ionômero de vidro: 3M GlassIonomer cement, GC Lining cement e Vitrabond).Realizou oitenta preparos cavitários em terceiros molares hígidos extraídos, com parede cervical aproximadamente na junção cemento/esmalte e restaurados com dez combinações diferentes. O autor observou, através da penetração de corante, que as secções em nível da junção cemento/esmalte mostraram maior grau de microinfiltração e concluiu 
que houve diferença estatisticamente significante entre as várias combinações de materiais, onde a técnica mista apresentou menor grau de microinfiltração.

HOLTAN et al.43, em 1990, realizaram um trabalho com o objetivo de comparar a microinfiltração de restaurações de resina composta em cavidades classe V, associadas a uma base de ionômero de vidro modificado por resina, somente na parede de fundo ou estendendo-se para a margem gengival. Trinta e um pares de cavidades classe $\mathrm{V}$ circulares, envolvendo $50 \%$ de esmalte biselado e $50 \%$ de cemento, foram preparadas em terceiros molares humanos hígidos e extraídos. Após a aplicação do cimento de ionômero de vidro, condicionamento ácido do esmalte e aplicação do agente de união, a resina de microparticulas (Silux Plus) foi condensada em um único incremento e fotopolimerizada por 60 segundos. Os dentes sofreram termociclagem de 500 ciclos, constituídos por banhos de 1 minuto nas temperaturas de $5^{\circ} \mathrm{C}$ e $55^{\circ} \mathrm{C}$, para então serem submetidos à técnica de coloração com nitrato de prata e seccionados longitudinalmente, através do centro das restaurações, para análise da microinfiltração através de medida linear. Os autores concluíram que a extensão do cimento de ionômero de vidro na parede gengival não foi fator relevante para a redução da microinfiltração nessa região e sugerem que, para 
minimizar os problemas de resistência mecânica e estética, o mesmo seja recoberto totalmente pela resina composta.

No mesmo ano, MATHIS et al. ${ }^{51}$ avaliaram in vitro o uso de um cimento de ionômero de vidro (Ketac Bond), como base forradora de restaurações de resina composta (Silux), em cavidade classe V, para verificar a capacidade de selamento marginal desse material. As cavidades foram preparadas nas faces vestibular e lingual de molares humanos hígidos extraídos, onde a margem oclusal foi deixada em esmalte e a margem cervical em cemento. Após 48 horas de terminadas as restaurações, ambos os grupos sofreram termociclagem nas temperaturas de $5^{\circ} \mathrm{C}$ e $55^{\circ} \mathrm{C}$ com tempo de imersão de 1 minuto, num total de 1700 ciclos, sendo, então, imersos em solução de azul de metileno a $0,5 \%$, por 17 horas a $5^{\circ} \mathrm{C}$. Após o seccionamento longitudinal, a penetração do corante foi avaliada pela atribuição de escores com auxílio de microscópio óptico. Os resultados mostraram que a utilização da base de cimento ionômero de vidro reduziu significativamente a infiltração na parede cervical.

SCHWARTZ; ANDERSON; PELLEU JUNIOR.66, em 1990, realizaram um estudo in vitro para avaliarem o efeito da polimerização por incrementos sobre a microinfiltração de restaurações de resina composta em cavidades classe $\mathrm{V}$, como também avaliaram a utilização 
de uma base de cimento de ionômero de vidro (Ketac Bond) sob a resina. Após 24 horas de realizadas as restaurações, os dentes receberam acabamento e polimento com discos Sof-Lex e foram armazenados em solução fisiológica durante 14 dias, para então serem termociclados em temperaturas de $5^{\circ} \mathrm{C}$ e $55^{\circ} \mathrm{C}$, com tempo de imersão de 30 segundos, por 400 ciclos e serem corados pela técnica do nitrato de prata. A microinfiltração foi analisada por dois examinadores através de escores. Os autores concluíram que a utilização da base de cimento de ionômero de vidro reduziu a microinfiltração, comparada com a restauração pela técnica incremental da resina composta.

RETIEF59, em 1991, realizou uma revisão da literatura sobre testes para avaliação da microinfiltração marginal, com intuito de sugerir procedimentos padronizados para o desenvolvimento in vitro desses estudos, facilitando assim a comparação entre eles. Para o autor, os testes laboratoriais de adesão do material restaurador à estrutura dentária são sempre necessários antes de serem realizados os testes clínicos com o material, pois avaliam a força adesiva à dentina, a microinfiltração e as dimensões das fendas marginais na interface dente/restauração. $\mathrm{O}$ autor concluiu que os preparos cavitários utilizados, nesses testes, eram em sua maioria de classe V e que a técnica de termociclagem mais utilizada para avaliar os coeficientes de expansão e contração entre o dente e o material 
consistia em 500 ciclos, com temperaturas de $\pm 8^{\circ} \mathrm{C}$ e $\pm 50^{\circ} \mathrm{C}$, para banhos com duração de 15 segundos (tempo máximo de sustentação da temperatura na cavidade bucal). Sugeriu, ainda, que com exceção do corante nitrato de prata, os espécimes deveriam ser termociclados em solução corante, e não serem imersos no corante após a termociclagem; por fim, referiu-se à análise da microinfiltração pela penetração do corante nas interfaces dente/restauração, como um procedimento usual e de sucesso.

SILVA E SOUZA JÚNIOR et al.69, em 1991, desenvolveram uma pesquisa a fim de determinar a capacidade de vedamento marginal de cinco sistemas adesivos restauradores disponíveis no mercado. Foram realizadas cavidades $\mathrm{MOD}$, com a parede gengival localizada $2 \mathrm{~mm}$ acima ou abaixo da junção cemento/esmalte, em 40 pré-molares recém extraídos por razões ortodônticas. Os sistemas restauradores testados foram: (1) ARM + Adaptic; (2) Gluma + Lumifor; (3) Bondilite + Herculite; (4) Scotchbond + P-30 e (5) Glass Ionomer Liner + Scotchbond + P-30. Para cada sistema foram realizadas oito restaurações. Os espécimes foram submetidos durante uma semana a 105 ciclos de temperaturas a $5^{\circ} \mathrm{C}$ e $55^{\circ} \mathrm{C}$, sendo que o último ciclo foi realizado com os dentes mergulhados em saliva artificial previamente corada como Rhodamina-B a 0,1\%. Após a secção dos espécimes, o grau de infiltração foi analisado através de escores, onde os autores 
puderam concluir que nenhuma combinação estudada foi capaz de impedir totalmente a infiltração do corante. Observaram, também, que para as margens em esmalte houve um melhor desempenho quando se empregou os sistemas (5), (4) e (3), respectivamente, e para as margens em cemento a eficácia mais acentuado foi para o sistema (5).

RETIEF; McCAGHREN; RUSSEL60, em 1992, realizaram um estudo in vitro para avaliar a microinfiltração de restaurações classe II MOD com a resina composta P-50 associada a uma base de cimento de ionômero de vidro modificado por resina Vitrabond. Os autores utilizaram 30 molares permanentes humanos, extraídos, hígidos, onde a parede gengival, na face mesial, foi estendida $1 \mathrm{~mm}$ abaixo da junção cemento-esmalte e na face distal, $1 \mathrm{~mm}$ acima da junção cementoesmalte. Depois de realizados os preparos, os 30 molares foram divididos em dois grupos de 15 dentes cada: no grupo (A), o Vitrabond foi aplicado sobre toda a superficie dentinária, mas sem estendê-lo até a margem cavo-superficial da parede gengival; no grupo $\mathrm{B}$, incluiu-se toda a extensão da parede gengival. Após a polimerização do Vitrabond, as margens de esmalte foram condicionadas com ácido fosfórico a $37 \%$ por 30 segundos e aplicou-se Scotchbond 2 por toda a superficie durante 60 segundos, incluindo a superficie do cimento de ionômero de vidro Vitrabond, e polimerizou-se por 30 segundos. Todos os dentes foram restaurados com a resina composta P-50 que foi 
condensada na cavidade pela técnica incremental e armazenados por uma semana em solução fisiológica a $37^{\circ} \mathrm{C}$. Os ápices foram preparados com uma broca carbide cone invertido, receberam duas camadas de verniz copalite e foram obliterados com amálgama. Duas camadas de esmalte para unha foram aplicadas em todo o dente com exceção da restauração e $1 \mathrm{~mm}$ ao seu redor. Os espécimes foram, então, termociclados em solução de fucsina básica $0,5 \%$ por 250 vezes nas temperaturas de $8^{\circ} \mathrm{C}$ e $50^{\circ} \mathrm{C}$, durante $15 \mathrm{~s}$ cada banho, sendo incluídos em resina epóxica transparente e seccionados no sentido mesio-distal para a avaliação da penetração do corante através de escores, com auxilio de um microscópio de dissecação com aumento de 50 vezes. Os autores observaram que a infiltração marginal foi significantemente menor quando se estendeu a base de Vitrabond até o ângulo cavo superficial e significantemente maior quando as margens gengivais localizavam-se abaixo da junção cemento-esmalte.

Ainda em 1992, RIGSBY et al.62 realizaram um estudo in vitro com o objetivo de avaliar a microinfiltração de restaurações com sistema adesivo/resina composta (XR Bonding System/Herculite XR) submetidos a estresse térmico ou mecânico ou a ambos. Nesse estudo, foram utilizados 24 molares inferiores hígidos preparados com cavidades classe $\mathrm{V}$ (com margens $1,5 \mathrm{~mm}$ acima e abaixo da junção esmalte-dentina) que foram divididos em 3 grupos de 8 dentes cada. 
No grupo 1 , o procedimento realizado foi apenas termociclagem de 500 ciclos, com banhos de 15 segundos em fucsina, nas temperaturas de $8^{\circ} \mathrm{C}$ e $50^{\circ} \mathrm{C}$. No grupo 2 , os dentes sofreram estresse mecânico oclusal em solução de fucsina básica $0,5 \%$ a $37^{\circ} \mathrm{C}$, equivalente a $34 \mathrm{Mpa}$ e no grupo 3, os espécimes receberam os dois procedimentos acima descritos.

Após a avaliação estatística pelo teste de Kruskal-Wallis e Student-Newman-Keuls, com níveis de significância de 5\%, os resultados mostraram que nas margens em esmalte não foi observada microinfiltração após estresse térmico, mecânico ou ambos. Nas margens em dentina/cemento não houve diferença significante na microinfiltração, quando comparado efeito do estresse térmico ou mecânico, isoladamente; porém, quando os espécimes foram submetidos aos estresses térmico e mecânico conjuntamente, a diferença foi altamente significante.

Com a intenção de realizar uma revisão da literatura sobre os vários métodos de avaliação da microinfiltração marginal em torno das restaurações dentárias, TAYLOR; LYNCH $72^{72}$ também em 1992, relataram a existência de uma grande variedade de tipos de avaliação. Entre elas, citaram a utilização de ar comprimido, os testes bacterianos, a condutividade elétrica, a ativação de nêutrons, a formação de cáries artificiais, o uso de agentes traçadores químicos e 
radioativos, o uso de corantes orgânicos, a associação do uso de corantes com ciclagem de carga (mecânica) e/ou a termociclagem. Os autores concluíram que havia vantagens e desvantagens para cada técnica, existindo assim a necessidade de um método padrão para os trabalhos que possibilitasse a comparação entre eles. Citaram a utilização de testes bacterianos como o melhor método para trabalhos in vivo, mas ressaltaram a necessidade de grande número de espécimes, tempo e dinheiro para um experimento desse tipo. Para os trabalhos in vitro, os autores classificaram o uso de corantes como o método mais utilizado por ser prático e rápido, demonstrando a infiltração em cores contrastantes com as estruturas dentárias e os materiais restauradores, porém com necessidade de padronização criteriosa, uma vez que é feito de maneira subjetiva.

Para estudar o efeito da termociclagem sobre a penetração do corante durante a avaliação da microinfiltração in vitro, em restaurações confeccionadas com resina composta, WENDT; McINNES; DICKINSON77, em 1992, utilizaram 50 molares humanos hígidos extraídos, nos quais foram realizados preparos classe II MOD com broca 245, de maneira que uma de suas faces proximais tivesse a parede gengival terminando em esmalte $(1 \mathrm{~mm}$ abaixo da parede pulpar) e a outra tivesse a parede gengival terminando abaixo da junção cemento-esmalte ( $2 \mathrm{~mm}$ abaixo). Os dentes foram restaurados 
com o sistema Scotchbond 2 / P-50 e foram divididos em cinco grupos: Grupo A não termociclado e imerso em solução de fucsina básica a $0,5 \%$ por $24 \mathrm{~h}$ a $37^{\circ} \pm 1^{\circ} \mathrm{C}$; Grupo $\mathrm{A}^{\prime}$ não termociclado e imerso em solução de fucsina básica a $0,5 \%$ por $4 \mathrm{~h}$ a $37^{\circ} \pm 1^{\circ} \mathrm{C}$; Grupo-B termociclado em água durante 250 ciclos, nas temperaturas de $5^{\circ} \mathrm{C}$ e $50^{\circ} \mathrm{C}$ com permanência de $15 \mathrm{~s}$ em cada banho e em seguida imerso em solução de fucsina básica a 0,5\% por 24h; Grupo B' termociclado como o grupo B e imerso no corante fucsina básica a $0,5 \%$ por 4 h; Grupo C onde a termociclagem foi realizada no corante (fucsina básica a 0,5\%). Todos os dentes foram incluídos em resina acrílica, seccionados em 3 secções cada, sendo cada corte avaliado em um estereomicroscópio e a leitura da microinfiltração feita através do método de atribuição de escores.

Após a avaliação estatística pelo método não-paramétrico de Kruskall-Wallis e o método paramétrico de ANOVA, todos os grupos exibiram alguma extensão de microinfiltração. Entretanto, houve diferença estatisticamente significante entre o grupo B e os demais grupos, quando se considerou a microinfiltração em esmalte. Quando os grupos foram comparados em relação à margem em cemento não foram observadas diferenças estatisticamente significantes. Os resultados desse trabalho mostraram que não houve diferença estatisticamente significante entre a termociclagem realizada no corante e a termociclagem feita na água, com posterior imersão no 
corante. Entretanto, deve-se levar em consideração o tempo de permanência nos banhos para evitar-se a sorpção de água e a possível hidrolização do adesivo.

DAVIS et al. ${ }^{22}$, em 1993, estudaram a infiltração marginal de cavidades classe $\mathrm{V}$ restauradas pela técnica laminada com três cimentos de ionômero de vidro modificados por resina (Geristore/DenMat, Vitrebond/3M, Zionomer/Den-Mat) ou um cimento de ionômero de vidro convencional (Ketac-Bond/ESPE) utilizados como base para a resina composta P-50. Foram utilizados 20 molares humanos, onde as cavidades foram confeccionadas nas paredes vestibular e lingual. Todos os cimentos de ionômero de vidro modificados por resina, incluídos neste estudo, foram aplicados às cavidades em finas camadas e fotopolimerizados por 40 segundos; já o cimento de ionômero de vidro convencional foi deixado por 4 minutos para endurecer, antes da aplicação da resina composta para o término da restauração. Os espécimes após sofrerem acabamento e polimento, permaneceram armazenados por 72 horas a $37^{\circ} \mathrm{C}$ em $100 \%$ de umidade, para então sofrerem termociclagem de 1500 ciclos de 15 segundos cada, nas temperaturas de $4^{\circ} \mathrm{C}, 37^{\circ} \mathrm{C}, 54^{\circ} \mathrm{C}$ e $37^{\circ} \mathrm{C}$. Em seguida, foram mergulhados em fucsina a $2 \%$ por 24 horas e após esse período, seccionados para avaliação da microinfiltração pelo sistema de escores. Os resultados, deste estudo, demonstraram não haver 
diferença estatisticamente significante entre os grupos, pois todos os materiais apresentaram algum grau de microinfiltração (leve ou moderado) na margem de cemento ou dentina.

CRIM; CHAPMAN19 (1994) estudaram in vitro quatro protocolos para reduzir a microinfiltração marginal de restaurações de resina composta em cavidades classe II. Foram utilizados 20 molares humanos hígidos, extraídos por razões ortodônticas, divididos em 4 grupos de 5 dentes, com duas cavidades cada. No grupo 1, as restaurações foram realizadas com Fuji II LC, Prisma Universal Bond 3 Primer, Prisma Adhesive, APH; para o grupo 2 foram utilizadas BondAband (matriz), Prisma Universal Bond 3 Primer, Prisma Adhesive, APH; no grupo 3 foram utilizadas Prisma Universal Bond 3 Primer, Prisma Adhesive, APH.; no grupo 4, Coltene Duo-Bond, APH. Após serem armazenados por 24 horas em água a $37^{\circ} \mathrm{C}$, os espécimes sofreram termociclagem por 100 ciclos nas temperaturas de $37^{\circ} \mathrm{C}$ por $23 \mathrm{~s}, 12^{\circ} \mathrm{C}$ por $4 \mathrm{~s}, 37^{\circ} \mathrm{C}$ por $23 \mathrm{~s}$ e $54^{\circ} \mathrm{C}$ por $4 \mathrm{~s}$ para serem imersos em solução aquosa de fucsina básica por 24 horas. Cada dente foi seccionado no sentido mesio-distal através do centro da restauração e a microinfiltração da margem cervical avaliada com auxilio de microscópio óptico com aumento de 50 vezes. Os autores concluíram que o grupo 4 (adesivo de esmalte) obteve a maior microinfiltração e que o grupo 1 (cimento de ionômero de vidro modificado por resina) 
apresentou, significantemente, menor microinfiltração que os grupos 2 (BondAband) e 3 (adesivo dentinário).

FUTATSUKI; NAKATA ${ }^{31}$ em 1994, realizaram um estudo in vitro para avaliar a infiltração marginal de restaurações de resina composta em cavidades classe II. Os autores utilizaram 40 pré-molares humanos que foram divididos em 4 grupos: (1) Occlusin com Bonding Agent, (2) Palfique Light-S com Light Bond, (3) P-50 com Dentin Primer e Scotchbond 2 e (4) P-50 com Vitrabond e Scotchbond 2. Os dentes, para a restauração, tinham suas raízes incluídas em resina autopolimerizável, juntamente com outro pré-molar extraído, sendo, também, utilizadas matrizes e cunhas reflexivas para simular a condição clínica. Após o acabamento e polimento realizado 12 horas depois da restauração, os dentes foram termociclados durante 100 ciclos nas temperaturas de $4^{\circ} \mathrm{C}$ e $60^{\circ} \mathrm{C}$ e mergulhados em solução de fucsina básica a $0,5 \%$ por 24 horas a $37^{\circ} \mathrm{C}$. A avaliação foi realizada através de escores, com auxilio de microscópio óptico com aumento de 40 vezes. Os resultados demonstraram que o selamento marginal na parede cervical teve menor infiltração quando se usou o adesivo dentinário, em comparação ao adesivo de esmalte convencional (Bonding Agente) e o cimento de ionômero de vidro modificado por resina impediu a penetração do corante na dentina quando utilizado 
como base forradora, embora haja ocorrido infiltração em nivel de esmalte em todos os espécimes deste grupo.

RETIEF; MANDRAS; RUSSEL61 em 1994, estudando a microinfiltração nas cavidades classe II, com margens cervicais em cemento, restauradas com resina composta e submetidas a estresse mecânico e térmico, observaram um maior grau de infiltração marginal nas restaurações submetidas aos estresses térmico e mecânico conjuntamente e concluíram que a utilização do sistema adesivo não reduziu a infiltração marginal tanto quanto o cimento de ionômero de vidro reduzira.

CARRARA ${ }^{16}$ em 1995, realizou um estudo in vitro com o propósito de comparar a infiltração marginal de dois cimentos ionoméricos restauradores que liberam flúor. O autor confeccionou, em 13 prémolares humanos extraídos hígidos, cavidades classe II padronizadas em $4 \mathrm{~mm}$ de largura, $1 \mathrm{~mm}$ de profundidade na região da parede gengival e $1 \mathrm{~mm}$ abaixo da junção cemento-esmalte. Após os preparos, cada dente recebeu uma restauração de cimento de ionômero de vidro modificado por resina Vitremer e outra de cimento de ionômero de vidro modificado por poliácido Variglass, de acordo com as instruções do fabricante. Após as restaurações, os dentes tiveram seus ápices obliterados e realizou-se o pincelamento dos mesmos com duas 
camadas de esmalte para unha, respeitando-se $1 \mathrm{~mm}$ ao redor das restaurações, para posteriormente serem submetidas a termociclagem em fucsina básica a 0,5\%, com 500 ciclos nas temperaturas de $5^{\circ} \mathrm{C}$ e $55^{\circ} \mathrm{C}$, com banhos de 15 segundos. A microinfiltração foi avaliada, através de escores em microscópio óptico, utilizando-se a técnica de secção longitudinal única, obtendo-se duas fatias para avaliação, sendo considerada para a analise estatística apenas a de maior escore. O teste estatístico utilizado foi o de Wilcoxon. O autor concluiu que nenhum material foi capaz de impedir totalmente a infiltração marginal, sendo que o Vitremer apresentou menor microinfiltração do que o Variglass.

GWINNETT et al. ${ }^{38}$ em 1995, compararam a microinfiltração ao longo da interface dentina-restauração através do uso de dois protocolos estereoscópicos modificados e um protocolo convencional de uma única superficie. Os autores padronizaram em 30 terceiros molares humanos hígidos, recém extraídos e armazenados em cloramina $\mathrm{T}$ a $1 \%$, a $5^{\circ} \mathrm{C}$ até serem usados, cavidades cilindricas classe $\mathrm{V}$ (3mm de diâmetro e $2 \mathrm{~mm}$ de profundidade) realizadas junto à junção esmalte/cemento nas superficies bucais, mantendo-se metade da restauração acima da junção e metade, abaixo. Após a restauração dos espécimes com Scotchbond 2/P-50, estes foram armazenados em água destilada a $37^{\circ} \mathrm{C}$ por 24 horas e submetidos a 500 ciclos de 
termociclagem com banhos de 30 segundos em temperaturas de $5^{\circ} \mathrm{C}$ e $55^{\circ} \mathrm{C}$ com seus ápices abertos. Realizada a termociclagem, o ápice foi obturado com Vitremer e aplicada em suas raízes uma camada de esmalte para unha, respeitando-se $1 \mathrm{~mm}$ das margens da restauração. Em seguida, foram imersas em solução aquosa de nitrato de prata a 50wt\% por 2 horas em total escuridão e enxaguados em água corrente por 30 minutos, imersos em solução foto-reveladora e expostos à luz fluorescente por 6 horas para a redução completa dos íons prata. Depois de removida a solução reveladora, os dentes foram enxaguados em água corrente, antes de serem imersos em acetona por 10 minutos para dissolver a camada de esmalte para unhas. Os 30 dentes foram distribuídos ao acaso em 3 grupos de 10 espécimes. O grupo I representou os dentes com secção longitudinal através da linha média da restauração, sendo examinadas sob um esterioscópio óptico e registrada a metade do dente que exibia infiltração mais severa; o grupo II representou o protocolo de "clearing", quando os dentes foram desmineralizados e radiografados para o exame no esterioscópio óptico para registrar a microinfiltração total da restauração e o grupo III representou o protocolo de múltiplas superficies (de 39 a 55) realizadas por desgaste, sendo as imagens registradas por uma câmera de vídeo colorida adaptada a um microcomputador. A severidade da microinfiltração para todos os grupos foi registrada em uma escala ordinal e baseada no comprimento linear da infiltração. 
Quando as comparações foram realizadas com a análise estatística não paramétrica, tanto o protocolo para múltiplas superficies quanto para a depuração registraram infiltração significantemente mais severa do que a detectada a partir da técnica convencional. Porém, entre os dois protocolos estereoscópicos, não houve nenhuma diferença significante. Os autores concluíram que: 1o protocolo de uma secção longitudinal única convencional ao longo da linha média da restauração parece subestimar a extensão total da microinfiltração; 2- ambos os protocolos estereoscópicos descritos foram igualmente eficazes quanto ao traçado de um padrão de microinfiltração ao longo da interface dentina/restauração; 3- a microinfiltração foi mais severa ao longo das regiões extremas do que ao longo do centro da margem cervical quando os dentes foram restaurados com Scotchbond 2 e P-50.

No mesmo ano, ROSSOMANDO; WENDT JUNIOR ${ }^{63}$ realizaram um estudo sobre o efeito da duração dos banhos (10s e 60s) em cada temperatura durante a ciclagem térmica, através da análise da microinfiltração de três técnicas para restaurações adesivas: resina composta, adesivo/resina composta e adesivo/amálgama. Para esse estudo os autores utilizaram terceiros molares hígidos e realizaram, com brocas carbide $\mathrm{n}^{\circ} 245$ montadas em caneta de alta rotação, refrigeradas a água e ar, 90 preparos tipo classe $\mathrm{V}$ com margem 
cervical localizada $2 \mathrm{~mm}$ abaixo da junção esmalte/cemento e $2 \mathrm{~mm}$ no esmalte. Os espécimes tiveram seus ápices obturados com amálgama e foi utilizada uma camada de esmalte respeitando-se $1 \mathrm{~mm}$ das margens da restauração para então serem divididos em 3 grupos de 30 preparos em cada grupo: o $1 .^{\circ}$ grupo (grupo controle) que não sofreu termociclagem; o $2 .^{\circ}$, grupo experimental com termociclagem com banho de 10 segundos em fucsina básica e o $3 .^{\circ}$ grupo, com termociclagem com banhos de 60 segundos em fucsina básica. O tempo de permanência em contato com a fucsina para o grupo controle foi equivalente ao tempo de exposição à fucsina dos grupos que foram termociclados. Após a remoção da solução, os dentes foram seccionados em 2 secções de $1 \mathrm{~mm}$. A avaliação foi feita através de um estereomicroscópio, onde ambos os lados de cada secção foram avaliados através de escores, produzindo-se 4 leituras para cada restauração e os dados foram submetidos a uma análise estatística não-paramétrica pelo método de Kruskal-Wallis.

De acordo com os resultados do trabalho, os autores concluíram que em todos os grupos e materiais observou-se a presença de microinfiltração na margem cemento/dentina. $O$ grau de microinfiltração observado para todos os materiais foi maior nos espécimes expostos ao maior tempo de estresse térmico (60s). Para as restaurações com resina composta não houve diferença estatisticamente significante entre o grupo não termociclado e o 
termociclado. Quando os espécimes foram submetidos a ciclos com banhos de 10s, duração mais compatível clinicamente, não foi observado aumento no nível de infiltração.

DÉJOU; SINDRES; CAMPS ${ }^{23}$ em 1996, realizaram um estudo in vitro com o objetivo de comparar e explicar os métodos estatísticos empregados para avaliar a eficiência do selamento de sistemas restauradores adesivos, através da microinfiltração. Para tanto, utilizaram 260 pré-molares ou molares humanos hígidos, extraídos por razões protéticas ou periodontais e divididos ao acaso em 13 grupos de 20 dentes cada. Foram preparadas cavidades classe V padronizadas, sendo os dentes restaurados com 13 sistemas restauradores, submetidos à termociclagem por 100 ciclos $\left(5^{\circ} \mathrm{C}\right.$ e $\left.55^{\circ} \mathrm{C}\right)$ com o tempo de permanência de 30 segundos, imersos em solução de fucsina básica a $0,5 \%$ por 24 horas a $37^{\circ} \mathrm{C}$, enxaguados em água de torneira, secos e incluídos em resina Epóxi para serem seccionados em um plano vestibulo-lingual, realizando-se três secções. Desse modo, criaram-se seis interfaces que foram examinadas sob microscópio em um aumento de 100 vezes. Os autores registraram cinco critérios de avaliação: a média dos seis dados de penetração do corante, medidas em cada dente, a mediana desses seis dados, a moda dos dados, a penetração máxima do corante para cada dente e as porcentagens dos dentes em cada grupo, sem qualquer penetração do corante medida 
nas seis interfaces. Para cada parâmetro, foi utilizado o teste estatístico de ANOVA e posteriormente a análise de variância de Duncan para comparar os treze sistemas.

Os autores concluíram que o parâmetro estatístico de infiltração máxima deve ser considerado como a medida comparativa mais adequada para a condição clínica, embora varie em relação ao tipo de experimento, material restaurador utilizado e critério de avaliação. Concluíram, também, que a penetração de corante é um método de avaliação in vitro bastante usado para verificar a eficiência do selamento dos vários sistemas restauradores adesivos.

DOERR; HILTON; HERMESCH26 também em 1996, avaliaram in vitro os efeitos da termociclagem sobre a microinfiltração em cavidades restauradas com cimento de ionômero de vidro convencional (Ketac-Fil Aplicap) e modificado por resina (PhotacFil Aplicap). Para isto, os autores utilizaram 30 terceiros molares humanos hígidos, que foram preparados com broca 330, realizando-se preparos classe V nas faces vestibular e lingual, com margem gengival $1,5 \mathrm{~mm}$ abaixo e acima da junção amelo-cementária. As cavidades relativas a uma das faces foram restauradas com cimento de ionômero de vidro convencional Ketac-Fil Aplicap e as correspondentes a outra face foram restauradas com o cimento de ionômero de vidro modificado por resina Photac Fil Aplicap, sendo o acabamento e polimento das margens das 
restaurações realizado imediatamente após as mesmas. Os espécimes foram armazenados por uma semana em água destilada à temperatura ambiente, para então metade deles serem submetidos à termociclagem de 2500 ciclos, permanecendo 5 segundos a $5^{\circ} \mathrm{C}$ e $55^{\circ} \mathrm{C}$. Em seguida, os ápices foram obturados, as superficies oclusais sofreram ataque ácido (com ácido fosfórico a 37\%) e foram selados com selantes de fóssulas e fissuras, sendo aplicado em suas raízes 2 camadas de esmalte de unha, respeitando-se $1,5 \mathrm{~mm}$ das margens da restauração, sendo em seguida, imersos em solução de azul de metileno a $5 \%$ por 5 horas. Após 30 segundos de escovação embaixo de água corrente, os dentes foram incluídos em resina acrílica, seccionados longitudinalmente no sentido vestíbulo-lingual e cada corte foi avaliado em um estereomicroscópio com aumento de 64 vezes. O índice de penetração do corante foi avaliado estatisticamente pelo método de ANOVA (termociclagem $\mathrm{x}$ material). Os resultados demonstraram que nenhum material, termociclado ou não, teve diferença estatisticamente significante na penetração do corante.

MILLER, et al. ${ }^{52}$ ainda em 1996, realizaram um estudo in vitro com o propósito de determinar o melhor material restaurador a ser utilizado em incrementos gengivais na caixa proximal de restaurações classe II de resina, para minimizar a microinfiltração. Os autores prepararam cavidades classe II em 60 dentes humanos extraídos 
hígidos e estocados em solução de timol 0,2\% por em média 4,5 meses, onde a parede cervical foi estendida $1 \mathrm{~mm}$ abaixo da junção cementoesmalte. Depois de realizados os preparos, os sessenta dentes foram divididos em 6 grupos de 10 dentes cada: no grupo 1 foi utilizada a resina Heliomolar em três incrementos, por ser a única resina de micropartículas comercializada para o uso em restaurações classe II; no grupo 2, foi utilizada a resina Bisfil 2B no incremento gengival, seguida por dois incrementos de resina Heliomolar, para assim poder testar se a baixa viscosidade e a ativação química poderiam reduzir a microinfiltração; no grupo 3, o incremento gengival foi preenchido com cimento de ionômero de vidro modificado por resina Vitremer, seguido por dois incrementos da resina Heliomolar, para assim poder testar a baixa viscosidade, a dupla polimerização e a diferença química, comparadas com os outros materiais; para o grupo 4, o preenchimento da cavidade foi feito com três incrementos de resina Tetric, porque tem viscosidade semelhante à resina Heliomolar, porém é híbrida; o grupo 5 e o grupo 6 foram restaurados da mesma maneira que os. grupos 2 e 3, respectivamente, porém com a substituição da resina Heliomolar pela Tetric. Após as restaurações os espécimes foram armazenados em água destilada à temperatura ambiente por duas semanas para, então, serem submetidos a três períodos de 100 termociclos nas temperaturas de $5^{\circ} \mathrm{C}$ e $55^{\circ} \mathrm{C}$, com permanência de $8 \mathrm{~s}$ em cada banho, alternadas com duas ciclagens de carga de 25.000 ciclos com $161 \mathrm{~b}$ 
(7,26Hg.). Os dentes foram imersos em solução de nitrato de prata a $50 \%$ por 4 horas e seccionados no sentido mesio-distal, obtendo-se de cada dente 5 secções diferentes. A penetração do corante foi registrada através da atribuição de escores, de acordo com a extensão de penetração do corante nas paredes gengivais, com auxilio de um microscópio com aumento de 40 vezes. Os testes estatísticos aplicados foram o ANOVA e o Kruskal-Wallis.

Os autores concluíram que os cimentos ionoméricos modificados por resina, como o Vitremer, colocados na porção gengival de classes II podem ser um método prático de reduzir a microinfiltração. Também observaram que materiais de baixa viscosidade com ativação química podem ter infiltração menor do que materiais de alta viscosidade fotoativados e que para as condições aplicadas neste estudo, a diferença entre o uso de uma resina de micropartículas ou híbrida não mostrou ser significante para a prevenção da microinfiltração marginal.

ALANI; TOH ${ }^{1}$ (1997) realizaram uma revisão da literatura sobre as várias técnicas usadas em estudos de microinfiltração, com o intuito de preparar um guia para as futuras investigações. Os estudos in vitro, segundo os autores, incluem o uso de corantes orgânicos, os agentes traçadores e radioativos, os testes bacterianos, o uso de ar comprimido, a indução de carie artificial, a análise de ativação de 
nêutrons, a condutividade térmica, a termociclagem associada ou não à ciclagem de carga e a microscopia eletrônica de varredura. Em relação à termociclagem e sua influência sobre a microinfiltração consideraram as faixas de temperaturas utilizadas, a duração e os intervalos dos banhos, além do número de ciclos, relacionando-os ao volume, condutibilidade e capacidade de sorpção de água do material restaurador. Os autores, ainda, discutem a associação ou não da ciclagem de carga (mecânica) à termociclagem dos dentes restaurados, pois consideram que os estresses mecânicos podem promover a deformação permanente ou temporária do material, simulando as condições do meio bucal. Os autores resumem as vantagens e desvantagens de cada método para a detecção da microinfiltração e concluem que apesar de não existir um método ideal para a avaliação da microinfiltração, a utilização de corantes é considerada um método prático e confiável para estudos in vitro, pois permite uma comparação razoável entre diferentes técnicas e materiais restauradores, apesar das avaliações serem subjetivas.

HILTON; SCHWARTZ; FERRACANE41, em 1997, realizaram um estudo in vitro com o propósito de avaliar a microinfiltração em restaurações de resina composta fotopolimerizável em cavidades classe II colocadas em torno de $30^{\circ} \mathrm{C}$, simulando a temperatura intrabucal, com duas técnicas em incrementos e uma técnica de contração direta. 
Procuraram, ainda, comparar a técnica de secção única longitudinal e a técnica de avaliação tridimensional para medir a microinfiltração. Os autores realizaram cavidades classe II em vinte terceiros molares humanos recém extraídos e hígidos, sendo em seguida divididos em dois grupos de 10 dentes cada: o primeiro denominado de curto, cujas medidas estavam entre 4,6 a 5,5mm de altura da cavidade e o segundo (longo) com medidas entre 5,9 e 6,7mm de altura. Para a restauração, a única regra seguida foi que todas as técnicas empregadas deveriam ter cinco restaurações na mesial e cinco na distal, como também um mesmo numero de restaurações curtas e longas. Foram empregadas quatro técnicas: técnica $\mathrm{A}$, através de um incremento gengival e dois incrementos verticais com o auxílio da matriz transparente e cunhas reflexivas; técnica $B$, realizada através de três incrementos horizontais com auxilio de matriz metálica; técnica $\mathrm{C}$, realizada através de dois incrementos horizontais, sendo o primeiro incremento (maior) composto por resina autopolimerizável e o segundo (terço oclusal) por resina fotopolimerizavél com auxílio de matriz metálica; técnica $D$, restaurada com a mesma técnica de condicionamento ácido e adesivo utilizada na técnica A e com a colocação dos incrementos conforme a técnica C. O acabamento foi realizado imediatamente após o término das restaurações, sendo as mesmas armazenadas durante 9 a 12 dias a $37^{\circ} \mathrm{C}$, para posteriormente serem submetidas a 1000 ciclos de $5^{\circ} \mathrm{C}$ e $55^{\circ} \mathrm{C}$ em água, com banhos de 30 segundos. A microinfiltração foi 
avaliada utilizando-se, primeiramente, a técnica de secção longitudinal única e depois, após a remoção cuidadosa do material restaurador da cavidade, através da técnica tridimensional, usando escores. Os autores concluíram existir um maior grau de microinfiltração nas restaurações com a margem em dentina-cemento e consideraram, ainda, que o uso da técnica de única secção pode subestimar o grau de infiltração marginal, quando comparada à técnica tridimensional.

PIN57 (1997) realizou um trabalho in vitro, com o objetivo de avaliar a infiltração marginal de um cimento de ionômero de vidro convencional Fuji IX, de dois cimentos de ionômero de vidro modificados por resina Fuji II LC e Vitremer, e de uma resina composta modificada por poliácidos Dyract. Para tanto foram preparadas cavidades classe II proximais, com envolvimento da crista marginal e parede gengival $1 \mathrm{~mm}$ abaixo da junção cemento/esmalte, nas superficies mesiais e distais de 40 pré-molares humanos livres de cárie, extraídos por indicação ortodôntica e restauradas com os materiais citados acima. Os dentes tiveram os seus forames apicais alargados e selados com duas camadas de verniz e amálgama. O restante do dente, respeitando $1 \mathrm{~mm}$ ao redor da restauração, recebeu duas camadas de esmalte para unhas. Todos os espécimes foram submetidos à termociclagem em água destilada nas temperaturas de $5^{\circ} \mathrm{C}$ e $55^{\circ} \mathrm{C}$, com tempo de imersão de $15 \mathrm{~s}$, durante 500 ciclos. Em 
seguida, foram mergulhados em solução de fucsina básica a $0,5 \%$ a $37^{\circ} \mathrm{C}$ durante 24h. Procedeu-se, então, ao seccionamento dos espécimes e a infiltração marginal na interface dente/restauração, para cada face dos cortes, foi avaliada através da medida linear (micrometros) da penetração do corante ao longo da parede gengival, utilizando-se um microscópio óptico com aumento de 30 vezes. A autora concluiu com a análise dos resultados que nenhum dos materiais testados foi capaz de impedir totalmente a infiltração marginal. As restaurações de Vitremer mostraram, significativamente, menor infiltração marginal que todos os outros materiais. Os materiais Fuji II LC e Dyract apresentaram um padrão de infiltração marginal semelhante entre si, o que os posicionou em um nivel intermediário de infiltração com relação aos outros materiais. O cimento de ionômero de vidro convencional Fuji IX mostrou os piores resultados frente aos testes, em comparação a todos os outros materiais $(\mathrm{p}<0,05)$.

SALLES ${ }^{64}$ em 1997, realizou um trabalho com o objetivo de avaliar in vitro a influência de dois sistemas adesivos (One Step/Bisco e All Bond 2/Bisco) considerados universais, na infiltração marginal de restaurações realizadas com um cimento de ionômero de vidro modificado por resina (Vitremer/3M) e uma resina composta modificada por poliácidos (Dyract/Dentsply). Para isso, cavidades classe II, proximais com envolvimento de crista marginal, foram 
confeccionadas em 40 pré-molares hígidos extraídos por indicação ortodôntica, sendo que a avaliação foi realizada na parede gengival dessas restaurações que se encontravam a $1 \mathrm{~mm}$ da junção cementoesmalte. Os espécimes foram divididos em 4 grupos de 20 restaurações cada, sendo que o grupo 1 recebeu um tratamento com o adesivo dentinário One Step/Bisco e foi restaurado com o Dyract/Dentsply; o grupo 2 recebeu o mesmo sistema adesivo e foi restaurado com o Vitremer/3M; o grupo 3 recebeu o adesivo All Bond 2/Bisco e foi restaurado com o Dyract/Dentsply, e o grupo 4 recebeu o mesmo sistema adesivo que o grupo 3 e foi restaurado com o Vitremer/3M. Depois das restaurações realizadas, os espécimes foram selados com duas camadas de esmalte de unha, exceto a restauração e $1 \mathrm{~mm}$ ao seu redor, e os ápices radiculares foram selados com duas camadas de verniz copal e o amálgama dentário. Procedeu-se então à ciclagem térmica em água destilada nas temperaturas de $5^{\circ} \mathrm{C}$ e $55^{\circ} \mathrm{C}$ por 500 ciclos, e os espécimes foram imersos em solução de fucsina básica a 0,5\% por 24 horas. A seguir, os dentes foram lavados e seccionados em várias porções para análise da microinfiltração em microscopia óptica através de medida linear (micrometros). A autora concluiu, com os resultados desse estudo, que nenhum dos materiais testados foi capaz de eliminar completamente a microinfiltração na parede gengival das restaurações, porém esta microinfiltração foi maior para os grupos que receberam o Dyract/Dentsply, independente dos sistemas 
adesivos utilizados. 0 Vitremer/3M pareceu reduzir significativamente a microinfiltração, quando comparado com o Dyract/Dentsply. Os sistemas adesivos utilizados pareceram não influenciar de maneira significativa a redução da microinfiltração quando em combinação com os materiais restauradores utilizados.

CARDOSO; VIEIRA ${ }^{13}$ em 1998, avaliaram a capacidade de vedamento marginal proporcionado por três sistemas adesivos em cavidades classe II restauradas com resina composta. Para isso, os autores utilizaram 45 pré-molares hígidos nos quais foram preparadas cavidades tipo classe II MOD padronizadas, sendo que o limite cervical de uma das caixas proximais ficou $2 \mathrm{~mm}$ aquém da junção amelocementária e o limite cervical da outra caixa proximal ficou $2 \mathrm{~mm}$ além da junção amelo-cementária. Os dentes após serem preparados conforme os requisitos acima, foram divididos em 3 grupos de 15 dentes cada. Para o grupo I foi utilizado o sistema adesivo Scotchbond, para o grupo II o sistema adesivo Scotchbond Multi-Uso Plus e para o grupo III o sistema adesivo Primer \& Bond 2.0. Após a aplicação do sistema adesivo, seguindo-se a orientação dos respectivos fabricantes, os dentes foram restaurados com resina TPH (Dentisplay). Em seguida, os espécimes foram isolados com uma camada de araldite de presa rápida e uma camada de esmalte de unha de três cores diferentes, respeitando-se $2 \mathrm{~mm}$ das margens da restauração. Os espécimes foram 
armazenados por 24 horas em água a $37^{\circ} \mathrm{C}$ para serem submetidos a termociclagem 3 vezes ao dia por 5 vezes, permanecendo 5 minutos a $37^{\circ} \mathrm{C}, 5$ segundos a $5^{\circ} \mathrm{C}, 5$ minutos a $37^{\circ} \mathrm{C}$ e 5 segundos a $55^{\circ} \mathrm{C}$. O tratamento térmico foi realizado em 7 dias, sendo 15 ciclos diários, totalizando-se 105 ciclos. No intervalo entre as seqüências de 5 ciclos, os dentes foram mantidos em água a $37^{\circ} \mathrm{C}$ e no último dia, os 15 ciclos foram realizados em água previamente corada com fucsina básica a 0,5\%. Após a remoção da solução, os dentes foram secos ao ar livre e seccionados longitudinalmente em duas partes na direção mesiodistal, com disco de carburundum, sendo a avaliação feita por dois avaliadores, previamente calibrados, através de escores. A avaliação foi feita com uma lupa com aumento de 50 vezes. Os dados foram submetidos a uma análise estatística através do método de KruskalWallis. Quando o GI foi confrontado com GII e GIII, em relação ao esmalte, mostrou-se com maior grau de infiltração marginal. Quando confrontados os GII e GIII, verificou-se que eram semelhantes. Quando o GI foi confrontado, em relação à dentina, com o GIII mostrou-se com maior grau de infiltração marginal; já, quando confrontado com o GII, mostrou-se mais ou menos equivalente. Quando confrontados os GII e GIII, verificou-se que eram semelhantes. Os autores concluíram que para cavidades com paredes terminadas em esmalte o sistema adesivo do grupo II (Scotchbond Multi-Uso Plus) e o do grupo III (Primer \& Bond 2.0), têm boa capacidade de selamento marginal. Para cavidades 
com parede em dentina, o sistema adesivo do grupo III é o que proporcionou melhor resultado. Já o sistema adesivo do grupo I (Scotchbond) apresenta comportamento muito ruim, tanto para cavidades em esmalte quanto em dentina.

PIRES; PACHECO58 em 1998, realizaram um trabalho de revisão de estudos clínicos e laboratoriais, bem como descreveram um protocolo clínico para o novo material restaurador Ariston pHc (Vivadent). Os autores enumeraram as características do material como: estética; biocompatibilidade; protocolo clínico simplificado e rápido; liberação de flúor, cálcio e íons hidroxilas, proporcionalmente quando o pH da cavidade bucal aproxima-se do valor crítico. Também discutiram, com respaldo na literatura consultada, a possibilidade do material Ariston pHc inibir a cárie, reduzir a formação de placa e remineralizar a estrutura dentária através do cálcio e do flúor, além de neutralizar a ação dos ácidos com os íons hidroxilas. Além disso, descreveram e ilustraram um protocolo clínico simplificado, ressaltando, entretanto, que o tempo de experiência clínica é pequeno para conclusões definitivas, porém consideraram que se o protocolo clínico simplificado, as propriedades fisicas e o efeito neutralizador da liberação de íons cálcio, flúor e hidroxila forem confirmados em estudos de longo prazo, inicia-se uma nova era na Odontologia conservadora. 
YAP80 em 1998, estudou in vitro a influência do armazenamento em saliva artificial e da ciclagem térmica e mecânica sobre a microinfiltração de restaurações com o cimento de ionômero de vidro reforçado (Hi-Dense, Shofu) em preparos classe II com margem gengival $1 \mathrm{~mm}$ abaixo da junção esmalte-cemento. Os autores utilizaram 50 molares hígidos, recém extraídos, que depois de preparados de forma padronizada e restaurados, seguindo as normas do fabricante, foram armazenados em saliva artificial de $\mathrm{pH} 6,7$ a $37^{\circ} \mathrm{C}$ por uma semana, para então serem divididos em 5 grupos. No grupo I (controle), os dentes foram imersos no corante vermelho-neutro a $0,1 \%$, a $37^{\circ} \mathrm{C}$ por 24 horas; no grupo II os espécimes foram submetidos à termociclagem de 500 ciclos, nas temperaturas $10^{\circ} \mathrm{C} \pm 2{ }^{\circ} \mathrm{C}, 36^{\circ} \mathrm{C} \pm$ $1^{\circ} \mathrm{C}$ e $60^{\circ} \mathrm{C} \pm 1^{\circ} \mathrm{C}$, em banhos de duração de 4 segundos cada, realizados em uma máquina de termociclagem automática, sendo o tempo entre os banhos de 2s; no grupo III, os dentes foram submetidos a 1000 ciclos mecânicos com carga de $17 \mathrm{~kg}$ durante 0,5 minuto e depois imersos no corante vermelho-neutro a $0,1 \%$ por 24 horas a $37^{\circ} \mathrm{C}$. No grupo IV, o tratamento foi igual ao grupo I, entretanto os dentes foram previamente armazenados por 3 meses em saliva artificial a $37^{\circ} \mathrm{C}$ e no grupo $\mathrm{V}$, os dentes, após o armazenamento por 3 meses em saliva artificial a $37^{\circ} \mathrm{C}$, foram submetidos à ciclagem térmica igual à realizada no grupo II e a ciclagem mecânica igual à do grupo III, para então serem imersos no corante vermelho-neutro a $0,1 \%$ por 24 
horas a $37^{\circ} \mathrm{C}$. Todos os dentes foram seccionados no sentido mesiodistal, onde se produziam 4 secções. Foram avaliadas através de estereomicroscópio com aumento de 20 vezes, usando um sistema de escore.

Os autores concluíram que o selamento marginal de restaurações com o material Hi-Dense Shofu foi significantemente melhor no esmalte do que na dentina. A ciclagem térmica, mecânica e o armazenamento por 3 meses em saliva artificial, com ou sem ciclagem térmica e mecânica não influenciaram a microinfiltração na interface esmalte-dentina, porém na interface dentina-cemento a microinfiltração foi significantemente maior para todas as modalidades de tratamentos.

BARANSKA-GACHOWSKA; BORKOWSKI; ZIAJA6 em 1999, apresentaram um trabalho de um ano sobre a evolução clínica de restaurações com material Ariston pHc. Nesse trabalho foram realizadas 150 restaurações em dentes permanentes de adolescentes entre 16 e 20 anos, sendo 69 restaurações tipo classe I e 81 restaurações tipo classe II. As cavidades eram preparadas e preenchidas conforme recomendações do fabricante. Entretanto, contrariando as recomendações do fabricante, a parede pulpar das cavidades médias ou profundas foram cobertas por uma camada de base de cimento de ionômero de vidro Ketac-Molar. Em 74 dentes com 
cárie profunda foi aplicada uma base de hidróxido de cálcio, anterior ao preenchimento com o material Ariston pHc.

A avaliação clínica das restaurações foi realizada imediatamente após o término da restauração e depois de um ano. O critério usado para a avaliação incluiu forma anatômica, adaptação marginal, cárie secundária e lisura de superfície. Os resultados foram mensurados através de escores. Como o material é oferecido apenas na cor brancoopaco, o critério de coloração das restaurações foi abandonado.

Os autores concluíram que as restaurações em dentes permanentes de adolescentes com o material Ariston pHc após o período de observação de um ano foram aceitáveis e se os estudos longitudinais confirmarem esse achado inicial, o material pode tornarse uma alternativa estética às restaurações de amálgama.

CARE et al. ${ }^{15}$, em 1999, realizaram um estudo clínico com o objetivo de testar a eficácia de um novo material inibidor de cárie (Ariston pHc) durante o período de um ano, como uma alternativa para as restaurações de amálgama.

Para isso os autores realizaram, no período de outubro de 1997 até abril de 1998, 100 restaurações classe II e 50 classe I em 136 crianças selecionadas entre 4000 adolescentes de 10 escolas do estado de Latvia com idades entre 12 e 13 anos. O único critério de inclusão para essa seleção foi a presença de lesão de cáries, proximal ou 
oclusal, no primeiro ou segundo molar permanente e uma lesão semelhante no dente homólogo do mesmo arco.

O material experimental (Ariston $\mathrm{pHc}$ ) era aplicado de acordo com as instruções do fabricante, sendo em algumas cavidades mais profundas usada uma base de hidróxido de cálcio e para as restaurações de amálgama, os dentes eram preparados retentivamente usando-se a técnica de Black com, rotineiramente, uma base de cimento de ionômero de vidro (Ketac-Bond), utilizando-se instrumentos manuais para acabamento da caixa proximal.

Após um ano, dois dentistas calibrados examinaram as restaurações com auxílio de sonda exploradora e espelho. O critério foi definido com os seguintes passos: qualidade da margem; presença de fenda; descoloração; cáries secundárias; textura de superfície; sensibilidade ao ar ou aerosol frio; desgaste da restauração; fraturas e presença de trincas. Os observadores usaram para cada restauração a seguinte categoria de severidade: (a) bom; (b) aceitável e (c) não aceitável; sendo assim examinadas $86 \%$ das restaurações classe II e 90\% das restaurações classe I. Nenhum caso de hipersensibilidade no grupo experimental ou no grupo de amálgama (controle) foi relatado. Para ambas as restaurações, classe I ou classe II, fendas marginais foram observadas mais freqüentemente no grupo experimental que no grupo controle. Oito restaurações do grupo experimental (7 classe II e 1 classe I) mostraram desgaste comparado a 9 restaurações do grupo 
de amálgama; 5 restaurações do grupo experimental mostraram fratura comparada a 3 do grupo de amálgama. A lisura superficial do material Ariston pHc foi proporcionalmente maior que a do amálgama.

Os autores puderam concluir que após um ano as restaurações classe I e classe II do grupo experimental foram semelhantes às restaurações classe I e classe II do grupo controle. Eventualmente, se esses resultados continuarem após um maior intervalo de tempo, será possível afirmar que o material Ariston pHc é uma verdadeira alternativa para as restaurações posteriores de amálgama.

CARRARA ${ }^{17}$ (1999) realizou um estudo in vitro com o intuito de comparar a infiltração marginal nas paredes cervical e oclusal de cavidades classe $\mathrm{V}$ e a resistência ao cisalhamento dos materiais Chelon Fil, Vitremer, Compoglass-F e Z-100 em dentes decíduos. Para o teste de infiltração marginal, as cavidades foram preparadas na face vestibular de caninos decíduos extraídos, restauradas com os materiais acima, passando por ciclagem térmica de 500 ciclos nas temperaturas de $5^{\circ}$ e $55^{\circ} \mathrm{C}$. Os dentes foram imersos em solução de fucsina básica a $0,5 \%$ por 24 horas e seccionados para visualização da infiltração marginal nas paredes cervical e oclusal. Para o teste de resistência de união dos materiais ao esmalte, as faces vestibulares de dentes decíduos foram desgastadas com lixa de granulação 600, até se conseguir uma superficie plana de esmalte suficiente para se aderir os 
cilindros, com diâmetro de 2 milímetros, confeccionados com os materiais acima mencionados. Os corpos de prova foram levados à máquina universal de testes para a avaliação da resistência ao cisalhamento. Observou-se que o Chelon Fil apresentou maior grau de infiltração e menor resistência ao cisalhamento $(3,42 \mathrm{MPa})$ que os demais materiais. O Vitremer, o Compoglass-F e a Z-100 apresentaram infiltração semelhantes. O Chelon Fil e o Vitremer apresentaram infiltração maior na parede cervical que na oclusal, fenômeno este que não ocorreu com o Compoglass-F e a Z-100, que apresentaram infiltração semelhante em ambas as paredes. O Vitremer e o CompoglassF também foram semelhantes quanto à resistência ao cisalhamento, sendo de 9,02 $\mathrm{MPa}$ e 8,38 $\mathrm{MPa}$, respectivemante, porém seus valores foram menores que os $13,34 \mathrm{MPa}$ da resina composta Z-100.

FONTANA et al. ${ }^{29}$, também em 1999, realizaram um trabalho in vitro, utilizando um modelo artificial de microbiota bucal, com intuito de avaliar a eficácia na prevenção de cáries secundárias do material Ariston pHc. Para isso utilizaram dentes humanos divididos em quatro grupos, os quais foram restaurados com a resina composta Silux (com e sem a presença de fenda marginal, grupo I e II, respectivamente) ou com a resina composta Ariston pHc (Grupo III e IV, respectivamente com e sem a presença de fenda marginal), sendo inoculados e expostos 
a ciclos de 30 minutos em meio de cultura, três vezes ao dia e expostos posteriormente a uma solução mineral de limpeza, num total de vinte e duas horas e trinta minutos por dia, durante o período de sete dias.

Os resultados desse estudo sugerem que o grupo restaurado com a resina composta Ariston $\mathrm{pHc}$ em cavidades com fenda marginal foi o único grupo que em todos os seus espécimes não desenvolveu lesões de cárie nas paredes da cavidade e mostraram, também, que o uso da resina composta Silux em restaurações com fenda marginal apresentou os piores resultados dos quatro grupos avaliados. O melhor resultado foi verificado com o grupo III (Ariston pHc com fenda) em comparação ao grupo IV (Ariston pHc sem fenda).

Os autores concluíram que o fato de não haver nenhum efeito significante no conteúdo de flúor da resina composta Ariston pHc sobre o número de bactérias ou $\mathrm{pH}$, pode sugerir um possível efeito desse material em aumentar a resistência do esmalte ao ataque de cárie. Todavia, isso não explica porque há diferença entre os dois grupos restaurados com Ariston pHc, sendo possivel acreditar que a presença da fenda marginal ressalte o efeito protetor do Ariston pHc. Por fim, os autores sugerem o uso do material Ariston pHc em cavidades onde possa ocorrer a formação de fendas entre o material e a estrutura dentária, pois este se mostrou eficaz na prevenção do desenvolvimento de cáries secundárias. 
GALE; DARVELL ${ }^{32}$ em 1999, realizaram uma revisão da literatura para avaliar o número de ciclos utilizados em vários experimentos in vitro, com o objetivo de padronizar um regime único de ciclos que simulasse as condições bucais. Constataram, mediante a avaliação de 130 estudos laboratoriais, que a grande diferença entre o número de ciclos e as temperaturas usadas, como também os meios de testes e os corantes usados tornaram dificil a comparação dos resultados, que se apresentaram freqüentemente contraditórios; porém, na maioria da vezes, a microinfiltração aumenta com a pressão térmica. Os autores, então, sugeriram que uma padronagem nos processos de termociclagem era necessária e propuseram um regime cíclico padrão que seria de $35^{\circ} \mathrm{C}(28 \mathrm{~s}), 15^{\circ} \mathrm{C}(2 \mathrm{~s}), 35^{\circ} \mathrm{C}(28 \mathrm{~s})$ e $45^{\circ} \mathrm{C}(2 \mathrm{~s})$ em um meio de teste de saliva artificial (como desafio mínimo). Sugeriram, ainda, que para a simulação de um ano de serviço, a restauração deveria sofrer cerca de 10.000 ciclos como o acima citado; entretanto, não fizeram um trabalho de pesquisa para essas comprovações.

KIELBASSA; MÜLLER; GARCIA-GODOY46 em 1999, realizaram um trabalho in situ para avaliar o efeito de quatro diferentes tipos de materiais que liberam flúor na prevenção da cárie. Para isso utilizaram 22 molares humanos extraídos e sem cáries, dos quais foram preparados espécimes, da face lingual e vestibular, de mais ou menos 
$1 \mathrm{~mm}$. Os 44 espécimes foram divididos em quatro grupos, os quais foram restaurados segundo as indicações dos fabricantes. O primeiro grupo foi restaurado com Ariston pHc, o segundo com o compômero Dyract, o terceiro com cimento de ionômero de vidro modificado por resina Vitremer e o quarto grupo com cimento de ionômero de vidro convencional Ketac-Molar. Os espécimes foram adaptados em aparelhos ortodônticos inferiores com quatro espécimes cada (representando os 4 grupos) para serem utilizados por 11 indivíduos durante todo o dia e noite, por 4 semanas. Os espécimes foram seccionados para avaliação através das restaurações e nas proximidades das mesmas $(5 \mathrm{~mm})$. Microradiografias das secções foram obtidas e estudadas através de um sistema de análise digital, sendo que o cálculo do conteúdo mineral das imagens scaneadas foi realizado através de um software específico (TMR 1.24).

No presente estudo, ambos os cimentos de ionômero de vidro (Vitremer e Ketac-Molar) mostraram uma tendência de inibir a desmineralização, ao contrario do compômero Dyract. Esses resultados estão em concordância com artigos publicados previamente na literatura, os quais mostram que os efeitos de inibição da desmineralização só podem ser vistos em materiais que possuam uma alta liberação de flúor.

Segundo os autores, entretanto, uma redução significante de cárie pôde ser observada apenas no grupo do material Ariston pHc, 
sugerindo que os materiais restauradores que tentam prevenir a cárie dentária devam ter adição de ambos os íons, de flúor e de hidroxila. Em conclusão, consideraram que os cimentos de ionômero de vidro assim como os compômeros mostraram um pobre beneficio na inibição da cárie, sendo os materiais que contêm adição de íons hidroxila uma alternativa para as novas restaurações. Desta maneira, segundo os autores, a opinião de que o cimento de ionômero de vidro possui um pobre efeito anticariogênico nas investigações clínicas, foi confirmado por este estudo.

LIM; NEO; YAP49 (1999) compararam o efeito do acabamento imediato com o acabamento após uma semana sobre a microinfiltração do cimento de ionômero de vidro modificado por resina (Fuji II LC) e o compômero (Dyract) em margens de dentina e esmalte, comparando a diferença entre os grupos e entre as margens. Para isso, os autores padronizaram cavidades classe V (largura mesio-distal de $3 \mathrm{~mm}$, ocluso-gengival de $2 \mathrm{~mm}$ e profundidade axial de $2 \mathrm{~mm}$ ) realizadas junto à junção esmalte/cemento nas superfícies vestibular e lingual de 24 pré-molares hígidos, extraídos e armazenados em água destilada, mantendo-se metade das margens da cavidade no esmalte e metade na dentina. Os 24 dentes foram divididos em 4 grupos, sendo que no grupo I (Fi) foi utilizado o ionômero de vidro Fuji II LC, com acabamento imediato; no grupo II (Di), o compômero Dyract com 
acabamento imediato; no grupo III (Fd) e grupo IV (Dd), o Fuji II LC e o Dyract, respectivamente, com acabamento após uma semana. Os espécimes do grupo III e IV tiveram suas restaurações realizadas uma semana antes e foram armazenados em soro fisiológico a $37^{\circ} \mathrm{C}$ para que recebessem o acabamento no mesmo dia dos espécimes do grupo I e II. Após as restaurações, os espécimes foram submetidos à termociclagem de 500 ciclos, permanecendo $2 \mathrm{~s}$ a $5^{\circ} \mathrm{C}, 10 \mathrm{~s}$ a $34^{\circ} \mathrm{C}$ e $2 \mathrm{~s}$ a $65^{\circ} \mathrm{C}$. Os ápices foram selados com cera utilidade e aplicados em suas raízes duas camadas de verniz, respeitando-se $1,5 \mathrm{~mm}$ das margens da restauração. Em seguida, foram imersos em fucsina básica a $0,5 \%$ por 24 horas a $37^{\circ} \mathrm{C}$. Após a remoção da solução, os dentes foram secos e seccionados longitudinalmente em duas partes no sentido vestíbulo-lingual, sendo a avaliação feita por dois avaliadores, através de escores, com um estereomicroscópio, com um aumento de 40 vezes. Os dados foram submetidos à análise estatística de variância de Kruskal-Wallis, inicialmente para avaliar os materiais, que demonstrou haver uma diferença estatisticamente significante entre $\mathrm{Fi}$ e Fd, sendo Fi maior, o que não ocorreu entre os grupos Di e Dd. Para avaliar a microinfiltração entre as margens em esmalte e dentina foi utilizada a análise de variância de Fridman que mostrou uma microinfiltração maior nas margens de dentina para ambos os regimes de acabamento (exceto para o grupo IV (Dd)). Os autores concluíram que para o Dyract, o acabamento das restaurações com 
margem terminando em esmalte ou em dentina pode ser realizado imediatamente, enquanto que para o Fuji II LC, o acabamento das restaurações com margens em dentina pode ser imediato, porém, para as cavidades com margens em esmalte o acabamento deve ser adiado.

OLIVEIRA $^{54}$ em 1999, avaliou in vitro a microinfiltração das restaurações com um sistema adesivo/resina composta (Glacier) e das associações de compômeros (Freedom, F-2000, Dyract) ou cimento de ionômero de vidro modificado por resina (Vitremer) com resina composta em cavidade de classe II amplas (MOD) com margem cervical $1 \mathrm{~mm}$ abaixo ou acima da junção amelo-cementária. Foram realizados 110 preparos em pré-molares e molares hígidos, extraídos e submetidos ao condicionamento prévio do esmalte e dentina, com exceção do grupo do Vitremer. Os espécimes foram divididos em 5 grupos: no grupo 1, as cavidades foram restauradas apenas com resina composta Glacier; no grupo 2, as cavidades foram restauradas pela técnica mista, em que foi associado o Vitremer à resina Glacier; nos grupos 3, 4, e 5 (grupos experimentais), as cavidades foram restauradas pela técnica mista, associada aos compômeros Dyract, F2000 e Freedom, respectivamente Foi utilizada uma matriz metálica e os compômeros e o cimento de ionômero de vidro modificado por resina foram inseridos nas margens cervicais das caixas proximais até a parede pulpar, sendo em seguida polimerizados em várias direções. 
Os materiais foram desgastados, mantendo uma espessura de $2 \mathrm{~mm}$. As restaurações foram completadas com a utilização dos sistemas adesivos/resina composta (técnica mista). A avaliação da área infiltrada, dos dentes seccionados após ciclagem mecânica, foi realizada através da penetração do corante fucsina a 0,5\%. Os resultados demonstraram que os dentes restaurados com a associação Vitremer/resina composta apresentaram menores áreas infiltradas nas margens cavitárias de esmalte em comparação com as demais associações de materiais utilizadas. As restaurações com as associações compômeros/resina, embora com resultados inferiores aos observados com a utilização do sistema adesivo/resina composta, apresentaram menores áreas infiltradas nas margens cavitárias em esmalte. Por meio da análise estatística, a autora concluiu que as margens em esmalte apresentaram, independentemente dos materiais utilizados, menores áreas infiltradas e as margens cavitárias em esmalte e dentina das restaurações com a associação de Vitremer/resina apresentaram as menores áreas infiltradas.

SCHIFFNER ${ }^{65}$ em 1999, realizou um estudo em boca artificial, onde avaliou a inibição da desmineralização em esmalte e dentina conseguida através da utilização do material Ariston pHc. Para isso utilizou 24 terceiros molares extraídos cirurgicamente os quais foram limpos e cortados ao meio. Em cada metade foi obtido um espécime 
para estudo. Com intuito de produzir fendas marginais, pequenos pedaços de matriz metálica eram inseridos nas margens apical e coronal da cavidade, anteriormente a sua restauração. Metade dos espécimes obtidos (24) foram restaurados com material Ariston pHc e a outra metade restaurada com a resina composta Tetric. $\mathrm{Na}$ boca artificial os espécimes sofreram a indução da formação de lesão de cárie sobre o esmalte e a dentina. Após o período de seis semanas os espécimes foram avaliados através de microscópios de luz polarizada com aumento de 50 vezes.

Os resultados mostraram a capacidade do material Ariston pHc em inibir a desmineralização do esmalte e da dentina. Esse efeito é devido à troca de íons de flúor e hidroxilas, quando a restauração é submetida ao baixo $\mathrm{pH}$. Por neutralizar os ácidos produzidos pelas bactérias e promover uma remineralização, essa troca iônica fornecerá um ambiente menos favorável para o desenvolvimento do S. mutans.

Os autores concluíram, com os resultados deste estudo in vitro, que o material Ariston pHc foi capaz de reduzir a desmineralização do esmalte e dentina tanto em situações com boa adaptação marginal quanto em situações onde existam fendas marginais entre o material restaurador e a estrutura dentária.

TRUMMLER; MÜLLER; WEISS73 em 1999, descreveram suas experiências clínicas com o novo material restaurador Ariston pHc em 
dentes decíduos através de um estudo, no qual foram realizadas 34 restaurações classe II em primeiro molares de crianças entre 6 e 10 anos, sendo avaliadas após um ano. Para a realização dessas restaurações não foi utilizado o dique de borracha, sendo os dentes isolados apenas com rolos de algodão e prendedor de língua, sendo que em alguns casos foram utilizadas matrizes de aço em conjunto com cunhas de madeira. As restaurações receberam polimento final com brocas diamantadas e discos Sof-Lex. As restaurações foram avaliadas, por dois experientes dentistas, imediatamente após a restauração e após o período de um ano através dos seguintes critérios: hipersensibilidade; descoloração da restauração; contraste de cor entre o material e a estrutura dentária; cáries secundárias e desempenho geral da restauração. Os resultados, após um ano, não demonstraram cáries secundárias nem hipersensibilidade. O contraste entre o material restaurador e a estrutura dentária adjacente mostrouse excelente após o período de um ano, não sendo detectada descoloração da restauração.

Os autores concluíram que, após um ano de uso, os resultados das restaurações tipo classe II com o material Ariston pHc em molares decíduos foram bastante favoráveis, podendo esse material ser ideal para uso em molares decíduos, especialmente devido a sua facilidade de manipulação, caso os resultados se mantenham por mais tempo. Consideraram, ainda, o material Ariston pHc apropriado para 
restaurações em dentes decíduos anteriores, especialmente em cáries do tipo rampantes.

VIEIRA, et al. ${ }^{74}$ (1999) avaliaram in vitro a infiltração marginal em cavidades classe $\mathrm{V}$ de molares permanentes, restauradas com um ionômero de vidro modificado por monômero resinoso (Vitremer) e duas resinas compostas modificadas por poliácidos (Compômeros Dyract e Compoglass). Utilizaram 30 terceiros molares permanentes hígidos, que estiveram armazenados em água em refrigerador, até seu uso. As cavidades foram confeccionadas com brocas 1034 com as seguintes dimensões: ocluso-cervical de $3 \mathrm{~mm}$, mesio-distal de $3 \mathrm{~mm}$, profundidade de $1 \mathrm{~mm}$ e a margem cervical localizada $1 \mathrm{~mm}$ em dentina/cemento. Foram realizadas 60 cavidades divididas em 3 grupos com 10 dentes e 20 cavidades cada. O grupo I foi restaurado com Vitremer, o grupo II com Dyract e o grupo III com Compoglass, sendo as técnicas de preenchimento das cavidades, polimerização e acabamento, aquelas preconizadas pelos respectivos fabricantes. Os espécimes foram armazenados por 7 dias em água à temperatura ambiente e depois sofreram termociclagem de 200 ciclos. Cada ciclo consistia de 60 s, permanecendo 10 s a $55^{\circ} \mathrm{C}, 20$ s a $5^{\circ} \mathrm{C}, 10 \mathrm{~s}$ a $55^{\circ} \mathrm{C}$ e finalmente $20 \mathrm{~s}$ a $5^{\circ} \mathrm{C}$. Os ápices foram restaurados com resina epóxica Araldite e os dentes recobertos com esmalte para unhas, respeitandose $1 \mathrm{~mm}$ ao redor da restauração, para então serem imersos durante 24 
horas em fucsina básica e depois foram lavados durante 5 minutos em água corrente. Foram, então, seccionados no sentido longitudinal e vestíbulo-lingual com disco diamantado de dupla face, refrigerado a água e em baixa rotação. A análise da infiltração foi feita com uma lupa estereoscópica com aumento de 25 vezes através de escores, sendo realizada por três observadores, previamente calibrados. Os dados foram submetidos a uma análise estatística pelos testes de Kruskal-Wallis e Mann-Wintney. Os resultados encontrados não mostraram diferenças estatisticamente significantes na infiltração entre os grupos, quer entre as paredes ou entre os materiais utilizados. Os autores concluíram que o ionômero de vidro modificado (Vitremer) e as duas resinas compostas modificadas por poliácidos (Dyract e Compoglass) apresentaram algum grau de infiltração marginal; entretanto, não houve diferença estatisticamente significante entre os materiais estudados, independente da localização da parede cervical ou oclusal das cavidades.

BRAUN et al. ${ }^{8}$, em 2000, realizaram um estudo clínico controlado com a finalidade de analisar o selamento marginal de duas resinas compostas, após 6 meses. Os autores avaliaram a resina composta Solitaire (Heraeus-Kulzer) e a resina composta modificada Ariston pHc (Vivadent) que procura controlar a fenda marginal através da liberação de flúor e íons cálcio; portanto, não utiliza adesivo de união, exceto um 
"liner" para o selamento dentinário. Nesse estudo, 31 pacientes receberam 99 restaurações realizadas por 7 operadores. Devido à baixa adesão do material Ariston pHc, retenções mecânicas adicionais foram realizadas. Imediatamente às restaurações e após 6 meses, foram realizadas moldagens para obtenção dos modelos das restaurações. Um total de 40 amostras representativas (20 Ariston e 20 Solitaire, sendo 5 classe I e 35 classe II) foram avaliadas através de microscópio, associado a uma câmera colorida com aumento de 130 vezes. Os resultados obtidos, após a realização do teste estatístico de Freedman e 2-way ANOVA em nível de 5\% de significância, serviram para os autores concluírem que após 6 meses não houve diferença estatisticamente significante entre os materiais; como também ressaltaram que a característica de formação de fenda marginal do material Ariston pHc é devido a sua baixa adesividade, enquanto que o material Solitaire apresentou uma característica de formação de degrau negativo, obviamente devido sua menor resistência ao desgaste.

Com o propósito de avaliar algumas técnicas de inserção de resina composta em cavidade classe II com relação à infiltração marginal, DOMINGUES et al. ${ }^{27}$ (2000) realizaram um trabalho no qual foram utilizados 30 pré-molares, sendo confeccionadas duas cavidades proximais em cada dente, com margem cervical em esmalte. Os blocos foram divididos em grupos assim distribuídos: grupo 1 utilizou a 
técnica de inserção em bloco único mais a resina fotopolimerizavél Z-100; grupo 2, a técnica de inserção incremental de Lutz mais a resina Z-100; grupo 3, a técnica de inserção por contração dirigida mais um primeiro incremento de resina autopolimerizável Bisfill II, mais o término da restauração com resina Z-100 pela técnica de incrementos. Os dentes foram armazenados em estufa a $37^{\circ} \mathrm{C}$ por 24 horas. Em seguida, foi feito o acabamento e o polimento das restaurações com um disco Sof-Lex, o seccionamento do ápice articular, a condensação apical de amálgama, o vedamento com Araldite do ápice radicular, o vedamento de todo o dente com duas camadas de esmalte, exceto por $1 \mathrm{~mm}$ aquém das margens da restauração. $\mathrm{Na}$ ciclagem térmica, foram utilizados 200 ciclos a $5^{\circ} \mathrm{C}$ e $55^{\circ} \mathrm{C}$ alternadamente, permanecendo 15 segundos em cada banho. Os dentes foram imersos em fucsina básica a $0,5 \%$ e rearmazenados em estufa a $37^{\circ} \mathrm{C}$ por 24 horas. Após esse período os espécimes foram lavados por 6 horas, raspados e secos. Posteriormente, foram incluídos em resinas poliestirênica e seccionados em cortes de aproximadamente 0,5mm de espessura. Os resultados foram submetidos à análise estatística pelo teste de Kruskal-Wallis e não foi perceptível diferença significante entre os grupos ao nível de 5\%, entretanto, ao nível de $10 \%$, o grupo 2 obteve resultados mais favoráveis, mostrando que a técnica de inserção incremental de Lutz se mostrou a mais promissora entre as testadas. 
GOMES; CAVINA; GOMES ${ }^{35}$ em 2000, descrevem a aplicação de uma nova resina composta para dentes posteriores com propriedades de controle do $\mathrm{pH}$ através do intercâmbio de íons $\left(\mathrm{Ca}^{++}, \mathrm{F}^{-}\right.$e $\left.\mathrm{OH}-\right)$, nas áreas ao redor das restaurações. Nele, os autores citam as características do liner cavitário fotopolimerizável (Ariston liner) que acompanha o material e possui a finalidade de dessensibilizar a estrutura dentária, evitando a presença de sensibilidade pósoperatória. Citam também, as características do material restaurador (Ariston pHc), de cor branca, fotopolimerizável e indicado para dentes permanentes posteriores e decíduos. Tal material apresenta como uma de suas propriedades a liberação de íons quando o $\mathrm{pH}$ atinge valores críticos para a estrutura dentária, inibindo assim a desmineralização e o crescimento bacteriano, neutralizando os ácidos produzidos pelas bactérias cariogênicas presentes na placa bacteriana e promovendo a remineralização da estrutura dentária.

Os autores, ainda descrevem a técnica restauradora ressaltando a necessidade de ângulos internos arredondados e cavidades autoretentivas, afirmando que o material é de fácil utilização e rápido protocolo. Ressaltam também, que apesar da sua cor, branco-opaco, o grau de satisfação dos pacientes foi bom, principalmente devido ao efeito camaleônico da região posterior onde o brilho dos materiais e da saliva, pela transmissão de luz, produz um mimetismo, mascarando as diferenças de cor a uma distância de conversação. 
Em resumo, os autores concluem que a liberação de íons flúor, cálcio e hidroxila parece ser o grande diferencial desse material. Segundo eles, se forem confirmados os resultados obtidos até o presente momento, através de estudos a longo prazo, estaremos diante de uma nova era na odontologia restauradora, onde não bastará devolver a função ao elemento dentário sem oferecer condições, ainda que o paciente não colabore, de uma autodefesa em caso de nova ação das bactérias cariogênicas. 
3 - Proposição 


\section{3 - PROPOSIÇÃO}

O presente trabalho se propõe a avaliar in vitro a microinfiltração marginal em restaurações classe II, realizadas com um cimento de ionômero de vidro modificado por resina, uma resina composta "semicondensável" e uma resina composta "condensável", com o propósito de verificar:

$\checkmark$ Resultados de microinfiltração obtidos com os três materiais, comparando-os entre si;

$\checkmark \quad$ A influência da ciclagem térmica, na microinfiltração marginal para esses materiais;

$\checkmark$ Dois métodos de análise da penetração do corante para avaliação da microinfiltração marginal. 
4 -Material e Métodos 


\section{4 - MATERIAL E MÉTODOS}

4.1 - Material

Neste experimento foram selecionados cento e vinte faces proximais de sessenta dentes pré-molares humanos, hígidos, extraídos por indicação ortodôntica. Após a exodontia, os dentes foram limpos com escovas tipo Robinson, pedra pomes e água, para a remoção de detritos e restos de ligamento periodontal e armazenados a uma temperatura de $\pm 5^{\circ} \mathrm{C}$, em solução de $\mathrm{NaCl}$ a $0,9 \%$ com timol a $0,01 \%^{a}$, com a finalidade de inibir o crescimento bacteriano, até o momento dos testes.

Para execução deste experimento foram empregados três materiais restauradores, a saber: um cimento de ionômero de vidro modificado por resina VITREMERTM b (GI - controle - Figura 1); uma resina composta "semicondensável" ARISTON pHcc (GII - Figura 2) e uma resina composta “condensável” Filtek ${ }^{\mathrm{TM}}$ P-60d (GIII - Figura 3). Os materiais utilizados foram agrupados na figura 4, de acordo com lote, fabricante e composição destes materiais.

\footnotetext{
a Fornecido pelo Departamento de Bioquímica - FOB/USP

b $3 \mathrm{M}$ Dental Products. St. Paul, MN., USA / cor A3

c Vivadent Ets. Schaan. Liechtenstein

d 3M Dental Products. St. Paul, MN. USA / $\operatorname{cor} \mathrm{C}_{2}$
} 


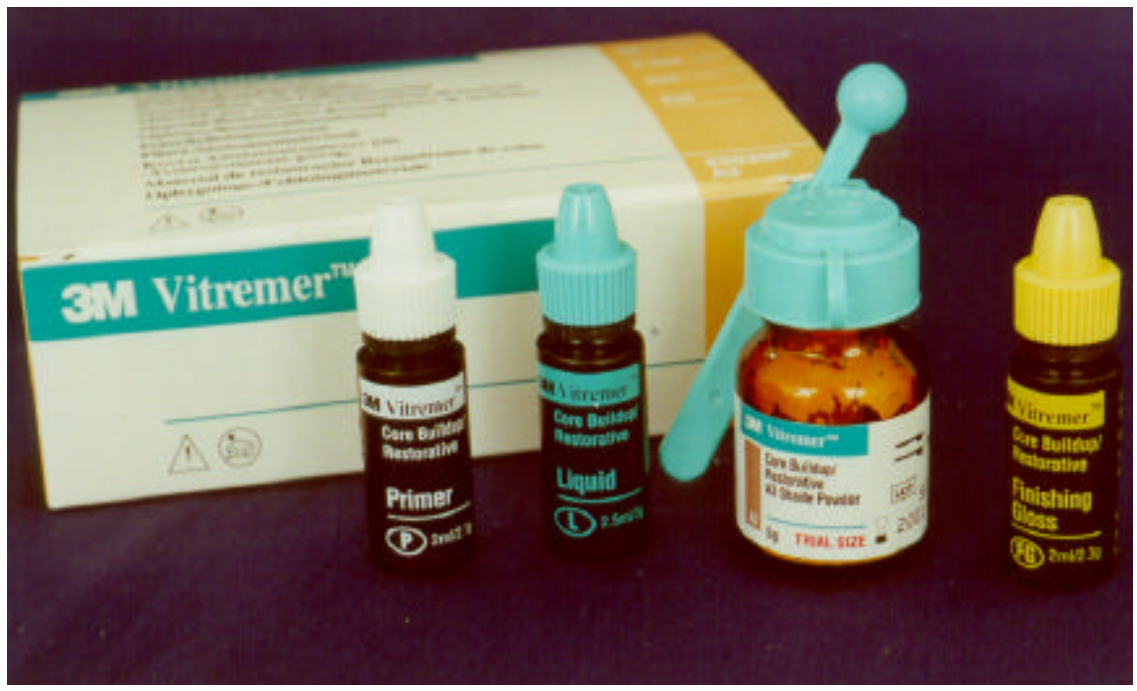

Figura 1: Cimento de ionômero de vidro modificado por resina VITREMERTM $^{\mathrm{T}}$ (GI)

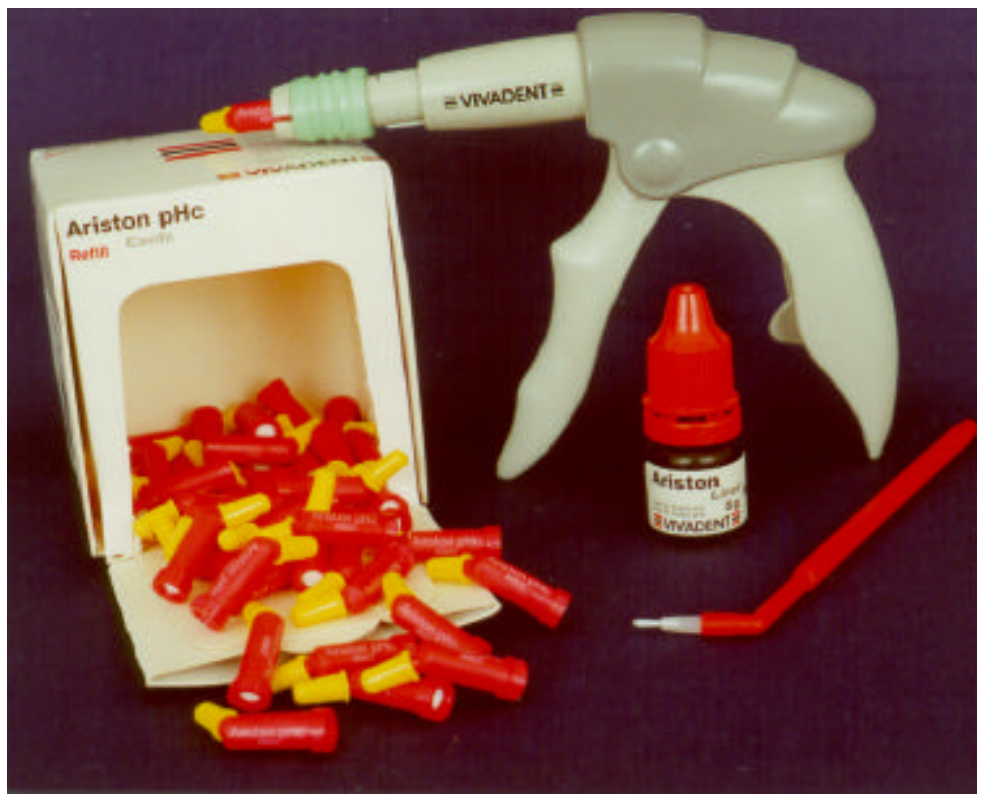

Figura 2: Resina composta "semicondensável" ARISTON pHc (GII)

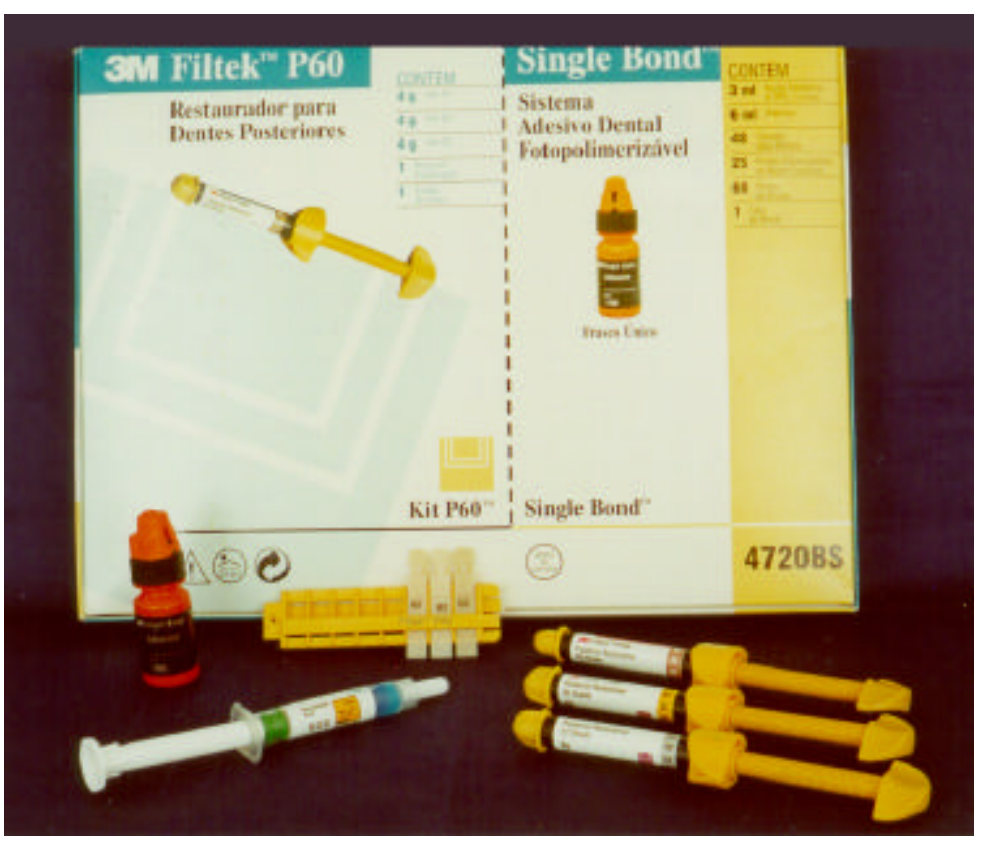

Figura 3: Resina composta “condensável" Filtek ${ }^{\mathrm{TM}} \quad$ P-60 (GIII) 


\begin{tabular}{|c|c|c|c|}
\hline MATERIAL & LOTE & FABRICANTE & COMPOSIÇÃO \\
\hline Vitremer & 9172 & 3M Dental Products & $\begin{array}{l}\text { "Primer": copolímero de } \\
\text { policarboxílico, HEMA, álcool etílico. } \\
\text { Pó: cristais de fluoralumínio silicato. } \\
\text { Liquido: solução aquosa de ácido } \\
\text { polialquenóico modificado, sensivel à luz. } \\
\text { "Glaze": resina fotopolimerizável } \\
\text { GMA/TEGDMA), sem carga e unifásica. }\end{array}$ \\
\hline Ariston & A25483 & $\begin{array}{c}\text { Vivadent Ets. } \\
\text { Schaan }\end{array}$ & $\begin{array}{l}\text { Ariston "Liner": ácido poliacrílico modificado } \\
\text { por metacrilato, HEMA, ácido maleico, } \\
\text { catalisadores e estabilizadores em uma } \\
\text { solução de água e etanol. } \\
\text { Ariston pHc: matriz de monômero de } \\
\text { diferentes tipos de dimetacrilato, vidro de } \\
\text { fluorsilicato de bário e aluminio, fluoreto de } \\
\text { itérbio e dióxido de silício altamente } \\
\text { disperso, catalizadores e pigmentos. }\end{array}$ \\
\hline P-60 & 23109 & 3M Dental Products & $\begin{array}{l}\text { Condicionador: ácido fosfórico a 37\%. } \\
\text { Adesivo: Single Bond 3M, copolimeros dos } \\
\text { ácidos poliacrílico e politacônico, sistema } \\
\text { fotoiniciador, dimetacrilatos, HEMA e Bis- } \\
\text { GMA em uma solução de água e álcool. } \\
\text { P-60: "filler" formado por Zircônia/Sílica, } \\
\text { matriz orgânica formada por Bis-GMA, } \\
\text { UDMA e Bis-EMA com matriz inorgânica de } \\
\text { 61\% por volume (sem silano). }\end{array}$ \\
\hline
\end{tabular}

Figura 4: Quadro de relação dos material utilizado, seguido de lote, fabricante e composição dos mesmos. 
4.2 - Métodos

Os 60 dentes foram removidos da solução de armazenamento anteriormente citada, lavados abundantemente em água corrente e divididos aleatoriamente, em 3 grupos contendo 20 pré-molares cada (40 cavidades), num total de 120 cavidades.

Primeiramente, em cada ápice radicular foi confeccionada uma cavidade retentiva com uma ponta diamantada cone invertido n. ${ }^{\circ}$ 1031e a qual foi restaurada com amálgama Velvalloyf

Cavidades proximais, do tipo classe II modificadas, ("slot" vertical) com envolvimento da crista marginal foram preparadas nas faces mesiais e distais de todos os dentes, de maneira que cada grupo era composto de quarenta faces proximais.

Os preparos cavitários foram realizados com brocas de aço do tipo carbide n. $^{\circ} 245 \mathrm{~g}$ usadas em turbinas de alta rotaçãoh ${ }^{h}$ sob refrigeração constante de um "spray" de água e ar. Cada broca foi usada para fazer cinco preparos. O acabamento das cavidades foi realizado com a mesma broca em baixa rotação e o recortador de margem cervical $n .^{\circ} 27 \mathrm{j}$, permitindo assim uma cavidade de paredes e tamanho mais regulares. As

e KG Sorensen Ind. Com. Ltda. Bauru, SP / Brasil

f SSWhite Artigos dentários Ltda. Rio de Janeiro, RJ / Brasil

g KG Sorensen Ind. Com. Ltda. Bauru, SP / Brasil

h Alta Rotação PS 300 - Dabi Atlante SA. Ribeirão Preto, SP / Brasil

i Micro-motor SR e Contra-angulo Standard - Dabi Atlante SA. Ribeirão Preto, SP / Brasil

j Duflex Artigos dentários 
cavidades tipo classe II "slot" vertical foram padronizadas com $4 \mathrm{~mm}$ de largura vestíbulo-lingual e $1 \mathrm{~mm}$ de profundidade na região da parede gengival. A parede cervical estendeu-se $1 \mathrm{~mm}$ além da junção cemento-esmalte para que o ângulo cavo-superficial terminasse em cemento, isto porque é sabido ser esta uma área crítica em relação à infiltração marginal (Figura 5).

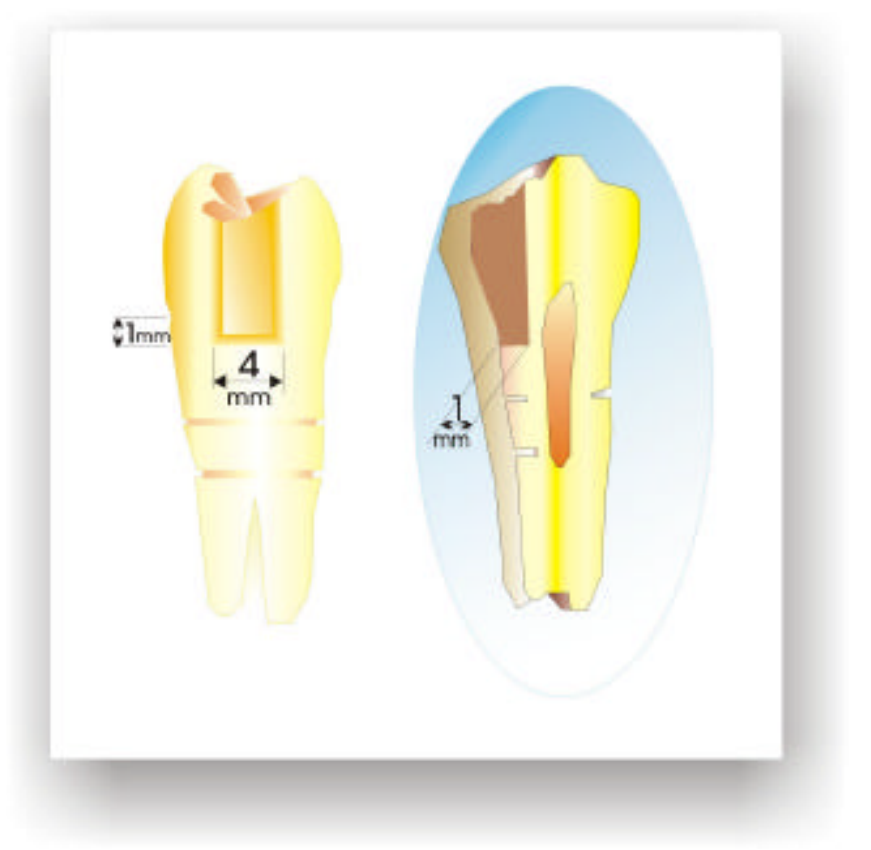

Figura 5: Medidas utilizadas para a confecção das cavidades

Com o uso da broca $n .^{\circ} 245$, conseguiu-se todos os ângulos internos da cavidade arredondados. Terminado o preparo, a cavidade foi lavada com jatos de água e seca suavemente com jatos de ar, sem, entretanto, desidratar excessivamente a superficie dentinária. (Figura 6). 


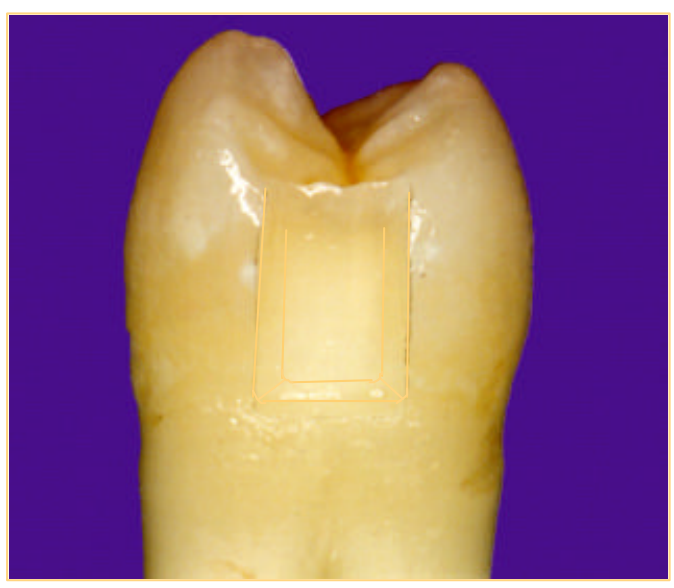

Figura 6: Preparo terminado

A fim de receber as restaurações, cada dente foi montado no centro de um bloco de gesso pedrak que continha em seu interior um rolete de cera rosa $n .^{\circ} 7^{1}$, facilitando assim a sua inserção e remoção, sendo ladeado por dois dentes do tipo pré-molares íntegros, na tentativa de reproduzir os pontos de contatos proximais da melhor maneira possivel. Os blocos foram de tamanho préestabelecido e compativel com as necessidades do experimento

Utilizaram-se matrizes pré-fabricadas de poliésterm $^{m}$ para prémolares, devidamente adaptadas e estabilizadas ao dente por cunhas reflexivas $^{n}$, para a obtenção do contorno da restauração na tentativa de uma melhor adaptação e polimerização do material (Figura 7). O aparelho de luz fotopolimerizadora utilizado foi o Optilight $600^{\circ} \mathrm{com}$ intensidade de luz de $450 \mathrm{~mW} / \mathrm{cm}^{2}$, aferida com auxilio do radiômetro do próprio fabricante.

\footnotetext{
k Herodent - Vigodent. Rio de Janeiro / Brasil

1 Problem - Lab. Prod. Farm. e Odont. Ltda. Catanduva, SP / Brasil

m TDV Dental - Pomedore

n TDV Light Cure System / TDV Dental - Pomedore

${ }^{\circ}$ GNATUS Equipamentos médico-odontológicos Ltda. Ribeirão Preto, SP / nº 350253
} 


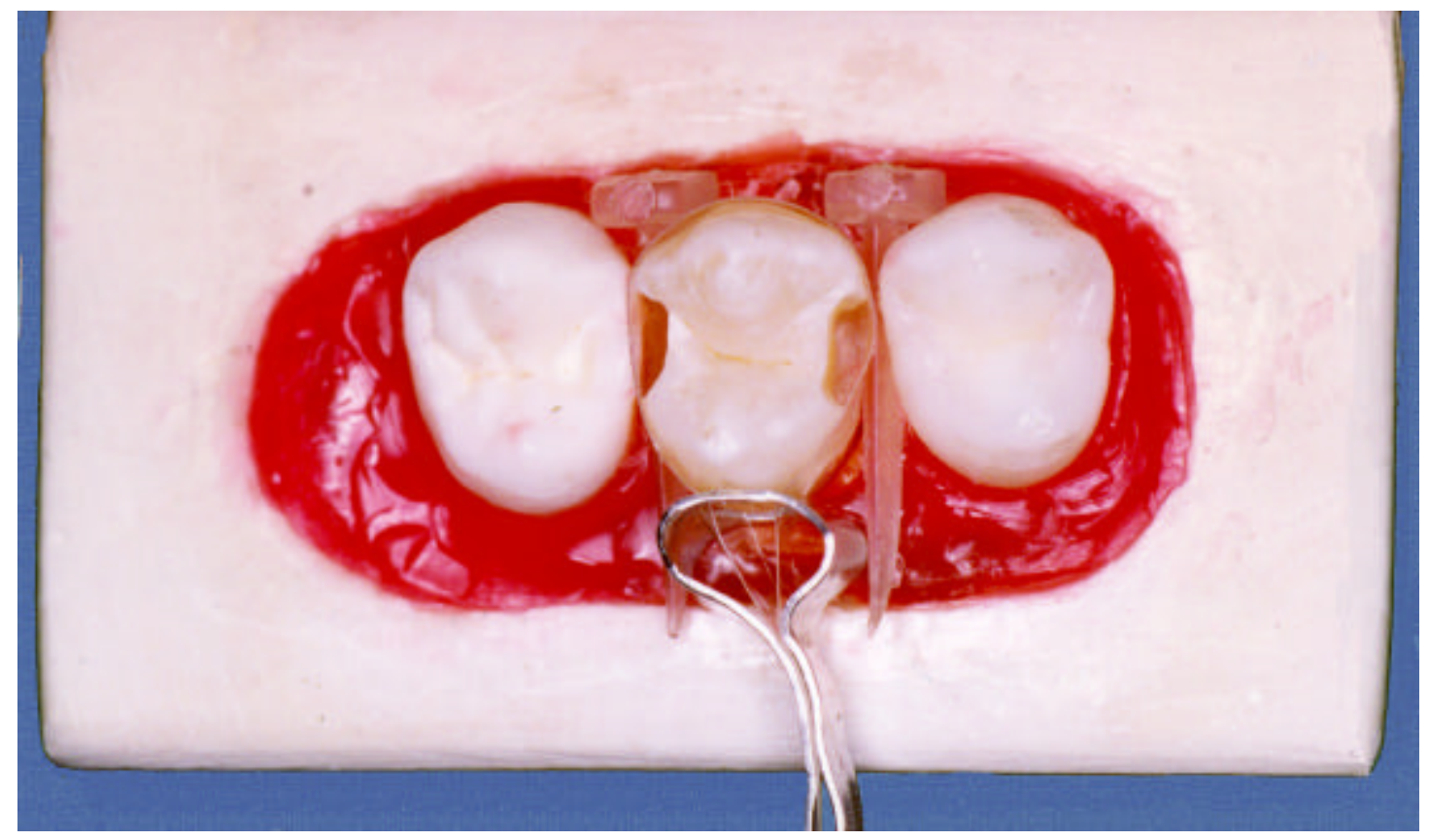

Figura 7: Dentes incluídos em bloco de gesso, com matriz e cunhas posicionadas

Todos os materiais foram manipulados de acordo com as instruções do fabricante. Para o material cuja manipulação foi realizada através da mistura pó/líquido tomou-se os seguintes cuidados: a gota foi dispensada com o frasco na vertical a uma distância aproximada de $5 \mathrm{~cm}$ da placa de vidro, desprezando sempre a gota que possuísse bolhas de ar, o que alteraria o seu tamanho; o frasco de pó foi sempre agitado antes da retirada do material; a gota do líquido e a porção de pó, eram colocadas sobre o bloco no momento da espatulação para se evitar qualquer contaminação pelo ambiente.

Os grupos estudados foram divididos do seguinte modo: 
Grupo I (G I - controle) VITREMER:

Neste grupo as quarenta cavidades foram restauradas com o ionômero de vidro modificado por resina Vitremer. Após serem lavadas abundantemente com água e secas levemente com jatos de ar, as cavidades receberam aplicação do "primer" por 30 segundos. Em seguida, secou-se com jato de ar por 15 segundos e fotopolimerizou-se durante 20 segundos. A proporção pó/líquido utilizada para a confecção de uma restauração foi $1: 1$. 0 material foi manipulado com espátula plástica, sendo que todo o pó foi incorporado ao líquido em 45 segundos. 0 mesmo foi inserido na cavidade em uma única vez com seringa Centrix C-Rp, cuja ponta era mantida imersa no material na tentativa de se evitar a incorporação de bolhas.

Utilizou-se um condensadorq para adaptar suavemente o material. Após a inserção da mistura, foi feita a fotopolimerização por 40 segundos através da cunha e mais 40 segundos através da superficie oclusal.

Grupo II (G II) - ARISTON:

Neste grupo, as quarenta cavidades foram restauradas com a resina

p Centrix Incorp., Stratford, CT / USA

q Hu-Friedy Goldstein p/ composto cd. n.1 CI0145 
composta "semicondensável" Ariston. Após as cavidades serem lavadas abundantemente com jatos de água e secas levemente com jatos de ar, pincelou-se Ariston "liner" no interior da cavidade deixando-o atuar e reagir durante 20 segundos; a seguir, aplicou-se novamente uma fina camada de Ariston "liner" que foi espalhada com o jato de ar até que não fosse mais possivel perceber o "movimento" do líquido para então fotopolimeralizá-lo durante 20 segundos. Para a confecção da restauração aplicou-se Ariston pHc em pequenas camadas $(+2 \mathrm{~mm})$ utilizando-se, com o auxílio de um condensador para compósito, a técnica incremental da seguinte maneira: primeiramente, inseriu-se uma camada horizontal e fotopolimerizou-se através da cunha por 40 segundos; colocou-se, então, uma segunda camada de igual espessura na diagonal, apoiando-se na parede lingual e fotopolimerizou-se através desta parede; por fim, uma terceira camada foi inserida para o preenchimento completo do preparo e este foi fotopolimerizado através da parede vestibular também por 40 segundos.

Grupo III (G III) - P-60:

Neste grupo, as quarenta cavidades receberam a resina composta "condensável" Filtek ${ }^{\mathrm{TM}}$ P-60. Para isto, aplicou-se o ácido de ataque, Scotchbond, ao esmalte e dentina por 15 segundos e 
após o enxágue, o excesso de água foi retirado, deixando-se a superfície levemente úmida. Utilizando uma ponta de pincel saturada para cada cobrimento, aplicaram-se duas camadas consecutivas do adesivo Single Bond ao esmalte e dentina, secou-se, levemente, por 2 a 5 segundos e fotopolomirizou-se por 10 segundos. A inserção do material restaurador Filtek ${ }^{\mathrm{TM}} \mathrm{P}-60$ na cavidade, com auxílio do condensador para compósito, foi realizada também pela técnica incremental da seguinte maneira: primeiramente, inseriu-se uma camada inferior a $2,5 \mathrm{~mm}$ de maneira horizontal e fotopolimerizou-se através da cunha por 20 segundos; colocou-se, então, uma segunda camada de igual espessura na diagonal, apoiando-se na parede lingual e fotopolimerizou-se através desta parede; por fim uma terceira camada foi inserida para o preenchimento completo do preparo e este foi fotopolimerizado através da parede vestibular por 20 segundos.

Após os três grupos de dentes receberem seus respectivos materiais, os espécimes foram acondicionados em recipientes plásticos de filme fotográfico contendo água deionizada e colocados em uma Estufa de Culturar a $37^{\circ} \mathrm{C}$ por $24 \mathrm{~h}$. Decorrido este período, as restaurações receberam acabamento e polimento com a finalidade 
de se remover os excessos na parede cervical, uma vez que a perfeita adaptação da cunha reflexiva foi prejudicada devido à parede cervical estar localizada abaixo da junção cemento esmalte e, também, ao freqüente achatamento proximal, acarretando um pequeno escoamento de material pela região cervical. Este procedimento foi realizado fora do bloco de gesso, sendo que os excessos mais grosseiros foram removidos com brocas multilaminadass e pontas de acabamento Enhancet e o polimento foi realizado com discos Sof-Lex ${ }^{u}$. Os espécimes do grupo controle (restaurado com o material Vitremer), após o polimento, receberam uma camada de "Finishing Gloss" - produto presente no conjunto do material - com o auxílio de um aplicador "microbrush"v, sendo este fotopolimerizado por 20 segundos, seguindo as orientações do fabricante.

Depois de terminado o acabamento e polimento, os grupos tiveram suas raizes marcadas, com pequenos cortes horizontais realizados sob refrigeração a água com disco diamantadow flexível dupla face, em peça de mão, para facilitar a definição do material utilizado em cada face proximal. Para isso, definiu-se que as faces proximais restauradas com ARISTON pHc receberiam um corte horizontal,

s KG Sorensen Ind. Com. Ltda. Bauru, SP / Brasil

t Dentsply Indústria e Comércio Ltda. Petrópolis, RJ / Brasil

u 3M do Brasil Ltda. Sumaré, SP / Brasil / Lote 00079 Jul/99

v Microbrush Coporation / USA

w KG Sorensen Ind. Com. Ltda. Bauru, SP / Brasil 
as faces restauradas com o material P-60 receberiam dois cortes horizontais e as faces restauradas com o Vitremer não teriam marcas em suas raízes.

Realizado este procedimento, cada grupo foi subdividido, sendo metade de suas restaurações armazenadas em água deionizada a $37^{\circ} \mathrm{C}$, enquanto a outra metade do grupo recebia o processo de ciclagem térmica.

Este processo foi realizado em água destilada, nas temperaturas de $5^{\circ} \mathrm{C}( \pm 2)$ e $55^{\circ} \mathrm{C} \quad( \pm 2)$, totalizando quinhentos ciclos. Freqüentemente a temperatura foi checada através de termômetros de mercúrio de $0^{\circ} \mathrm{C}$ a $260^{\circ} \mathrm{C}$. O tempo de permanência dos espécimes em cada banho foi de 15 segundos.

Depois do término da termociclagem, todos os dentes receberam uma gota de adesivo instantâneo universal Super Bonderx sobre o ápice e foram selados com duas camadas de esmalte para unhas (Priscilay de secagem rápida), respeitando-se as restaurações e $1 \mathrm{~mm}$ ao redor delas. Imediatamente a seguir foram imersos em solução aquosa de fucsina básica a $0,5 \%^{z}$ por $24 \mathrm{~h}$ a $37^{\circ} \mathrm{C}$. Ao término deste período, os dentes foram lavados, abundantemente, em água corrente por $24 \mathrm{~h}$.

$x$ Loctite Brasil Ltda / validade: 05/2000

y Marka Rezende Ind. Cosméticos Ltda. / validade: 09/2000

$z$ Fornecido pelo departamento de Bioquímica da FOB - USP 
Para análise da microinfiltração, os dentes foram incluídos em resina acrílica autopolimerizável Resapol T-208a' em tubos de PVC $3 / 8$, previamente cortados a cada $3 \mathrm{~cm}$, fixados em uma lâmina de cera utilidade como base, onde foram obtidas as medidas apropriadas para serem adaptados na máquina de corte EXTEC Labcut 1010b' (Figura 8). Para a inclusão, a resina acrílica autopolimerizável foi manipulada e inserida, lentamente, no interior dos tubos, local onde o dente restaurado foi previamente posicionado com a face vestibular ou lingual da coroa dentária voltada para o fundo (em contato com a cera) de maneira que os cortes pudessem ser realizados no sentido mesio-distal e o mais perpendicular possivel ao fio da lâmina do disco de diamante.

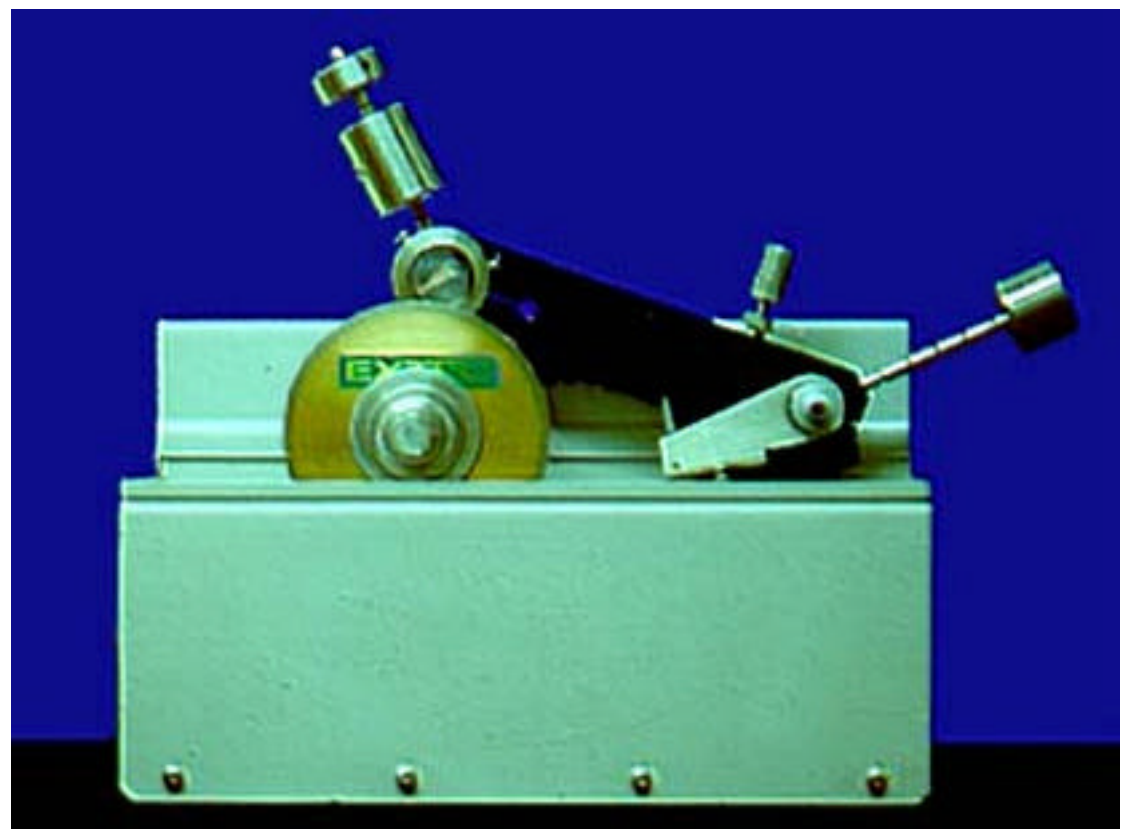

Figura 8: Máquina de corte com disco e dente posicionados para seccionamento

a' Redefibra Com. de Prod. para Fiberglass Ltda.

b' Excel, Technologies, Inc. Enfield, CT / EUA 
Para cada espécime foram obtidas 4 a 5 secções mésio-distais, com espessura aproximada de 0,8 a $1 \mathrm{~mm}$. Esta espessura era previamente determinada, com o auxílio de um dispositivo acoplado à máquina, descontando-se $0,3 \mathrm{~mm}$ correspondentes à espessura do disco de diamante.

Os cortes foram realizados em velocidade de 320rpm, sob refrigeração a água. Cada espécime seccionado foi lavado após o corte para remover resíduos provenientes do seccionamento e então, identificado em uma etiqueta com números, para que pudesse ser corretamente reconhecido durante a avaliação (Figura 9).

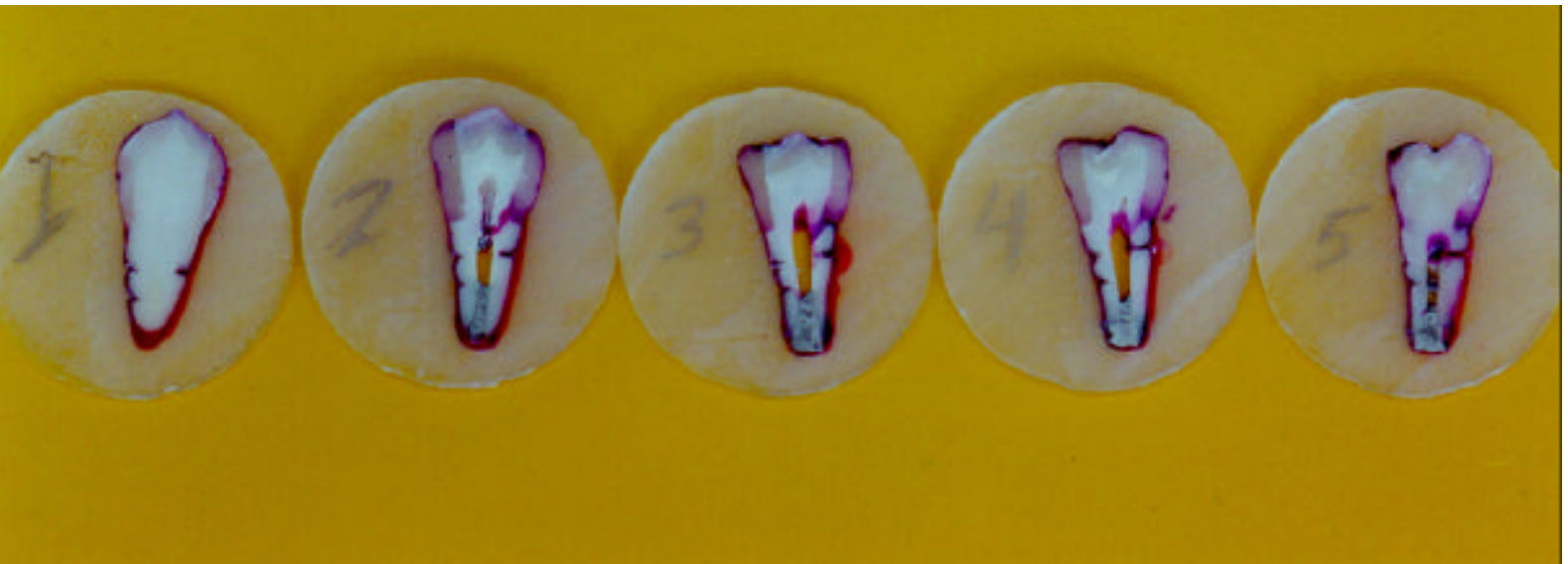

Figura 9: Esquema ilustrando aspecto das fatias obtidas dos espécimes

Cada corte identificado foi passado por um scannerc'. De cada segmento eram obtidas duas imagens; dessa forma, como nos dentes eram conseguidos, em média, quatro cortes; eram captadas oito faces

\footnotetext{
c' Modelo ScanJet 6100C, Hewlett Packard Co.
} 
a serem analisadas e assim sucessivamente.

Ao realizar-se a captura das imagens era posicionado, juntamente com os cortes, um paquímetro que futuramente serviria como calibragem da unidade de medida (Figura 10). No mesmo momento, já se realizava o ajuste padronizado de brilho e contraste da imagem captada pelo próprio "software" que acompanha o "scanner", de forma a evidenciar a área de interface denterestauração. Todas as imagens foram capturadas, empregando-se a mesma resolução do programa (600 x 600 pontos por polegada) e sempre na escala de $100 \%$.

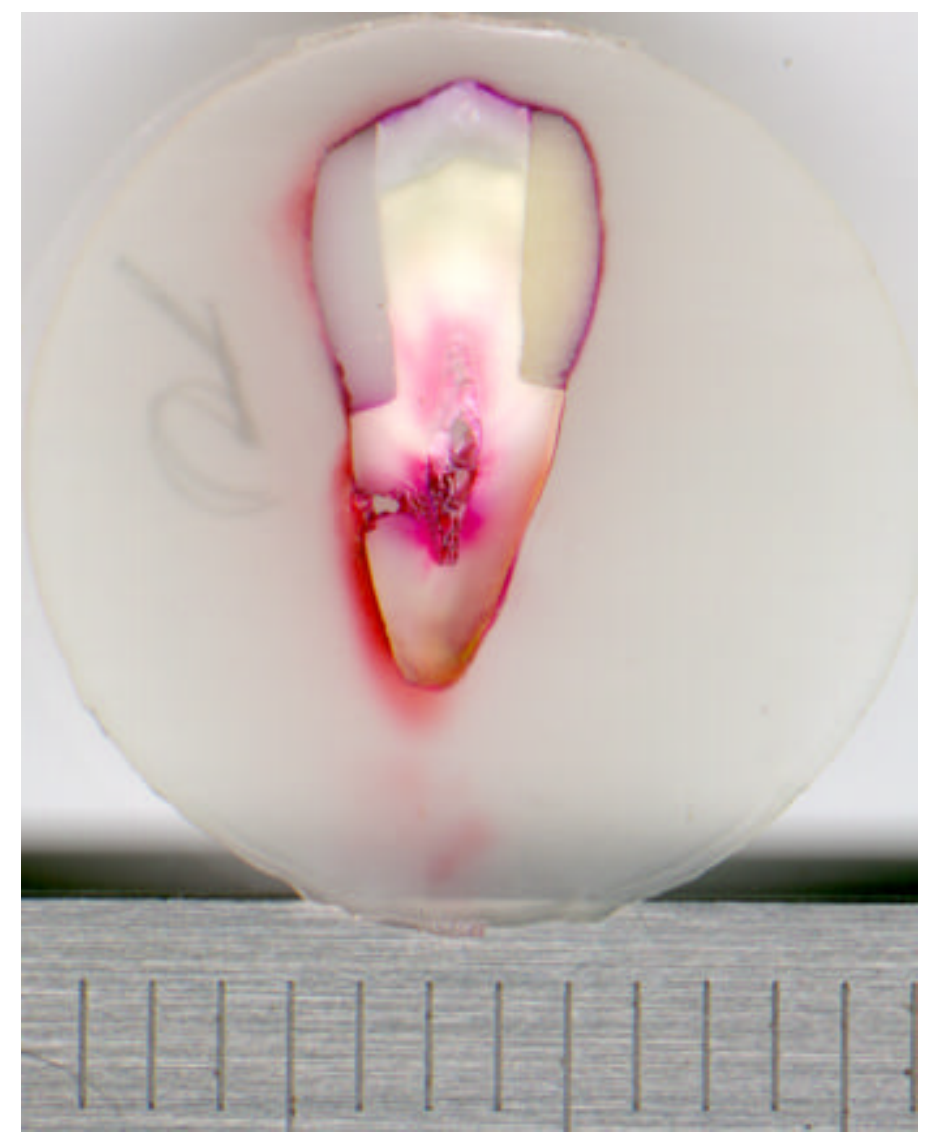

Figura 10: Exemplo da imagem capturada pelo scanner com paquímetro posicionado 
De posse das imagens, mediu-se a penetração do corante pela interface. Para tal, utilizou-se o programa de análise de imagem, desenvolvido pelo Departamento de Diagnóstico Dental da Universidade do Centro de Ciência da Saúde do Texas, denominado Imagetool. Como a unidade de medida desse programa é em pixels, inicialmente convertia-se essa unidade para milimetros, traçando-se uma reta entre dois pontos do paquímetro que equivalesse a $1 \mathrm{~mm}$. A distância entre esses dois pontos sempre era de 24 pixels. Todos os cortes obtidos de um mesmo dente foram mensurados, considerando-se para comparação entre os grupos, a média das infiltrações obtidas dos oito segmentos avaliados ou apenas aquele segmento que obteve maior extensão de penetração do corante.

Os dados foram analisados através do teste estatístico de análise de variância a 2 critérios (2-way ANOVA) juntamente com o teste de comparações múltiplas de Tukey em um nível de significância de 5\%. 
5 - Resultados 


\section{5 - RESULTADOS}

Para os dois métodos de avaliação foram realizadas 287 leituras para o cimento de ionômero de vidro modificado por resina Vitremer, 294 leituras para a resina composta "semicondensável" Ariston e 294 para a resina composta "condensável" P-60; sendo estas divididas pela realização ou não da termociclagem conforme a Tabela 1.

Tabela 1 - Número total de leituras realizadas nos 3 grupos de estudo, subdivididos em com e sem ciclagem térmica

\begin{tabular}{lc}
\hline $\begin{array}{r}\text { MATERIAL } \\
\text { ESTUDADO }\end{array}$ & $\begin{array}{c}\text { N. }{ }^{\circ} \mathrm{DE} \\
\text { LEITURAS }\end{array}$ \\
\hline Vitremer com & 143 \\
Vitremer sem & 144 \\
Ariston com & 149 \\
Ariston sem & 145 \\
P-60 com & 145 \\
P-60 sem & 149 \\
\hline \hline
\end{tabular}


Na tabela 2 observam-se os valores da média e desvio padrão obtidos dos três materiais testados, nas condições de com ou sem ciclagem térmica, através da utilização da média dos valores ou máximos valores observados para cada grupo.

Tabela 2 - Valores da média $(\overline{\mathrm{X}})$ e desvio padrão $(\mathrm{dp})$, da média das infiltrações ou máxima infiltração, obtidos dos três materiais testados, nas condições de com e sem ciclagem térmica, medidas em milímetros

\begin{tabular}{lccccc}
\hline \hline MATERIAL & CICLAGEM & \multicolumn{2}{c}{ MÉDIA } & \multicolumn{2}{c}{ MÁXIMA } \\
ESTUDADO & TÉRMICA & $\mathbf{x}$ & $\mathbf{d p}$ & $\mathbf{x}$ & $\mathbf{d p}$ \\
\hline Vitremer & $\mathbf{c o m}$ & 0,0455 & 0,0960 & 0,1120 & 0,2134 \\
Vitremer & sem & 0,0280 & 0,0504 & 0,1145 & 0,1729 \\
Ariston & com & 0,6440 & 0,3423 & 0,9330 & 0,4024 \\
Ariston & sem & 0,7165 & 0,4291 & 1,0260 & 0,4507 \\
P-60 & com & 0,5725 & 0,3369 & 0,8960 & 0,3408 \\
P-60 & sem & 0,3715 & 0,3322 & 0,6215 & 0,3829 \\
\hline \hline
\end{tabular}

Na figura 11 o gráfico mostra a semelhança de comportamento dos materiais estudados, quando estes são avaliados pelos máximos valores de infiltração ou pela média das infiltrações observadas, no 
presente estudo. Destaca-se apenas o deslocamento para valores maiores, quando se utilizou a média dos máximos valores de microinfiltração e uma diferença maior para o P-60 entre as condições de com ou sem termociclagem.

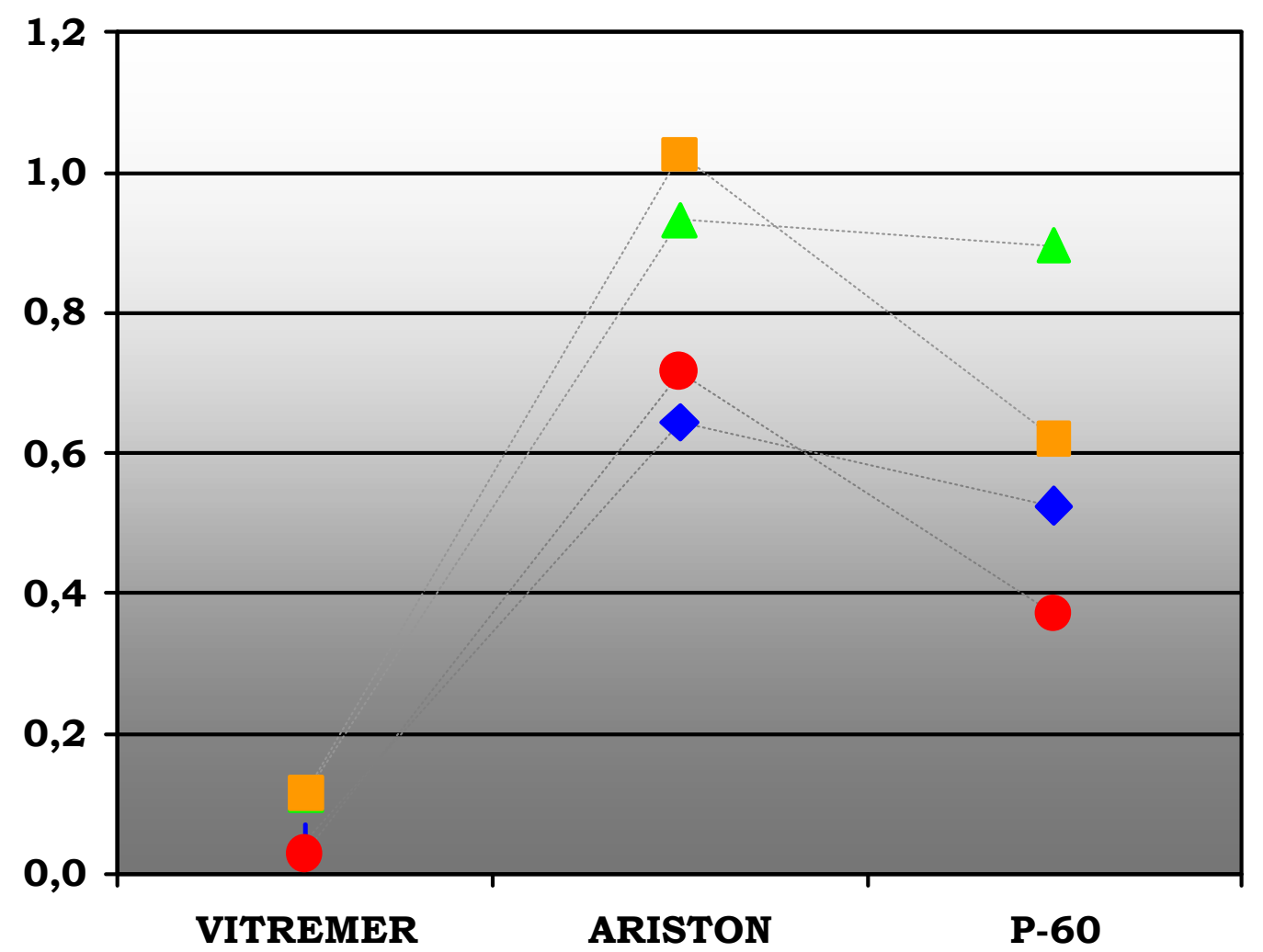

\section{Máximos valores com …ㅁ...-Máximos valores sem \\ Média de valores com $\quad$ Média de valores sem}

Figura 11 - Gráfico das médias das avaliações obtidas quando utilizados os máximos valores ou a média de valores da microinfiltração marginal dos três materiais testados nas condições de com ou sem ciclagem térmica 
Para selecionar o melhor teste estatístico a ser utilizado, optou-se pela realização do teste de normalidade e de independência dos grupos, os quais demonstraram em seus resultados que, principalmente, o grupo do Vitremer não possui distribuição normal. Entretanto, pelo fato da amostra ser grande $(\mathrm{N}=120)$, este desvio da normalidade de apenas alguns grupos, não afetam significantemente a análise de variância a 2 critérios (2-way ANOVA), que foi o teste estatístico selecionado ${ }^{71,81}$.

O teste estatístico foi primeiramente realizado de acordo com a tabela 3, utilizando-se a média dos valores de microinfiltração, onde se pode observar que houve diferença estatisticamente significante ao nível de $5 \%$ entre os materiais estudados, entretanto, os resultados demonstraram não existir interação significante e nem diferença estatisticamente significante em relação à termociclagem, possibilitando-se, juntar os grupos de estudo sem descriminar a realização ou não da ciclagem térmica, para responder quais médias podem ser consideradas diferentes entre si através da realização do teste de Tukey para comparações múltiplas entre os materiais. 
Tabela 3 - Parâmetros para o teste de Análise de variância a 2 critérios, utilizando-se a média dos valores de infiltração obtida para cada espécime

\begin{tabular}{lcccccc}
\hline \hline FONTE DE & g1 & QM & g1 & QM & F & p \\
VARIAÇÃO & EFEITO & EFEITO & ERRO & ERRO & & \\
\hline Material & $2^{*}$ & $4,3127^{*}$ & $114^{*}$ & $0,0895^{*}$ & $48,1846^{*}$ & $0,0000^{*}$ \\
Ciclagem & 1 & 0,0710 & 114 & 0,0895 & 0,7938 & 0,3748 \\
Interação & 2 & 0,0194 & 114 & 0,0895 & 2,1707 & 0,1188 \\
\hline \hline
\end{tabular}

* Significante a $5 \%$

O teste de Tukey (tabela 4) mostrou existir, entre os materiais, diferença estatística significante.

Tabela 4 - Teste de Tukey, utilizando-se a média dos valores, para comparações múltiplas entre os materiais

\begin{tabular}{lll} 
& \multicolumn{1}{c}{ MATERIAL } \\
I & \multicolumn{1}{c}{ ESTUDADO } & X \\
I & Vitremer & 0,0367 \\
I & P 60 & 0,0472 \\
& Ariston & 0,0680
\end{tabular}


Todavia, ao utilizar-se o valor máximo de microinfiltração, obtido para cada espécime (tabela 5), os resultados no teste ANOVA a 2 critérios demonstraram existir, além de diferença estatisticamente significante ao nível de $5 \%$ entre os materiais testados, também uma interação significante entre os grupos. Desse modo, para a realização do teste de Tukey (tabela 6) os grupos devem ser separados conforme a realização ou não da termociclagem.

TABELA 5 - Parâmetros para o teste de Análise de variância a 2 critérios, utilizando-se o valor máximo de infiltração obtido para cada espécime

\begin{tabular}{ccccccc}
\hline \hline FONTE DE & g1 & QM & gl & QM & F & p \\
VARIAÇÃO & EFEITO & EFEITO & ERRO & ERRO & & \\
\hline Material & $2^{*}$ & $8,1052^{*}$ & $114^{*}$ & $0,1172^{*}$ & $69,1479^{*}$ & $0,0000^{*}$ \\
Ciclagem & 1 & 0,1068 & 114 & 0,1172 & 0,9112 & 0,3418 \\
Interação & $2 *$ & $0,3666^{*}$ & $114^{*}$ & $0,1172^{*}$ & $3,1277^{*}$ & $0,0476^{*}$ \\
\hline \hline
\end{tabular}

${ }^{*}$ Significante a $5 \%$ 
Tabela 6 - Teste de Tukey, utilizando-se o máximo valor, para comparações múltiplas entre os materiais

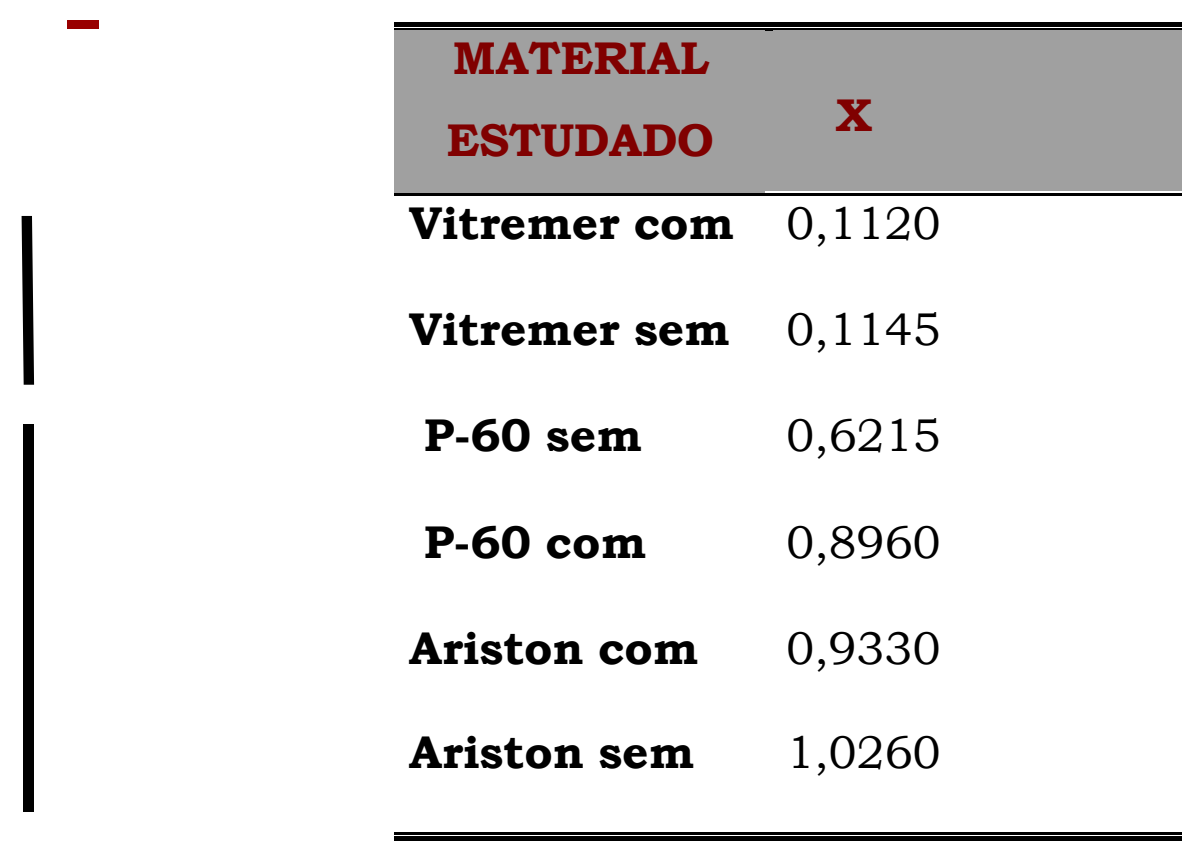

Grupos unidos por barra vertical não possuem diferença estatisticamente significante entre si.

As Figuras 12, 13, 14, 15, 16 e 17 representam aspectos do padrão da microinfiltração marginal da parede cervical dos diferentes grupos de estudo. 


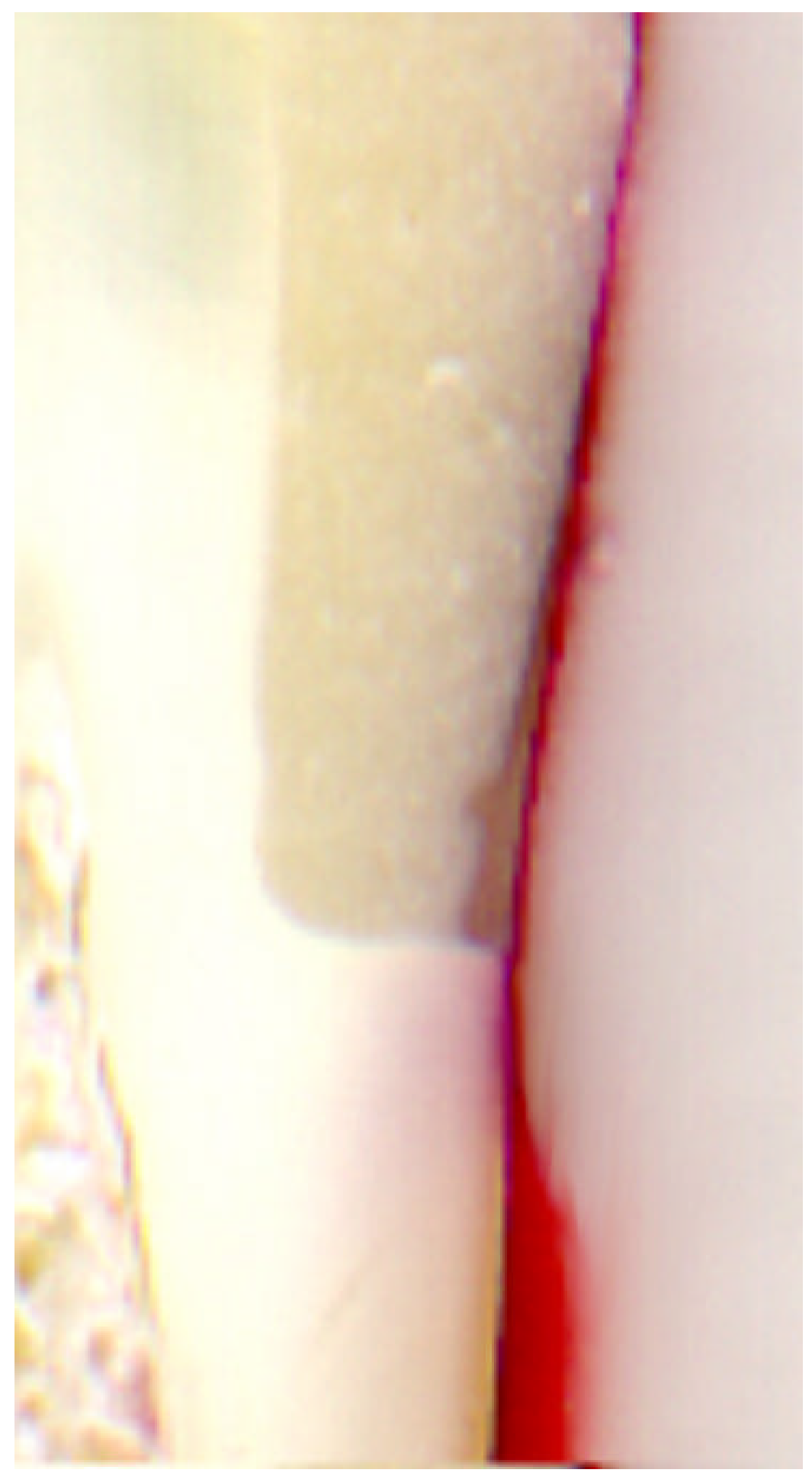

Figura 12: Aspecto do padrão da microinfiltração marginal da parede cervical apresentado pelo grupo I (Vitremer) com realização da termociclagem 


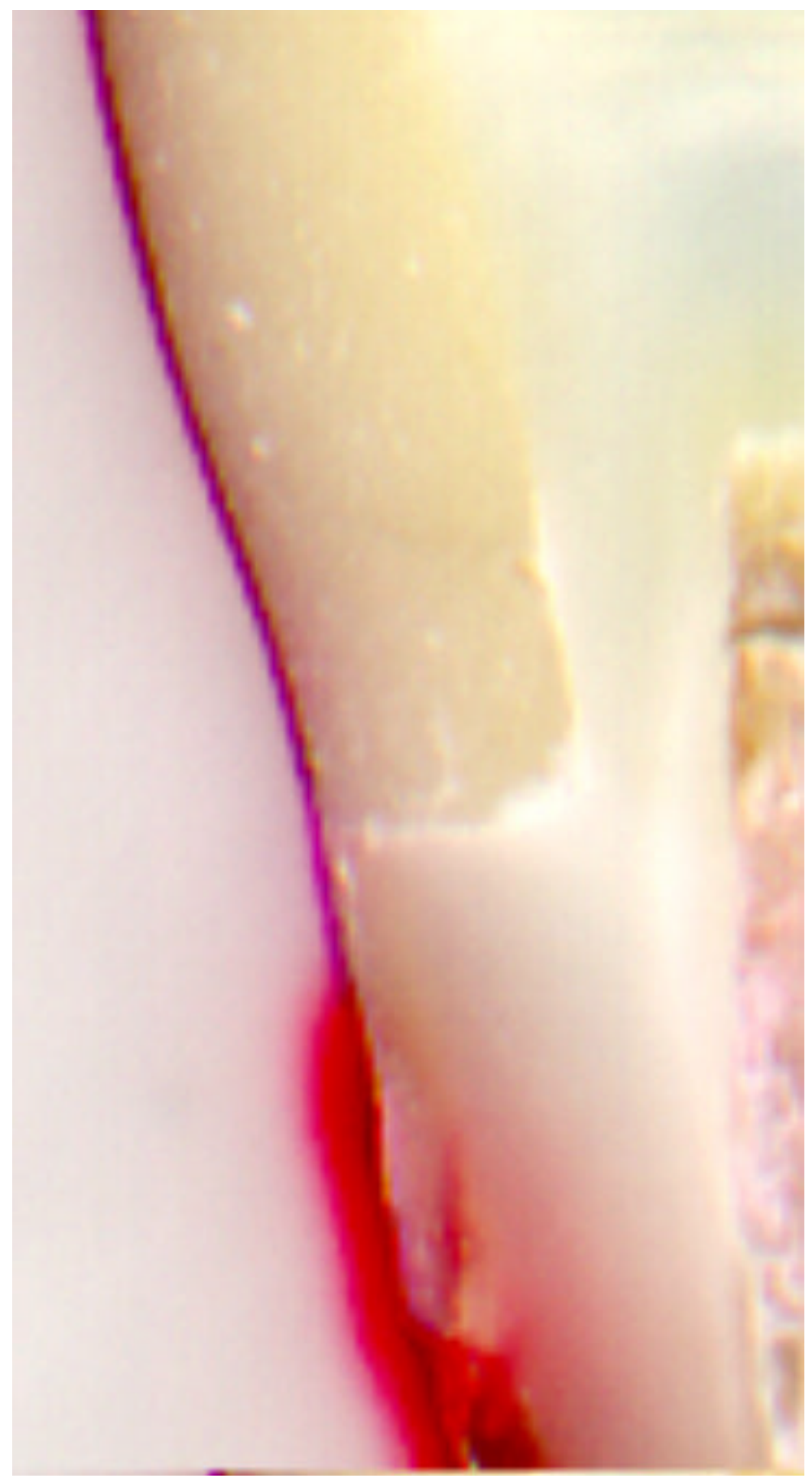

Figura 13: Aspecto do padrão da microinfiltração marginal da parede cervical apresentado pelo grupo I (Vitremer) sem realização da termociclagem 


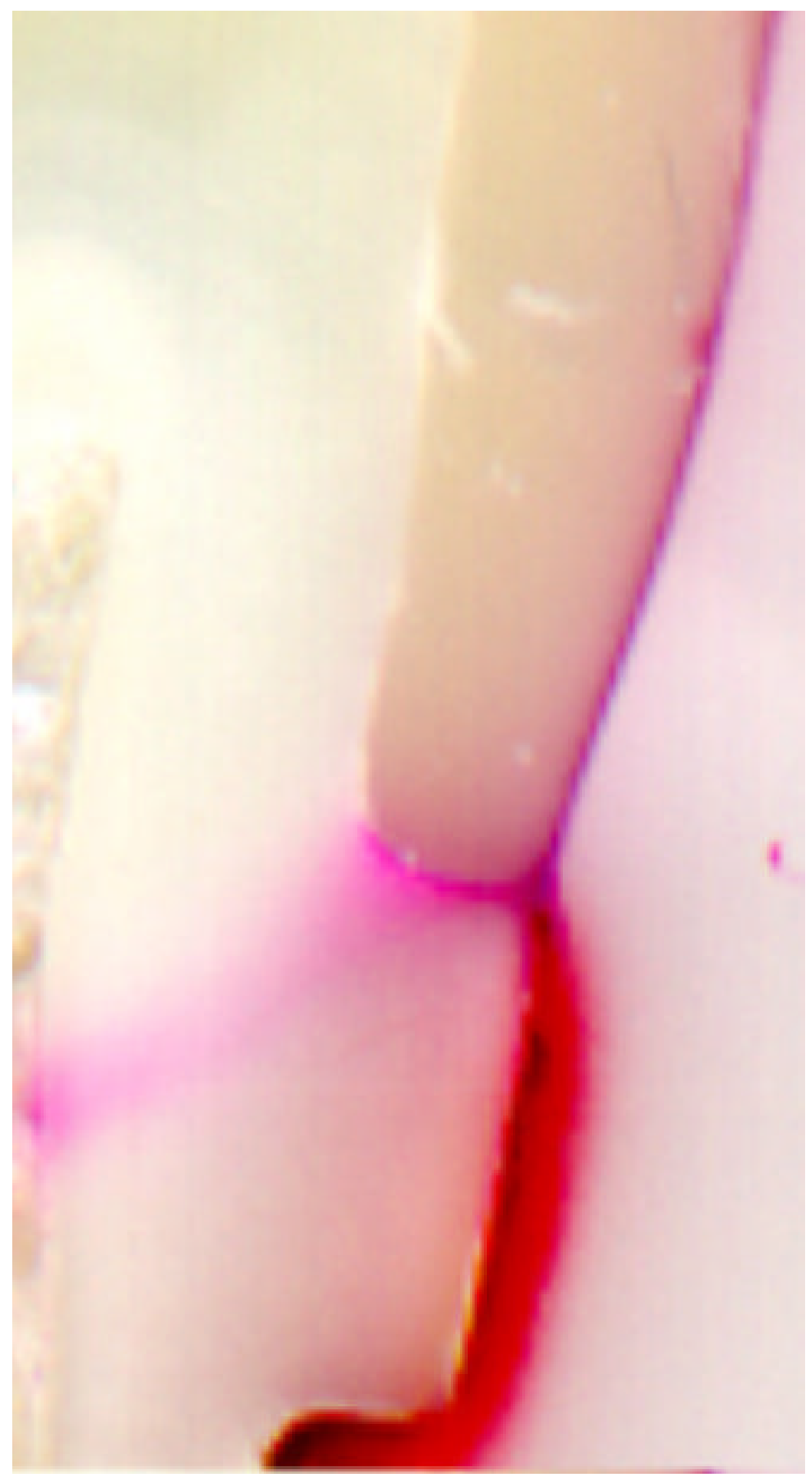

Figura 14: Aspecto do padrão da microinfiltração marginal da parede cervical apresentado pelo grupo III (P-60) com realização da termociclagem 


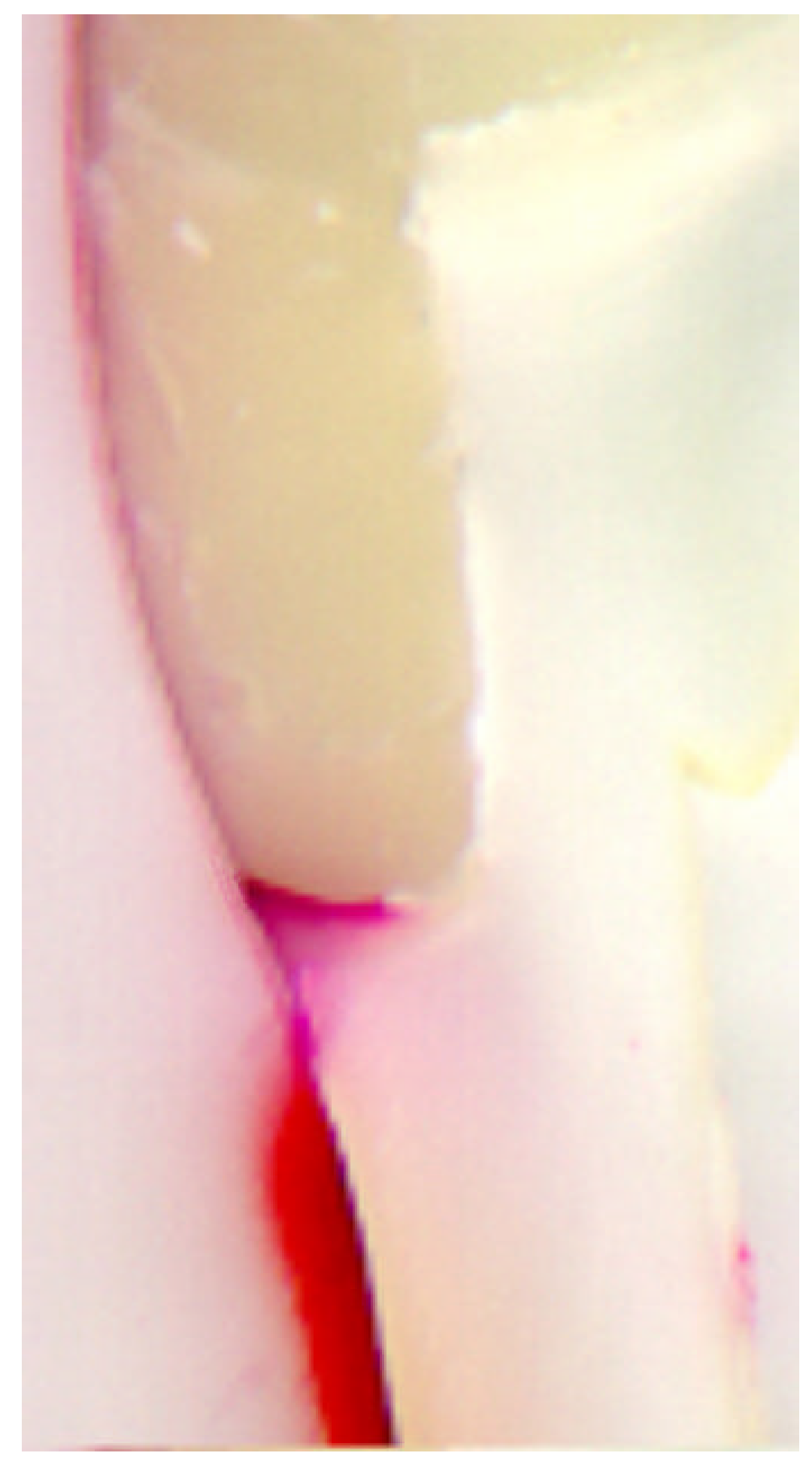

Figura 15: Aspecto do padrão da microinfiltração marginal da parede cervical apresentado pelo grupo III (P-60) sem realização da termociclagem 


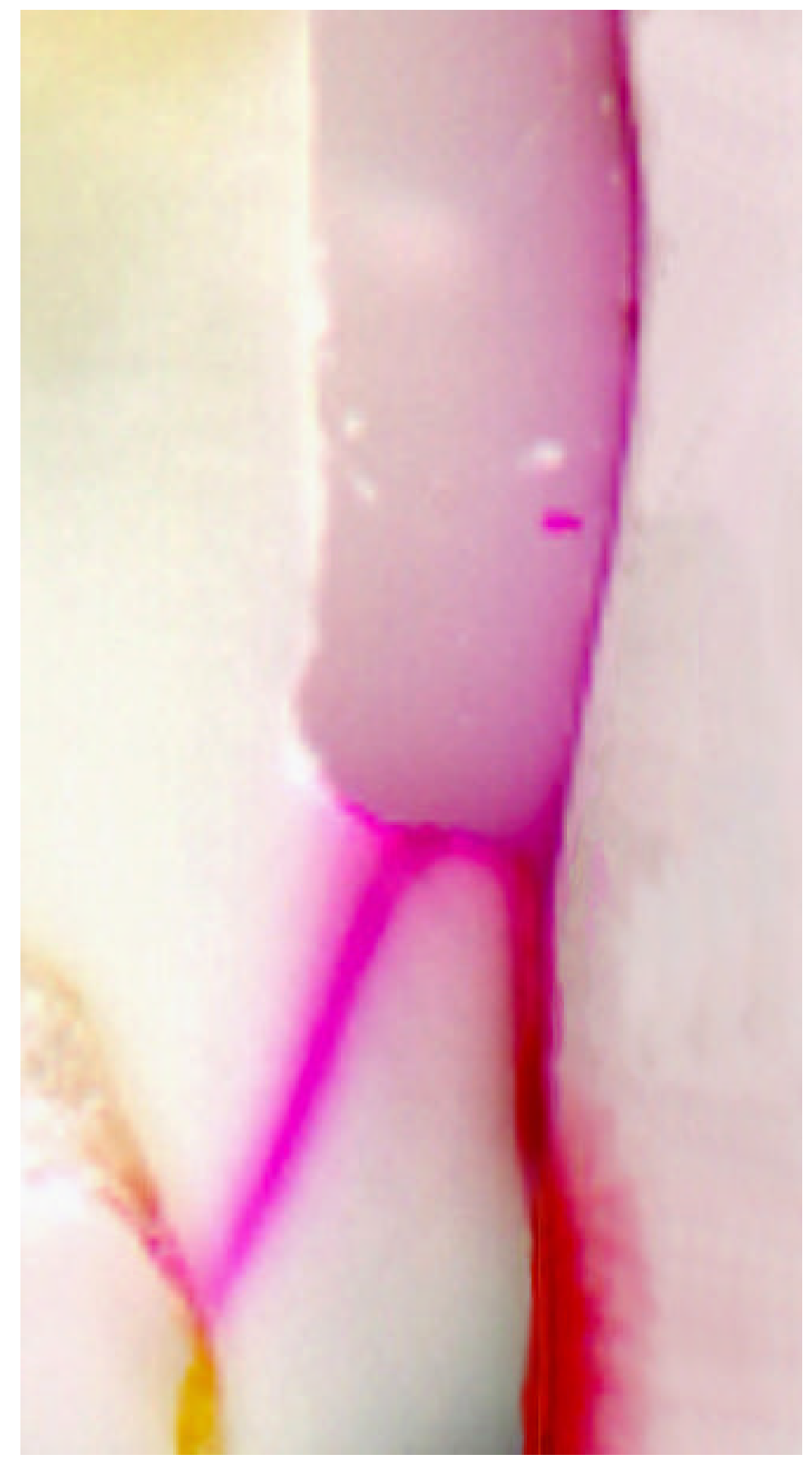

Figura 16: Aspecto do padrão da microinfiltração marginal da parede cervical apresentado pelo grupo II (Ariston) com realização da termociclagem 


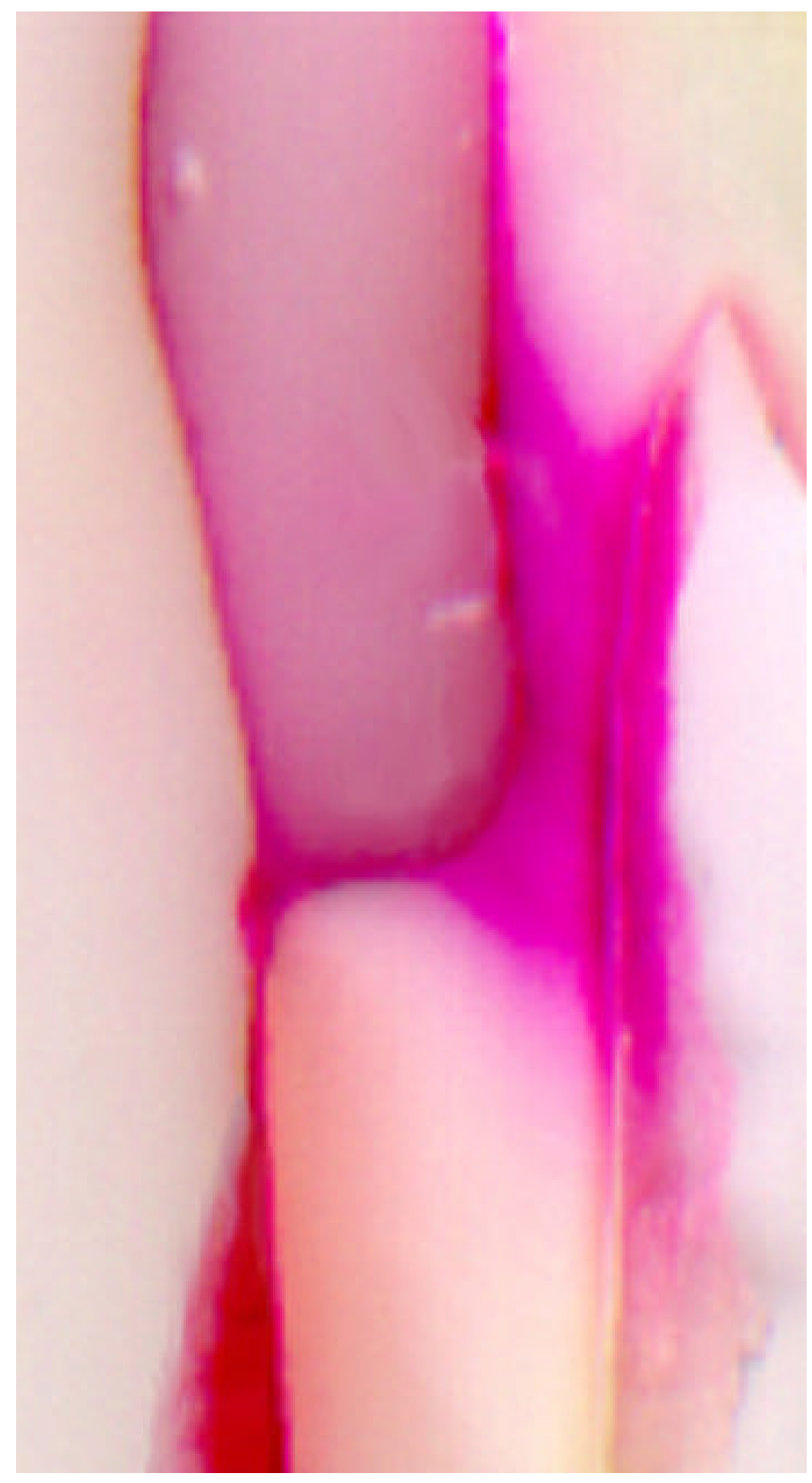

Figura 17: Aspecto do padrão da microinfiltração marginal da parede cervical apresentado pelo grupo II (Ariston) sem realização da termociclagem 
6 - Discussão 


\section{6 - DISCUSSÃO}

Com o sucesso da odontologia restauradora estética nos últimos anos e o aparecimento de diferentes materiais restauradores para dentes posteriores, torna-se importante avaliar a capacidade do selamento marginal dos novos materiais, buscando, se não eliminar completamente, ao menos minimizar a microinfiltração. Desse modo, muitas modificações foram propostas aos materiais e às técnicas restauradoras, na tentativa de solucionar este problema e aumentar a longevidade das restaurações.

Através da revisão de literatura pode-se observar que grande parte dos estudos sobre microinfiltração, que estão sendo realizados in vitro, não possuem um consenso de procedimentos e metodologias entre os pesquisadores, impossibilitando uma comparação eficaz entre eles $^{32}$.

Existem muitas formas de se avaliar a microinfiltração dos materiais. Essas técnicas segundo TAYLOR; LYNCH72 e ALANI; TOH ${ }^{1}$, incluem o uso de corantes orgânicos, testes bacterianos, condutividade elétrica ou térmica, traçadores químicos e radioativos, formação de cáries artificiais, entre outros. O uso de corantes é, sem duvida, a técnica mais freqüentemente utilizada $19,21,26,51,52,60,66,69,80$ e dentre eles, 
a fucsina básica a $0,5 \%$ consiste num dos corantes de maior utilização'13,17,27,49,57,74 por evidenciar bem a microinfiltração na interface dente/restauração através de um bom contraste e não pigmentar o dente durante o seccionamento com refrigeração a água 16. Embora os resultados obtidos não possam ser diretamente extrapolados para o dia-a-dia, pela incapacidade de tal estudo reproduzir com fidelidade as condições clínicas, eles são importantes porque fornecem diretrizes do comportamento desses materiais.

Neste estudo, foram utilizados 60 pré-molares, pela possibilidade de obtenção desses dentes jovens e hígidos (extraídos por indicação ortodôntica), divididos em 3 grupos com 20 dentes cada. Em cada dente foram realizadas restaurações nas faces mesiais e distais com a parede cervical situada abaixo da junção cemento-esmalte, local este de maior propensão à microinfiltração ${ }^{31,56,60,69}$.

A seleção dos materiais utilizados foi realizada entre os muitos lançamentos existentes no mercado atual com possivel uso na Odontopediatria. Optou-se por avaliar neste estudo a P-60 (Grupo III), uma das mais novas resinas "condensáveis" para dentes posteriores lançadas no mercado; a resina Ariston pHc (Grupo II) lançada com a promessa de liberar íons flúor, cálcio e hidroxila, mediante a ocorrência de uma queda no $\mathrm{pH}$ e o cimento de ionômero de vidro modificado por resina Vitremer (Grupo I), bastante utilizado nas clínicas de Odontopediatria. Devido ao recente lançamento no mercado 
e à escassez da literatura em trabalhos que avaliam a microinfiltração desses dois materiais, (Ariston pHc e P-60) os resultados desta pesquisa foram comparados em sua maioria com trabalhos em que foram utilizadas outras resinas compostas em dentes posteriores.

Os grupos foram subdivididos em com e sem termociclagem, com o intuito de avaliar sua efetividade nos materiais não metálicos como os cimentos de ionômero de vidro e as resinas compostas, devido à grande freqüência observada na literatura de estudos in vitro que utilizam estes testes ${ }^{13,16,17,19,22,23,27,38,40,51,57,64,66,74}$ com o objetivo de, submetendo os espécimes testados às temperaturas compativeis com as extremas observadas na cavidade bucal,1,77 avaliar a microinfiltração nesses materiais.

No presente trabalho, a termociclagem foi realizada em água deionizada, durante 500 ciclos, nas temperaturas de $5^{\circ} \mathrm{C}$ e $55^{\circ} \mathrm{C}$, com período de imersão de 15 segundos em cada banho. Apesar de haver autores como RETIEF59 que aconselham a realização da termociclagem em corante, optou-se pela realização da mesma em água com posterior imersão no corante o que está em conformidade com os trabalhos de CARRARA ${ }^{16}$, DAVIS et al.22, GWINNETT et al. ${ }^{38}$, PIN57 e SALLES64. O número de ciclos foi definido com base na revisão de literatura 16, 21, 27, $38,49,51,57,64,80$ onde o uso de 500 ciclos parece ser a quantidade mais freqüentemente utilizada. Os tempos de permanência, nas temperaturas extremas, encontrados na literatura variaram de 15 
segundos a 120 segundos $^{1}$; porém neste estudo optou-se por 15 segundos por ser considerado um tempo de relevância clínica na exposição a mudanças de temperatura, visto que, para ser tolerada, esta não permanece baixa ou elevada por períodos mais extensos ${ }^{59,} 77$.

Após a realização do teste de termociclagem e antes da imersão dos espécimes no corante, realizou-se em todo o dente, a aplicação de duas camadas de esmalte de unha, respeitando-se as restaurações e $1 \mathrm{~mm}$ ao redor delas, com o intuito de impedir a penetração do corante em áreas não desejadas. Este tipo de proteção, também utilizado por outros autores $16,21,26,27,38,49,57,61,64,74$ mostrou-se bastante eficaz também neste trabalho, não havendo nenhum caso de perda de espécimes por este motivo.

Para cada dente obteve-se uma média de 4 cortes no sentido mesio-distal, proporcionando até oito análises para cada um e portanto, 160 análises para cada subgrupo. Entretanto, na tabela 1 pode-se observar uma diferença numérica na quantidade de leituras realizadas para cada grupo, decorrente do diferente tamanho dos dentes cortados ou do descarte de fatias que não apresentavam condições de avaliação, devido à posição em que o corte se apresentava.

A técnica de seccionamento múltiplo obtendo-se diversas fatias, da forma como foi descrita, também foi utilizada por outros autores $^{21,26,27,52,74,77}$ e tem como objetivo permitir uma avaliação mais 
acurada do grau de microinfiltração, visto que, se fosse realizado somente um corte através do centro da restauração19,43 poder-se-ia estar perdendo informações 38,41 , o que pôde ser observado neste estudo, onde o padrão de penetração do corante teve grande variação em um mesmo dente ou até na mesma fatia, reforçando assim a necessidade da avaliação ser realizada em vários cortes e de ambos os lados das fatias.

$\mathrm{Na}$ avaliação final dos grupos (tabela 1) obteve-se 287 leituras para o Vitremer (143 com e 144 sem termociclagem); 294 leituras para Ariston pHc (149 com e 145 sem termociclagem) e 294 leituras para a P-60 (145 com e 149 sem termociclagem).

Na tabela 2 é possível observar os valores da média e desvio padrão, obtidos dos três materiais testados, através das imagens dos cortes que, após passarem por um scanner, foram avaliadas com a utilização de um programa de computador denominado "Imagetools". Todavia, apesar de existirem na literatura dados que evidenciem a consideração apenas da máxima infiltração ocorrida em todas as fatias, como a forma mais sensivel de se detectar a efetividade dos sistemas restauradores, no controle da microinfiltração ${ }^{16,23,52}$ pôde-se observar que alguns trabalhos ainda utilizam a média dessas avaliações $26,57,64,80$. Esse fato incentivou a inclusão, nas proposições, da avaliação dos dois métodos de análise da penetração do corante para a avaliação da microinfiltração marginal in vitro. Sendo assim, 
nesta tabela pode-se verificar valores em milímetros, da média $\overline{(\mathrm{X})}$ e desvio padrão (dp), quando foi utilizada a média das infiltrações ou a máxima infiltração registrada em cada corpo de prova.

Na figura 11 o gráfico permite visualizar a semelhança de comportamento entre os materiais quando foram avaliados pela máxima infiltração ou pela média das infiltrações obtidas para cada espécime, destacando-se apenas o deslocamento para valores maiores quando a máxima infiltração foi utilizada.

Como pode-se observar na tabela 2, o Vitremer, quando foi avaliado através dos valores médios de infiltração e sofreu termociclagem, obteve média de $0,0455 \mathrm{~mm}$ o que foi semelhante aos resultados obtidos quando não sofreu o teste de termociclagem $(0,0280 \mathrm{~mm})$. Estes valores tornaram-se ainda mais próximos quando as amostras foram avaliadas através da máxima infiltração, correspondendo a $0,1120 \mathrm{~mm}$ para o Vitremer com termociclagem e 0,1145mm para o sem termociclagem. Essa concentração do Vitremer no valor ZERO, portanto uma maior eficácia em reduzir a microinfiltração, pode ser atribuída a sua característica de aderir quimicamente à estrutura dentária e à semelhança entre o seu coeficiente de expansão térmica e o coeficiente da estrutura dentária, registrando assim os valores mais baixos de microinfiltração do presente trabalho. Esses dados estão de acordo com os trabalhos de CARRARA ${ }^{16}$, MILLER et al.52, OLIVEIRA ${ }^{54}$, PIN57 e SALLES ${ }^{64}$ que 
consideraram melhores os resultados com a utilização do cimento de ionômero de vidro modificado por resina Vitremer; e também com autores como DARBYSHIRE; MESSER; DOUGLAS ${ }^{21}$, HEMBREE JÚNIOR40, SCHWARTZ; ANDERSON; PELLEU JÚNIOR66, PATRI56, MATHIS et al. ${ }^{51}$ e RETIEF; Mc CAGHREN; RUSSEL 60 que verificaram melhores resultados com o uso do cimento de ionômero de vidro, embora utilizando metodologias e materiais diferentes. Entretanto, os resultados deste trabalho estão em desacordo com VIEIRA et al. ${ }^{74}$ que considerou não haver diferença na microinfiltração marginal quando comparou o uso do Vitremer, Dyract ou Compoglass e também com CARRARA ${ }^{17}$ que considerou semelhante o desempenho do Vitremer, Compoglass e Z-100, apesar dos materiais e metodologias serem diferentes.

Na tabela 2 pode-se constatar, ainda, que apesar dos valores de microinfiltração serem inferiores ao material Ariston pHc, a resina composta P-60 apresentou uma maior alteração em relação à utilização ou não do teste de ciclagem térmica. Foram obtidos para a P-60 valores de $0,5725 \mathrm{~mm}$ e $0,3715 \mathrm{~mm}$ para com e sem termociclagem, respectivamente, quando a média das infiltrações foi analisada; e, quando a análise foi realizada através da máxima infiltração, os valores foram de $0,8960 \mathrm{~mm}$ para com e $0,6215 \mathrm{~mm}$ para sem o teste, destacando-se, assim, o aumento da microinfiltração quando do uso da termociclagem, embora não apresentando diferença 
estatisticamente significante (Tabela 3 e 5). Estes dados confirmam os descritos na literatura por RIGSBY et al.62 e ROSSOMANDO; WENDT JUNIOR ${ }^{63}$, que observaram não haver influência estatisticamente significante entre o uso ou não da termociclagem para as resinas compostas. Na figura 11, é possivel visualizar que ocorreu uma diferença de comportamento desse material (P-60) em relação aos demais testados, sendo observado mais facilmente quando esse foi avaliado pelos valores de máxima infiltração.

Já o material Ariston pHc, ao contrário da resina composta P-60 (Tabela 2), talvez pelas suas propriedades, obteve um deslocamento intermediário, onde o teste de termociclagem influenciou positivamente sua microinfiltração. Porém, apresentou valores de microinfiltração relativamente mais altos do que os demais materiais testados. Quando foi utilizada a média das medidas de microinfiltração, os valores foram de $0,6440 \mathrm{~mm}$ e $0,7165 \mathrm{~mm}$ para com e sem termociclagem, respectivamente, e quando a máxima infiltração foi avaliada, obteve-se valores de $0,9330 \mathrm{~mm}$ para com e $1,0260 \mathrm{~mm}$ para sem termociclagem. Esses dados poderiam ser justificados pelo fato do Ariston pHc apresentar uma contração de polimerização semelhante à das novas resinas compostas $(2,2 \%)^{14}$, porém utilizando apenas um "liner" para o selamento dentinário o que produziria fendas marginais. Entretanto, FONTANA et al. ${ }^{29}$ e SCHIFFNER ${ }^{65}$, após realizarem estudos sobre a eficácia desse material na prevenção de cáries secundárias, são 
unânimes em afirmar que o Ariston $\mathrm{pHc}$ demonstrou o melhor desempenho em cavidades com fendas marginais, sugerindo que a presença destas fendas ressalta seu efeito protetor, por produzir um ambiente desfavorável para o desenvolvimento do S. mutans, através das trocas iônicas preconizadas comercialmente para o material. Essas trocas iônicas (liberação de $\mathrm{Ca}^{++}, \mathrm{F}^{-}$e $\mathrm{OH}^{-}$) também são ressaltadas por outros autores 4,35,58,76. Ainda, KIELBASSA; MÜLLER; GARCIAGODOY ${ }^{46}$ realizaram um trabalho in situ onde compararam a liberação de flúor na prevenção à cárie dentária entre a resina composta Ariston pHc, o compômero Dyract e os cimentos de ionômero de vidro, Vitremer e Ketac-Molar, concluindo que apenas o Ariston pHc apresentou uma redução significante da mesma. Os autores sugeriram que os materiais restauradores que tentam prevenir a cárie secundária devam ter adição de ambos os íons, flúor e hidroxila.

Também, TRUMMLER; MÜLLER; WEISS,73 (dentes decíduos), BARANSKA-GACHOWSKA; BORKOWSKI; ZIAJA6 e CARE et al.15. (dentes permanentes), em trabalhos clínicos de um ano, utilizando critérios de avaliação como: sensibilidade pós-operatória; textura de superficie; descoloração; presença de cárie secundária; formação de fendas; desgaste oclusal; trincas e fraturas consideraram o material satisfatório sendo, ainda, ressaltado por GOMES; CAVINA; GOMES 35 que apesar da cor branco-opaco característica do material, o grau de satisfação do paciente é bom, principalmente devido ao efeito 
camaleônico da região posterior, onde o brilho dos materiais e da saliva pela transmissão de luz produz um mimetismo, mascarando as diferenças de cor a uma distância de conversação.

O teste estatístico de análise de variância a 2 critérios (2-way ANOVA) foi primeiramente realizado, conforme tabela 3, utilizando-se a média dos valores de microinfiltração. Nesta tabela pode-se observar a existência de uma diferença estatisticamente significante ao nível de $5 \%$ entre os materiais estudados, todavia os resultados demonstraram não existir interação significante $(p=0,11)$ e nem diferença estatisticamente significante em relação à utilização ou não do teste de termociclagem $(p=0,37)$.

A partir desses resultados, a utilização do teste de Tukey para comparações múltiplas (Tabela 4) foi realizada para responder quais médias podem ser consideradas diferentes entre os materiais. Por não existir uma interação significante, optou-se em juntar os grupos de estudo sem discriminar a realização ou não do teste de ciclagem térmica. Esse teste demonstrou ser, nas condições deste estudo, o Vitremer o material de maior capacidade para diminuir a microinfiltração abaixo da junção cemento-esmalte, seguido pela resina P-60 e em último lugar, com valores maiores de microinfiltração, a resina Ariston pHc.

Neste estudo, os resultados obtidos demonstraram uma diferença estatisticamente significante entre a resina "condensável" P-60 e a 
resina "semicondensável" Ariston pHc, o que esta em desacordo com BRAUN et al. ${ }^{8}$ que, em um estudo clínico de seis meses, verificaram não existir diferença estatisticamente significante entre o selamento marginal da resina composta "condensável" (Solitaire) e a resina composta "semicondensável" (Ariston pHc), justificando suas conclusões com a ressalva de que estes resultados foram obtidos devido à baixa resistência ao desgaste da resina Solitaire, enquanto que para o material Ariston foi devido sua baixa adesividade (formação de fendas), apesar das metodologias serem diferentes.

Todavia, ao utilizar-se o valor máximo de microinfiltração obtido para cada espécime (tabela 5), os resultados do teste de análise de variância a dois critérios (2-way ANOVA) demonstraram existir, além da diferença estatisticamente significante em nível de $5 \%$ entre os materiais testados, também uma interação significante entre os grupos, o que em relação à microinfiltração, demonstra ter o teste de termociclagem influenciado de maneira diferente os materiais testados, embora sem significância estatística. Desse modo, para a realização do teste de Tukey (tabela 6) os grupos foram separados conforme a utilização da termociclagem. Mesmo assim, é possível observar, nesta tabela, que o Vitremer foi considerado, entre os materiais avaliados, o que menos permitiu a penetração do corante, independente da utilização ou não do teste. Entretanto, ao considerar-se as resinas P-60 e Ariston pHc, verifica-se uma interação, principalmente quando 
sofreram o processo de termociclagem, o que é possivel observar, nesta tabela, onde os grupos unidos por barra vertical não possuem diferença estatisticamente significante entre si.

Os resultados, obtidos nesta pesquisa, estão de acordo com DÉJOU; SINDRES; CAMPS ${ }^{23}$, que afirmaram ser o parâmetro estatístico de máxima infiltração a medida comparativa mais adequada para as condições clínicas, pois mesmo utilizando-se o critério estatístico em nível de significância de 5\%, ao utilizar-se este método foi possível observar a interação entre os materiais, apesar de pequena.

Como dito anteriormente, pode-se considerar através da observação das tabelas 3 e 5 que o teste de ciclagem térmica para materiais como as resinas compostas ou os cimentos de ionômero de vidro não teve diferença estatisticamente significante na avaliação dos materiais.

Os resultados deste trabalho demonstraram que nenhum dos materiais estudados foi capaz de impedir totalmente a microinfiltração marginal, embora demonstrando uma diferença estatisticamente significante entre os mesmos, onde o cimento de ionômero de vidro modificado por resina Vitremer apresentou menor nivel de microinfiltração, seguido pelas resinas compostas P-60 e Ariston pHc, que apesar de demonstrarem uma microinfiltração maior em relação ao Vitremer, foram semelhantes entre si. Em relação ao uso dos testes 
de termociclagem, em estudos in vitro sobre microinfiltração, observouse que apesar de influenciar de maneira diferente os materiais, tal teste não apresentou significância estatística. Quanto aos métodos de avaliação da microinfiltração, o que utiliza a máxima infiltração parece ter uma maior validade clínica por melhor detectar a extensão da microinfiltração.

Além disso, acredita-se que o material Ariston pHc, apesar dos resultados apresentados, possa ter alguma importância para a clínica odontopediátrica, pois, embora não tenha selado completamente a interface dente restauração, eliminando a microinfiltração, relatos da literatura29,46,65 comprovam propriedades anticariogênicas de liberação de $\mathrm{Ca}^{++}, \mathrm{F}^{-}$e $\mathrm{OH}^{-}$, que segundo os mesmos previnem ou retardam o desenvolvimento de cáries secundárias, conservando um ambiente bucal satisfatório para as crianças. Desse modo, há necessidade de maiores comprovações laboratoriais que confirmem a efetividade desse material tanto em relação à microinfiltração marginal quanto à liberação de íons que previnam à cárie secundária. Ressaltando-se ainda, a necessidade de estudos clínicos, principalmente em dentes decíduos, para verificar o desempenho do mesmo em cavidades classe II. 


\section{7 - Conclusão}




\section{7- CONCLUSÃO}

De acordo com os resultados obtidos neste estudo e a análise estatística aplicada aos mesmos, pode-se concluir que:

Todos os grupos testados apresentaram microinfiltração marginal, sendo que o cimento de ionômero de vidro modificado por resina Vitremer (grupo I) apresentou resultados sempre melhores, vindos a seguir a resina composta "condensável" P-60 (grupo III) e por último a resina composta "semicondensável" Ariston pHc (grupo II);

$\checkmark$ Não houve diferença estatisticamente significante no uso da ciclagem térmica, quando se utilizou o cimento de ionômero de vidro modificado por resina Vitremer (grupo I), a resina composta "semicondensável" Ariston pHc (grupo II) ou a resina composta “condensável” P-60 (grupo III); 
Quando o método de análise de penetração do corante foi a média dos valores de microinfiltração marginal, houve diferença estatisticamente significante entre os materiais utilizados; entretanto, essa diferença não foi verificada em relação ao uso da ciclagem térmica;

$\checkmark$ Quando o método de análise de penetração do corante foi o valor máximo de microinfiltração obtido para cada espécime, houve diferença estatisticamente significante entre os materiais utilizados, ocorrendo uma interação entre os materiais e a termociclagem ao nível de significância de $5 \%$. 


\section{Referências Bibliográficas}




\section{REFERÊNCIAS BIBLIOGRÁFICAS*}

1 - ALANI, A.H.; TOH, C.G. Detection of microleakage around dental restorations: a review. Oper. Dent., v.22, n.4, p.173-85, July/Aug. 1997.

2 - AMERICAN DENTAL ASSOCIATION. Concil on Dental Materials, Instruments and Equipment. Obstacles to the development of a standard for posterior composite resins. J. Amer. dent. Ass., v.118, n.5, p.649-51, 1989.

3 - ANTONUCCI, J.M.; McKINNEY, J.E.; STANSBURY, J.W. Resin modified glass ionomer dental cement. US. Patent. 160856, 1988 apud SHIDU, S.K.; WATSON, T.F. ${ }^{68}$

4 - ARISTONTM pHc. Research and Development Scientific Service: Scientific Documentation. s.1., Ivoclar North America Inc., 1998. no documento "Orientações básicas para apresentação de dissertações e teses na FOBUSP“, publicado pelo Serviço de Biblioteca e Documentação da Faculdade de Odontologia de Bauru - Universidade de São Paulo, 1991. 
5 - ASMUSSEN, E. The effect of temperature changes on adaptative of resin fillings. Acta odont. scand., v.32, n.5, p.291-7, June 1974.

6 - BARANSKA-GACHOWSKA, M.; BORKOWSKI, L.; ZIAJA, M. Clinical evaluation of Ariston pHc restorations: 1-year results. Amer. J. Dent., v. 12, p.S19-20, Nov. 1999. Special Issue.

7 - BHOOLABHAI, S; GIACHETTI, L. Indicaciones clínicas y protocolo de um material para posteriores de color dental. Signature Int., v.3, n.3, p.1-3, Mar. 1998.

8 - BRAUN A.R. et al. Margin analysis of two differents resin composite systems after six months. J. dent. Res., v.79, p.186, 2000. Special issue Abstract n.339 . / Apresentado no 78th General Session of the International Association for Dental Research, April 5-8, Washington, DC, 2000/

9 - BRISO, A.L.F. et al. Avaliação da infiltração marginal em restaurações cervicais com cimento de ionômero de vidro fotopolimerizável: efeitos de tratamentos superficiais do esmalte e dentina. Rev. bras. Odont., v.55, n.3, p.153-9, maio/jun. 1998. 
10 - BULlARD, R.H.; LEINFELDER, K.F.; RUSSELL, C.M. Effect of coefficient of thermal expansion on microleakage. J. Amer. dent. Ass., v.116, n.7, p.871-4, June 1988.

11 - BUONOCORE, M. G. A simple method of increasing the adesion of acrylic filling materials to enamel surfaces. J. dent. Res., v.34, p. 849-53. 1955.

12 - BUSATO, A.L.S. et al. Restaurações diretas em resinas compostas para dentes posteriores : cursos antagônicos. In: FELLER, C.; GORAB, R. Atualização na clínica Odontológica. São Paulo, Artes Médicas, 2000. v.2, cap.1, p.3-27.

13 - CARDOSO, M.; VIEIRA, L.C.C. Infiltração Marginal em cavidades classe II MOD em pré-molares. Rev. Ass. paul. cirurg. Dent, v.52, n.1, p.65-8, jan./fev. 1998.

14 - CARDOSO, P.E.C.; MALLMANN, A. Resinas compostas condensáveis: uma nova opção restauradora. Guia dent. Gaúcho, v.6, n.2, p.26-30, maio 1999. 
15 - CARE, R. et al. Efficacy of a new caries-inhibitory restorative material and amalgam as control in 12-13 year-old Latvian adolescents with high caries prevalence: 1-year results. Amer. J. Dent., v. 12, p.S17-8, Nov. 1999. Special Issue.

16 - CARRARA, C.E. Avaliação da infiltração marginal de dois cimentos de ionômero de vidro híbridos restauradores. Bauru, 1995. 74p. Dissertação (Mestrado) - Faculdade de Odontologia de Bauru, Universidade de São Paulo.

17 - CARRARA, C.E. Avaliação da infiltração marginal e resistência ao cisalhamento de materiais restauradores adesivos em dentes deciduos. Bauru, 1999. 114p. Tese (Doutorado) Faculdade de Odontologia de Bauru, Universidade de São Paulo.

18 - CARVALHO, R.M. Ionômero de vidro. Maxi-Odonto: dentística, v.5, n.5, p.1-42, set./out. 1995

19 - CRIM, G.A.; CHAPMAN, K.W. Reducing microleakage in class II restorations: an in vitro study. Quintessence Int., v.25, n.11, p.781-5, Nov. 1994. 
20 - CROLL, T. P.; KILLIAN, C. M. Glass ionomer resin retorations of primary molars with adjacent class II carious lesions. Quintessence Int., v.24, n.10, p.723-7, Oct. 1993.

21 - DARBYSHIRE, P.A.; MESSER, L.B.; DOUGLAS, W.H. Microleakage in class II composite restorations bonded to dentin using thermal and load cycling. J. dent. Res., v.67, n.3, p.585-7, May 1988.

22 - DAVIS, E.L. et al. Shear strength and microleakage of light-cured glass ionomer. Amer. J. Dent., v.6, n.3, p.127-9, June 1993.

23 - DÉJOU, J.; SINDRES, V.; CAMPS, J. Influence of criteria on the results in vitro evaluation of microleakage. Dent. Mat., v.12, n.6, p.342-9. Nov. 1996.

24 - DEMARCO, F. F. et al. Avaliação da infiltração em cavidades classe II determinadas em cemento. In: ENCONTRO DO GRUPO BRASILEIRO DOS PROFESSORES DE DENTÍSTICA, 13, Recife, 1999. Anais. Recife, GBPD, 1999. p.86. / Resumo n.74/ p.86. 
25 - DIETSCHI, D. et al. Influence of the restorative technique and new adhesives on the dentin marginal seal and adaptation of resin composite class II restorations: a in vitro evaluation. Oper. Dent., v.26, n.10, p.717-27, Oct. 1995.

26 - DOERR, C.L.; HILTON, T.J.; HERMESCH, C.B. Effect of thermocycling on the microleakage of conventional and resinmodified glass ionomers. Amer. J. Dent., v.9, n.1, p.19-21, Feb. 1996.

27 - DOMINGUES, L.A. et al. The effect of restorative technique on marginal leakage of resin composite class II restoration $\mathbf{J}$. dent. Res., v.79, p.536, 2000. Special issue Abstract n.3137. / Apresentado no 78th General Session of the International Association for Dental Research, April 5-8, Washington, DC, $2000 /$

28 - FILTEK ${ }^{\mathrm{TM}}$ P-60. Restaurador para dentes posteriores: perfil técnico do produto. s.1., 3M Dental Products Laboratory, 1999. 
29 - FONTANA, M. et al. In vitro evaluation of a "smart" dental material for its efficacy in preventing secondary caries using a microbial artificial mouth model. Amer. J. Dent., v.12, p.S89, Nov. 1999. Special Issue.

30 - FUSAYAMA, T. New concepts in operative dentistry : differentiating two layers of carious dentin and using and adhesive resin. Chicago, Quintessence. 1980. 180 p.

31 - FUTATSUKI, M.; NAKATA, M. In vitro marginal leakage of class II composite resin restorations by thermal cycling. J. clin. pediat. Dent., v.18, n.3, p.191-6, June 1994.

32 - GALE, M.S.; DARVELL, B.W. Thermal cycling procedures for laboratory testing of dental restorations. J. Dent., v.27, n.2, p.89-99, Feb. 1999.

33 - GARCÍA-GODOY, F. A new ion-releasing restorative material. Amer. J. Dent., v. 12, p.S3, Nov. 1999. Special Issue.

34 - GOLCKMANN, E.; BECHMANN, H.; SIGUSCH, B. Fluoride, Calcium and Hidroxide release from the smart restorative material Ariston pHc. J. dent. Res., v.79, p.184, 2000. Special issue Abstract n.328. / Apresentado no $78^{\text {th }}$ General Session of the International Association for Dental Research, April 5-8, Washington, DC, 2000/ 
35 - GOMES, J.C.; CAVINA, D.A.; GOMES, O.M.M. Uma nova opção de material restaurador estético para dentes posteriores. Rev. gaúcha Odont., v.48, n.2, p.71-4, abr./jun. 2000.

36 - GRANDINI, R.; GIACHETTI, L. BERTINI, F. Resultados clínicos a corto plazo de um restaurados directo para posteriores. Signature Int., v.3, n.3, p.1-3, Mar. 1998.

37 - GRIFFIN, F.; DONLY, K. J.; ERICKSON, R. Caries inhibition by fluoride releasing liners. Amer. J. Dent., v.5, n.5, p.293-5, Sept. 1992.

38 - GWINNETT, J.A. et al. Comparison of three methods of critical evaluation of microleakage along restorative interfaces. J. prosth. Dent., v.74, n.6, p.575-85, Dec. 1995.

39 - HEINTZE, S.D. A new material concept for inhibiting the formation of secondary caries. Amer. J. Dent., v.12, p.S4-7, Nov. 1999. Special issue.

40 - HEMBREE JÚNIOR, J.H. Microleakage at the gengival margin of class II composite restorations with glass-ionomer liner. J. prosth. Dent.; v.61, n.1, p.28-30, Jan. 1989. 
41 - HILTON, J.T.; SCHWARTZ, S.R.; FERRACANE, J.L. Microleakage of four class II resin composite insertion techniques at intraoral temperature. Quintessence Int., v.28, n.2, p.135-44, Feb. 1997.

42 - HIROTA, K. et al. Thermal expansion coeficient of glass ionomer cements. J. dent. Res., v.67, p.114, 1988. Special issue Abstract n.225 A.

43 - HOLTAN, J.R. et al. Microlekage and marginal placement of glass-ionomer liners. Quintessence Int., v.21, n.2, p.117-22, Feb. 1990.

44 - KANCA, J. Posterior resins: microleakage below the cementoenamel junction. Quintessence Int., v.18, n.5, p.347-9, May 1987.

45 - KIDD, E.A.M. Microleakage: a review. J. Dent., v.4, n.5, p.199206, Sept. 1976.

46 - KIELBASSA, A.M.; MÜLLER, U.; GARCÍA-GODOY, F. In situ study on the caries-preventive effects of fluoride-releasing materials. Amer. J. Dent., v. 12, p.S13-4, Nov. 1999. Special issue. 
47 - KIELBASSA, A.M. et al. Influence of fluoride-relesing restorative materials on in situ induced demineralization. J. dent. Res., v.79, 2000. Special issue Abstract n.3743. / Apresentado no 78 th General Session of the International Association for Dental Research, April 5-8, Washington, DC, 2000/

48 - KRAMER, N. et al. Calicium release of a new "smart" resin composite. J. dent. Res., v.79, p.162 2000. Special issue Abstract n.152. / Apresentado no $78^{\text {th }}$ General Session of the International Association for Dental Research, April 5-8, Washington, DC, 2000/

49 - LIM, C.C.; NEO, J.; YAP, A. The influence of finishing time on the marginal seal of a resin-modified glass-ionomer and polyacidmodified resin composite. J. oral Rehab., v.26, n.1, p.48-52, Jan. 1999.

50 - MARTIN, F.F.; BRYANT, R.W. Acid etching of enamel cavity walls. Aust. dent. J., v.29, n.5, p.308-14, Oct. 1984.

51 - MATHIS, R.S. et al. Marginal leakage in class V composite resin restorations with glass ionomer liners in vitro. J. prosth. Dent., v.63, n.5, p.522-5, May 1990. 
52 - MILLER, M.B. et al. Effect of restorative materials on microleakage of class II composites. J. Esth. Dent., v.8, n.3, p.107-13, May 1996.

53 - NAVARRO, M.F.L.; PASCOTTO, R.C. Cimento de ionômero de vidro. In: . Cimento de ionômero de vidro. São Paulo, Artes Médicas, 1998. Cap.1, p.1-24.

54 - OLIVEIRA, A.H. Avaliação da microinfiltração e da ação anticariogênica em restaurações com resina composta associada a outros materiais. Bauru, 1999. 135p. Tese (Doutorado) - Faculdade de Odontologia de Bauru. Universidade de São Paulo.

55 - PALMER, D.S.; BARCO, M.T.; BILLY, E.J. Temperature extremes produced orally by hot and colds liquids. J. prosth. Dent., v.67, n.3, p. 325-7, May 1992.

56 - PATRI, C. Early marginal microleakage in class II resin composite restoration. Dent. Mat., v.5, n.11, p.392-8, Nov. 1989. 
57 - PIN, M.L.G. Avaliação da infiltração marginal em restaurações classe II modificadas, confeccionadas com um cimento de ionômero de vidro convencional, dois cimentos de ionômero de vidro modificado por resina e uma resina composta modificado por poliácidos: estudo in vitro. Bauru, 1997. 124p. Dissertação (Mestrado) - Faculdade de Odontologia de Bauru, Universidade de São Paulo.

58 - PIRES, L.A.G.; PACHECO, J.F.M. Uma nova alternativa restauradora direta de cor branca para dentes posteriores. Rev. Ass. paul. cirurg. Dent., v.53, n.6, p.499-504, nov./dez. 1999.

59 - RETIEF, D.H. Standardizing laboratory adhesion test. Amer. J. Dent., v.4, n.5, p.231-6, Oct. 1991.

60 - RETIEF, D.H.; Mc CAGHREN, R. A.; RUSSEL, C.M. Microleakage of Vitrebond/P-50 class II restorations. Amer. J. Dent., v.5, n.3, p.130-2, June 1992.

61 - RETIEF, D.H.; MANDRAS, R.S.; RUSSEL, C.M. Shear bond strength required to prevent microleakage at the dentin/restoration interface. Amer. J. Dent., v.3, n.3, p.11925, May 1994. 
62 - RIGSBY, D.F. et al. Effect of axial load and temperature cycling on microleakage of resin restorations. Amer. J Dent., v.5, n.3, p.155-9, May 1992.

63 - ROSSOMANDO, K.J.; WENDT JUNIOR, S.L. Thermocycling and dwell times in microleakage evaluation for bonded restorations. Dent. Mat., v.11, n.1, p.47 -51, Jan. 1995.

64 - SALLES, V. Avaliação in vitro da influência de dois adesivos dentinários na infiltração marginal de restaurações realizadas com um cimento de ionômero de vidro modificado por resina e uma resina composta modificado por poliácidos. Bauru, 1997. 108p. Dissertação (Mestrado) Faculdade de Odontologia de Bauru. Universidade de São Paulo.

65 - SCHIFFNER, U. Inhibition of enamel and root dentin demineralization by Ariston pHc: an artificial mouth study. Amer. J. Dent., v. 12, p.S10-2, Nov. 1999. Special Issue.

66 - SCHWATRZ, J.L.; ANDERSON, M.H.; PELLEU JR., G.B. Reducing microleakage with the glass-ionomer/resin sandwich technique. Oper. Dent., v.15, n.5, p.186-92, Sept./Oct. 1990. 
67 - SEGURA, A.; DONLY, K. J.; STRATMANN, R.G. Enamel remineralization on theeth adjacent to class II glass ionomer restorations. Amer. J. Dent., v.10, n.2, p.247-50, Apr. 1997.

68 - SHIDU, S.K.; WATSON, T.F. Resin-modified glass ionomer materials - a status report for the American Journal of Dentistry. Amer. J. Dent. v.8, n.1, p.59-67, Feb. 1995.

69 - SILVA E SOUZA JÚNIOR, M.H. et al. Avaliação da infiltração marginal em esmalte e cemento em cavidades classe II MOD restauradas com cinco sistemas adesivos. Rev. Fac. Odont. USP, v.5, n.2, p.140-5, jul./dez. 1991.

70 - SILVA E SOUZA JÚNIOR, M.H. et al. Resinas compostas em dentes posteriores: novos avanços. Disponível na Internet. http://www.universodonto.com.br/especialidades/dentistica/ artigo51.html. 10 ago. 1999.

71 - SNEDECOR, G.W.; COCHRAN, W.G. One-way classifications. Analysis of variance. In: Statistical Methods. 6.ed. Iowa, The Iowa State University Press Ames, c1967. Cap.10, p.258-98. 
72 - TAYLOR, M.J.; LYNCH, E. Microleakage. J. Dent., v.20, n.1, p.310, Jan./Feb. 1992.

73 - TRUMMLER, A.; MÜLLER, D.; WEISS, V. Clinical experience with a new tooth-colored dental restorative material (Ariston pHc) on primary theeth. Amer. J. Dent., v. 12, p.S15-6, Nov. 1999. Special Issue.

74 - VIEIRA, R.S. et al. Avaliação da infiltração marginal em restaurações de ionômero de vidro modificado por resinas compostas e resina composta modificada por poliácidos. Rev. bras. Odont., v.56, n.3, p.139-43, maio / jun. 1999.

75 - VITREMER TM - Ionômero de vidro de ativação tripla; perfil técnico do produto. s.1., 3M Dental Products Laboratory, 1994.

76 - VIVADENT SCHAAM. Scientific background: in-vitro studies. Disponivel na Internet. http://www.vivadent.com./restorat/ariston/vitro.htm 10 ago. 1999 
77 - WENDT, S.L.; McINNES, P.M.; DICKISON, G.L. The effect of thermocycling in microleakage analysis. Dent. Mat., v.8, n.3, p.181-4, May 1992.

78 - WILSON, A.D.; KENT., B.E. A new translucent cement for dentistry. The glass ionomer cement. Brit. dent. J., v.132, n.4, p.133-5, Feb. 1972.

79 - XU, X. et al. Artificial caries with fluoride-releasing and Nonfluoride-releasing restorative materials. J. dent. Res., v.79, p.248, 2000. Special issue Abstract n.1121. / Apresentado no $7^{\text {th }}$ General Session of the International Association for Dental Research, April 5-8, Washington, DC, 2000/

80 - YAP, A.U.J. Effects of storage, thermal and load cycling on a new reinforced glass-ionomer cement. J. oral Rehab., v.25, n.1, p.40-4, Jan. 1998.

81 - ZAR, J.H. Multisample Hypotheses: The Analysis of Variance. In: Biostatistical Analysis. 3.ed. New Jersey, Prentice Hall, c1996. Cap.10, p.179- 210. 
Abstract 


\section{ABSTRACT}

\section{"In vitro evaluation of marginal microleakage in class II restorations, made with a glass ionomer cement modified through resin Vitremer, "semicondensable" composite resin Ariston pHc and "condensable" composite resin P-60".}

It was the purpose of this work to assess in vitro marginal microleakage in class II restorations, made with a glass ionomer cement modified through resin Vitremer, "semicondensable" composite resin Ariston pHc and "condensable" composite resin P-60, pretending to verify the influence of thermocycling upon these materials, as well as of the performance of two methods for dye penetration analysis. Thus, 60 premolars received proximal class II cavities, with cervical wall situated above cement/enamel junction. The specimens were divided in three groups with 20 teeth each. Group I was restored with Vitremer, Group II with Ariston pHc and Group III with P-60. Following restoration, specimens were stored in plastic containers with deionized water for 24 hours under $37^{\circ} \mathrm{C}$. After this time period restorations were finished and polished. While half the group suffered a thermocycling process with 500 cycles under temperatures of $5^{\circ} \mathrm{C}$ and $55^{\circ} \mathrm{C}$, in baths of 15 seconds each, the other half remained stored in plastic 
containers with deionized water under $37^{\circ} \mathrm{C}$. After testing period, all specimens have been immersed into a $0.5 \%$ basic fuchsin solution for 24 hours under $37^{\circ} \mathrm{C}$, being next thoroughly washed in running water for 24 hours. For microleakage analysis, teeth were embedded in autopolimerizing plastic resin and sectioned in a mesiodistal sense, each tooth suffering a mean of four sections. For each section two images were obtained for the analysis through a software called Imagetools. Results have been examined through a Variance Analysis statistical test through two criteria (2-way ANOVA) and Tukey test for multiple comparisons between materials, at a 5\% significance level. Results showed that all tested groups presented marginal microleakage, glass ionomer cement modified with resin Vitremer always presenting the best results, followed by "condensable" composite resin P-60 and coming last "semicondensable" composite resin Ariston pHc. There was no statiscally significant difference between the use and non-use of thermocycling for these materials. When methods for dye penetration analyses were assessed the method of maximum leakage seems to be the best one for detecting microleakage extension. 